\begin{tabular}{|c|c|c|c|c|c|}
\hline 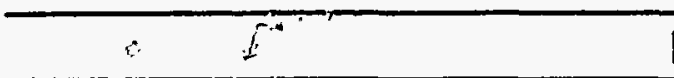 & \multicolumn{5}{|c|}{ DISTRIBUTION SHEET } \\
\hline \multirow{2}{*}{$\begin{array}{l}\text { To } \\
\text { Distribution }\end{array}$} & \multirow{2}{*}{\multicolumn{2}{|c|}{$\begin{array}{l}\text { From } \\
\text { SNF Project }\end{array}$}} & & \multicolumn{2}{|c|}{ Page 1 of 1} \\
\hline & & & & \multicolumn{2}{|c|}{$\begin{array}{l}\text { Date } \\
\text { December 28, } 1994\end{array}$} \\
\hline \multicolumn{4}{|l|}{ Project Title/Work Order } & \multicolumn{2}{|c|}{ EDT No. 607233} \\
\hline \multicolumn{4}{|c|}{$\begin{array}{l}\text { Hanford Site Existing Irradiated Fuel Storage Facilities } \\
\text { Description }\end{array}$} & N No. $\quad \mathrm{N}$ & \\
\hline Name & MSIN & $\begin{array}{c}\text { Text } \\
\text { With All } \\
\text { Attach. }\end{array}$ & Text Only & $\begin{array}{l}\text { Attach./ } \\
\text { Appendix } \\
\text { Oniy }\end{array}$ & $\begin{array}{l}\text { EDT/ECN } \\
\text { Only }\end{array}$ \\
\hline $\begin{array}{l}\text { R. R. Ames } \\
\text { J. D. Anderson } \\
\text { J. K. Andrews } \\
\text { P. C. Berlin } \\
\text { S. S. Clark } \\
\text { R. G. Cowan } \\
\text { G. E. Culley } \\
\text { K. D. Daschke } \\
\text { S. A. Dawson } \\
\text { D. J. Deschane } \\
\text { J. O. Dittmer } \\
\text { M. B. Enghusen } \\
\text { H. A. Frier } \\
\text { B. J. Fuquay } \\
\text { R. G. Gant } \\
\text { W. J. Geuther } \\
\text { E. W. Gerber } \\
\text { J. C. Hamrick } \\
\text { D. E. Knowlton } \\
\text { J. L. Marshal1 } \\
\text { R. L. McCormack } \\
\text { D. E. McKenney } \\
\text { G. C. Mooers } \\
\text { M. A. Ortega } \\
\text { D. E. Plowman } \\
\text { J. M. Seay } \\
\text { R. T. Steele } \\
\text { R. E. Thornhil1 } \\
\text { G. D. Trenchard } \\
\text { J. E. Truax } \\
\text { H. H. Van Tuyl } \\
\text { M. J. Wiemers } \\
\text { W. L. Willis (20) } \\
\text { J. C. Homack } \\
\text { Central Filesi } 1 \\
\text { O.S.T.I. (2) } \\
\end{array}$ & $\begin{array}{l}\text { N3-13 } \\
\text { T3-04 } \\
\text { P7-25 } \\
\text { N3-13 } \\
\text { R3-81 } \\
\text { R3-86 } \\
\text { R3-86 } \\
\text { R3-85 } \\
\text { N1-40 } \\
\text { P8-24 } \\
\text { N1-40 } \\
\text { S6-18 } \\
X 0-36 \\
\text { R3-85 } \\
X 0-41 \\
N 3-13 \\
\text { R3-86 } \\
X 0-22 \\
\text { P7-35 } \\
\text { N2-02 } \\
\text { R3-86 } \\
N 3-10 \\
\text { R3-85 } \\
\text { T3-28 } \\
\text { N3-13 } \\
\text { P8-24 } \\
\text { P7-22 } \\
\text { P7-38 } \\
\text { R3-81 } \\
X 3-71 \\
\text { P7-22 } \\
\text { R3-86 } \\
\text { R3-86 } \\
\text { R3-85 } \\
\text { L8-04 } \\
\text { L8-07 }\end{array}$ & $\begin{array}{l}x \\
x \\
x \\
x \\
x \\
x \\
x \\
x \\
x \\
x \\
x \\
x \\
x \\
x \\
x \\
x \\
x \\
x \\
x \\
x \\
x \\
x \\
x \\
x \\
x \\
x \\
x \\
x \\
x \\
x \\
x \\
x \\
x \\
\end{array}$ & & . & \\
\hline
\end{tabular}




\section{DISCLAIMER}

Portions of this document may be illegible in electronic image products. Images are produced from the best available original document. 
2. To: (Receiving Organization)

3. From: (Originating Organization) Engineering Integration

4. Related EDT MO.:

Distribution

6. Cog. Engr.:

Spent Nuclear Fuels Project H. L. Will is

5. Proj./Prog./Dept./Div.:

8. Originator Remarks:

None

$N / A$

13. Permit/Permit Application No.: $N / A$

14. Required Response Date:

$N / A$

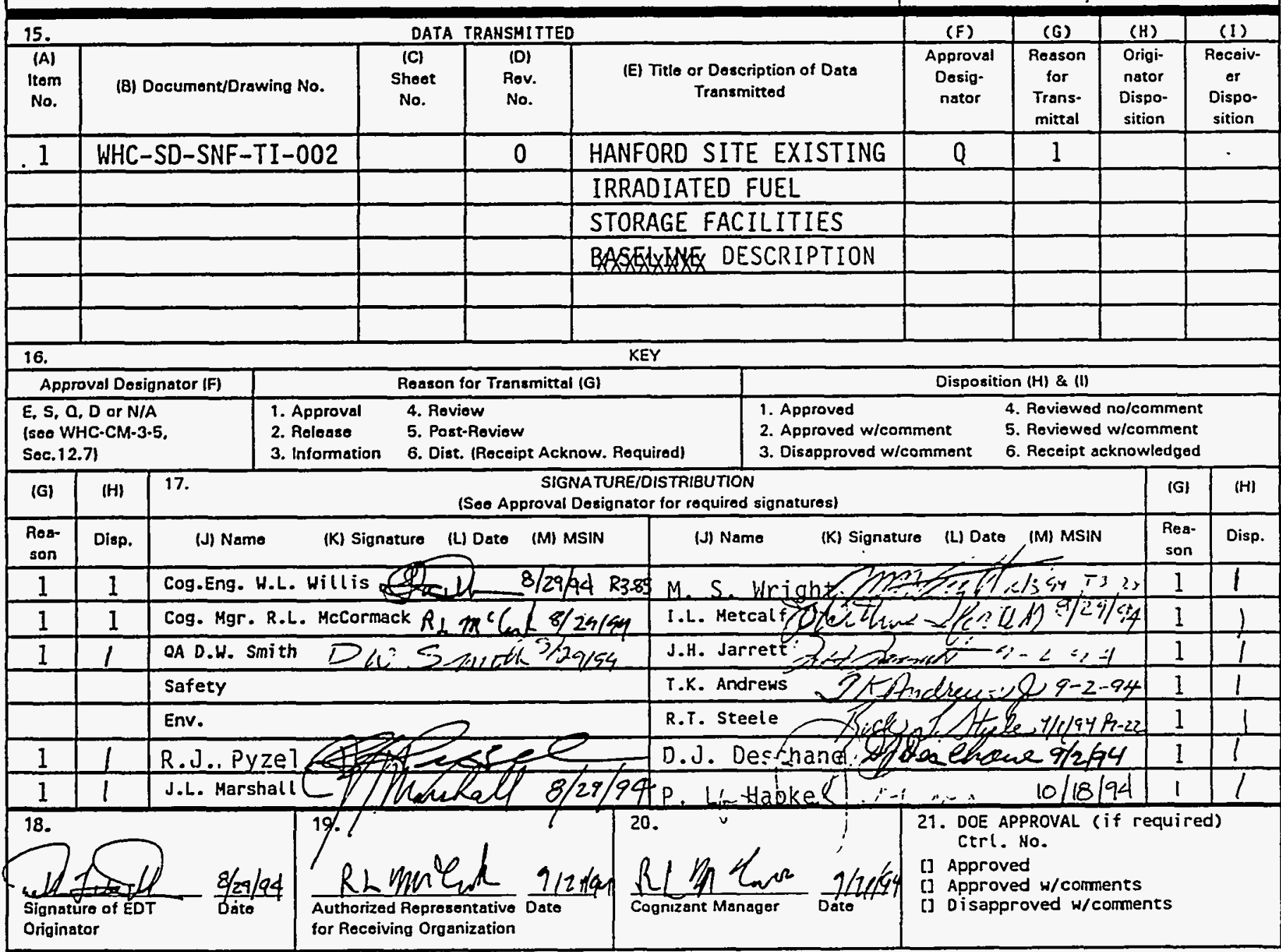

BD-7400-172-2 (04/94) GEF097 


\section{RELEASE AUTHORIZATION}

Document Number: WHC-SD-SNF-TI-002 REV. 0

Document Title: Hanford Site Existing Irradiated Fuel Storage

Facilities Description

Release Date: $\quad 01 / 11 / 95$

This document was reviewed following the procedures described in WHC-CM-3-4 and is:

APPROVED FOR PUBLIC RELEASE

WHC Information Release Administration Specialist:

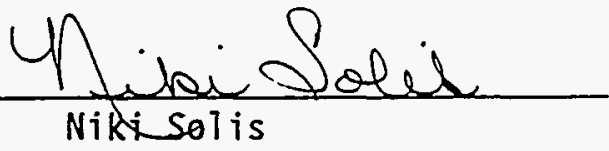

$01 / 11 / 95$

Nikisolis

TRADEMARK OISCLAIMER. Reference herein to any specific comercial product, process, or service by trade name, trademark, manufacturer, or otherwise, does not necessarily constitute or imply its endorsement, recommendation, or favoring by the United States Goverment or any agency thereof or its contractors or subcontractors.

This report has been reproduced from the best available copy. Available in paper copy and microfiche. Printed in the United States of America. Available to the U.S. Department of Energy and its contractors from:

U.S. Department of Energy

office of Scientific and Technical Information (OSTI)

P.O. Box 62

Oak Ridge, TH 37831

Telephone: (615) 576-8401

Available to the public from:

U.S. Department of Commerce

National Technical Information Service (NTIS)

5285 Port Royal Road

Springfield, VA 22161

Telephone: (703) 487-4650 


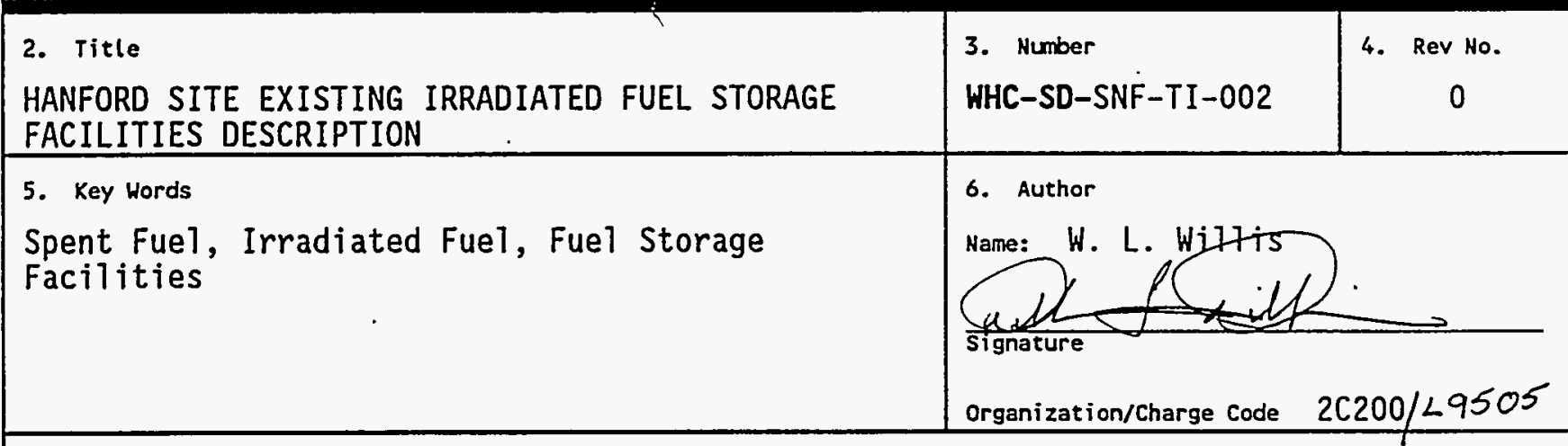

\section{Abstract}

This document describes facilities at the Hanford Site which are currently storing spent nuclear fuels. The descriptions provide a basis for the no-action

a)ternatives of ongoing and planned National Environmental Protection Act reviews.

The U.S. Department of Energy has identifed a path forward for removal of spent nuclear fuel from the 105-K Basins. The document was developed prior to the path forward decision and will be revised at a later date to reflect the path forward. 
WHC-SD-SNF-TI-002, Rev. 0

\title{
HANFORD SITE EXISTING IRRADIATED FUEL STORAGE FACILITIES DESCRIPTION
}

\author{
W. L. WILLIS \\ SPENT NUCLEAR FUEL PROJECT, 2C200
}

DECEMBER 1994

\section{DISCLAIMER}

This report was prepared as an account of work sponsored by an agency of the United States Government. Neither the United States Government nor any agency thereof, nor any of their employees, makes any warranty, express or implied, or assumes any legal liability or responsibility for the accuracy, completeness, or usefulness of any information, apparatus, product, or process disclosed, or represents that its use would not infringe privately owned rights. Reference herein to any specific commercial product, process, or service by trade name, trademark, manufacturer, or otherwise does not necessarily constitute or imply its endorsement, recommendation, or favoring by the United States Government or any agency thereof. The views and opinions of authors expressed herein do not necessarily state or reflect those of the United States Government or any agency thereof. 
WHC-SD-SNF-TI-002, Rev. 0

This page intentionally left blank. 
1.0 INTRODUCTION $\ldots \ldots \ldots \ldots \ldots \ldots \ldots \ldots \ldots \ldots \ldots \ldots \ldots \ldots \ldots \ldots \ldots \ldots$

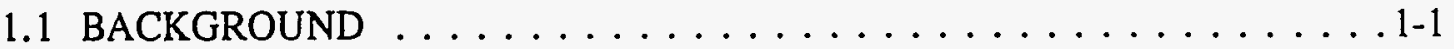

1.2 PURPOSE AND NEED $\ldots \ldots \ldots \ldots \ldots \ldots \ldots \ldots \ldots \ldots \ldots \ldots \ldots \ldots$

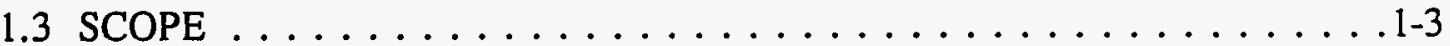

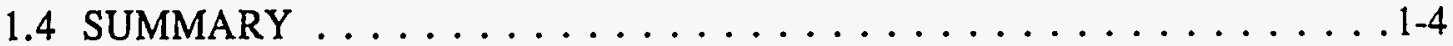

2.0 DESCRIPTION OF FUEL $\ldots \ldots \ldots \ldots \ldots \ldots \ldots \ldots \ldots \ldots \ldots \ldots \ldots .2-1$

2.1 DEFENSE PRODUCTION REACTOR FUEL $\ldots \ldots \ldots \ldots \ldots \ldots \ldots .2-1$

2.1.1 N Reactor Fuel . . . . . . . . . . . . . . . . 2-1

2.1.2 Single-Pass Reactor Fuel . . . . . . . . . . . . . 2-3

2.2 SHIPPINGPORT PWR CORE II FUEL $\ldots \ldots \ldots \ldots \ldots \ldots \ldots \ldots . . \ldots \ldots$

2.3 FAST FLUX TEST FACILITY FUEL $\ldots \ldots \ldots \ldots \ldots \ldots \ldots \ldots \ldots$

2.4 MISCELLANEOUS FUEL $\ldots \ldots \ldots \ldots \ldots \ldots \ldots \ldots \ldots \ldots$

3.0 105-KE AND 105-KW FUEL STORAGE BASINS $\ldots \ldots \ldots \ldots \ldots \ldots$

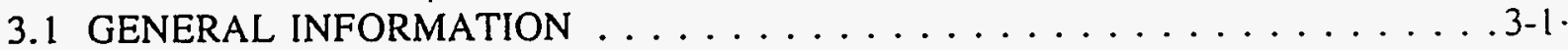

3.2 FACILITY TECHNICAL AND OPERATIONS DESCRIPTION . . . . . . 3-1

3.3 IRRADIATED FUEL STORAGE AT THE 105-KE

AND $105-\mathrm{KW}$ FUEL STORAGE BASINS $\ldots \ldots \ldots \ldots \ldots \ldots$ 3-7

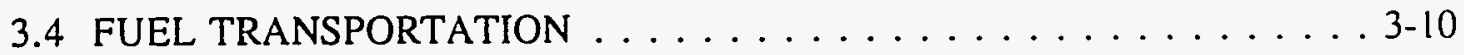

3.5 CONTINUED STORAGE AT THE 105-KE AND

105-KW FUEL STORAGE BASINS $\ldots \ldots \ldots \ldots \ldots \ldots$ 3-10

3.6 ESTIMATED STAFF SIZE AND OPERATIONAL COST $\ldots \ldots \ldots$. . $\ldots$ 3-12

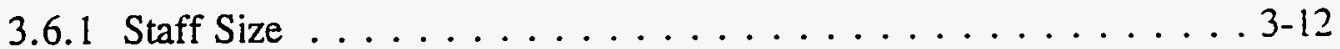

3.6.2 Operational Cost . . . . . . . . . . . . . 3-13

3.7 ESTIMATED OPERATIONAL DOSE COMMITMENT . . . . . . 3-14

3.8 ESTIMATED ROUTINE ENVIRONMENTAL RELEASES $\ldots \ldots \ldots \ldots$. . . 15

3.8.1 Radiological Airborne Emissions . . . . . . . . . . 3-15

3.8.2 Non-Radiological Airborne Emissions . . . . . . . . . . 3-16

3.8.3 105-KE and 105-KW Fuel Storage Basins Stack Information . . . 3-16

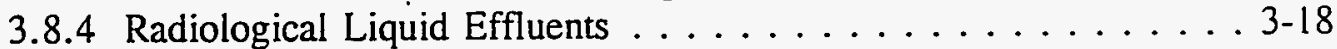

3.8.5 Non-Radiological Liquid Effluents . . . . . . . . . . 3-19

3.9 BOUNDING ACCIDENT SCENARIOS AND RELATED

ENVIRONMENTAL RELEASES . . . . . . . . . . . . . 3-19

3.9.1 Radiological Airborne Release Accident . . . . . . . . . 3-19

3.9.2 Non-Radiological Airborne Release . . . . . . . . . . 3-20

3.9.3 Radiological Liquid Release . . . . . . . . . . . . . . 3-20

3.9.4 Non-Radiological Liquid Release . . . . . . . . . . . . 3-21

4.0 FAST FLUX TEST FACILITY $\ldots \ldots \ldots \ldots \ldots \ldots \ldots \ldots \ldots \ldots \ldots \ldots$ 
4.1 GENERAL INFORMATION $\ldots \ldots \ldots \ldots \ldots \ldots \ldots \ldots \ldots . \ldots \ldots$

4.2 IRRADIATED FUEL STORAGE AT FFTF $\ldots \ldots \ldots \ldots \ldots \ldots \ldots$. $\ldots \ldots$

4.2 .1 Reactor Core . . . . . . . . . . . . . . . . .4-1

4.2.2 In-Vessel Storage . . . . . . . . . . . . . . . . 4-6

4.2 .3 Interim Decay Storage $\ldots \ldots \ldots \ldots \ldots \ldots \ldots . . .4 .6$

4.2 .4 Fuel Storage Facility . . . . . . . . . . . . . . . .7

4.2.5 Dry Storage at FFTF . . . . . . . . . . . . . . 4-7

4.3 FUEL TRANSPORTATION $\ldots \ldots \ldots \ldots \ldots \ldots \ldots \ldots \ldots .4 .8$

4.4 ESTIMATED STAFF SIZE AND OPERATIONAL COST $\ldots \ldots \ldots \ldots 4-8$

4.4.1 Estimated Staff Size $\ldots \ldots \ldots \ldots \ldots \ldots \ldots .4 .4 .4$

4.4.2 Estimated Operational Cost . . . . . . . . . . . . . 4-9

4.5 ESTIMATED OPERATIONAL DOSE COMMITMENT . . . . . . . . 4-9

4.6 ESTIMATED ROUTINE ENVIRONMENTAL RELEASES $\ldots \ldots \ldots$. 4-10

4.6.1 Radiological Airborne Emissions . . . . . . . . . . . 4-10

4.6.2 Non-Radiological Airborne Emissions . . . . . . . . . . 4-10

4.6.3 FFTF Stack Information . . . . . . . . . . . . 4-11

4.6.4 Radiological Liquid Effluents . . . . . . . . . . . . 4-11

4.6.5 Non-Radiological Liquid Effluents . . . . . . . . . . . 4-11

4.7 BOUNDING ACCIDENT SCENARIOS AND

RELATED ENVIRONMENTAL RELEASES . . . . . . . . . 4-11

4.7.1 Radiological Airborne Accident Scenario . . . . . . . . . 4-12

4.7.2 Non-Radiological Airborne Accident Scenario . . . . . . . . 4-12

4.7.3 Radiological and Non-Radiological Liquid Accident Scenarios . . 4-12

5.0 T PLANT $\ldots \ldots \ldots \ldots \ldots \ldots \ldots \ldots \ldots \ldots \ldots \ldots \ldots \ldots \ldots \ldots \ldots \ldots \ldots \ldots \ldots .1$

5.1 GENERAL INFORMATION $\ldots \ldots \ldots \ldots \ldots \ldots \ldots \ldots \ldots \ldots \ldots \ldots \ldots$

5.2 IRRADIATED SHIPPINGPORT PWR CORE II

FUEL STORAGE AT T PLANT $\ldots \ldots \ldots \ldots \ldots \ldots \ldots$. $\ldots \ldots$

5.3 DRY STORAGE AT T PLANT $\ldots \ldots \ldots \ldots \ldots \ldots \ldots \ldots \ldots$. $\ldots \ldots$

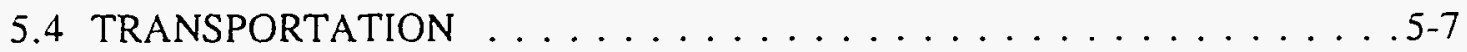

5.5 ESTIMATED STAFF SIZE AND OPERATIONAL COST $\ldots \ldots \ldots .5-7$

5.5.1 Estimated Staff Size . . . . . . . . . . . . . . . . . 5-7

5.5.2 Estimated Operational Cost . . . . . . . . . . . . 5-7

5.6 ESTIMATED OPERATIONAL DOSE COMMITMENT . . . . . . . 5-7

5.7 ESTIMATED ROUTINE ENVIRONMENTAL RELEASES $\ldots \ldots \ldots$. . 5-8

5.7.1 Radiological Airborne Emissions . . . . . . . . . . . . . 5-8

5.7.2 Non-Radiological Airborne Emissions . . . . . . . . . . . . 5-8

5.7 .3 T Plant Stack Information . . . . . . . . . . . . . . . . . 5-9

5.7.4 Radiological Liquid Effluents . . . . . . . . . . . . . . . 5-9

5.7.5 Non-Radiological Liquid Effluents . . . . . . . . . . . . . 5-9

5.8 BOUNDING ACCIDENT SCENARIOS AND

RELATED ENVIRONMENTAL RELEASES . . . . . . . . 5-10

5.8.1 Airborne Radiological Releases . . . . . . . . . . . . 5-10

5.8.2 Non-Radiological Airborne Releases . . . . . . . . . . 5-10 
5.8.3 Radiological Liquid Releases . . . . . . . . . . . 5-10

5.8.4 Non-Radiological Liquid Releases . . . . . . . . . . . 5-10

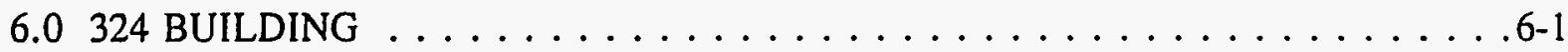

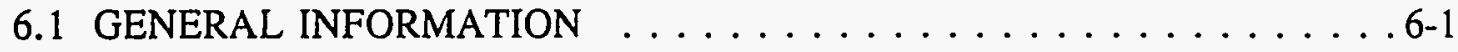

6.2 IRRADIATED FUEL STORAGE IN THE 324 BUILDING $\ldots \ldots \ldots \ldots 6-6$

6.2 .1 Airlock Cell . . . . . . . . . . . . . . 6-6

6.2 .2 B Cell $\ldots \ldots \ldots \ldots \ldots \ldots \ldots \ldots \ldots \ldots \ldots .6 \ldots .6 \ldots$

6.2 .3 D Cell . . . . . . . . . . . . . . . . . 6-8

6.3 TRANSPORTATION . . . . . . . . . . . . . . . 6-9

6.4 ESTIMATED STAFF SIZE AND OPERATIONAL COST . . . . . 6-9

6.4 .1 Estimated Staff Size . . . . . . . . . . . . . . . . . 6-9

6.4.2 Estimated Operational Cost . . . . . . . . . . . 6-10

6.5 ESTIMATED OPERATIONAL DOSE COMMITMENT . . . . . 6 6-10

6.6 ESTIMATED ROUTINE ENVIRONMENTAL RELEASES . . . . . 6-11

6.6.1 Radiological Airborne Emissions . . . . . . . . . . . 6-11

6.6.2 Non-Radiological Airborne Emissions . . . . . . . . 6-11

6.6.3 324 Building Stack Information . . . . . . . . . . . 6-12

6.6.4 Radiological Liquid Effluents . . . . . . . . . . . . 6-12

6.6.5 Non-Radiologícal Liquid Effluents . . . . . . . . . 6-12

6.7 BOUNDING ACCIDENT SCENARIO AND

RELATED ENVIRONMENTAL RELEASES . . . . . . . 6-12

6.7.1 Airborne Radiological Releases . . . . . . . . . . . 6-12

6.7.2 Non-Radiological Airborne Releases . . . . . . . . . . 6-13

6.7.3 Radiological Liquid Releases . . . . . . . . . . . . 6 6-14

6.7.4 Non-Radiological Liquid Releases . . . . . . . . . . 6-14

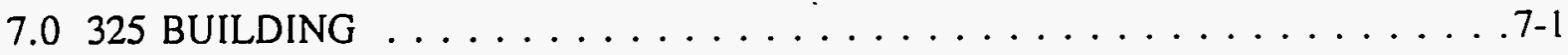

7.1 GENERAL INFORMATION $\ldots \ldots \ldots \ldots \ldots \ldots \ldots \ldots \ldots .7-1$

7.2 325-A HIGH-LEVEL RADIOCHEMISTRY FACILITY . . . . . 7-6

7.3 325-B SHIELDED ANALYTICAL LABORATORY . . . . . . 7-6

7.4 IRRADIATED FUEL STORAGE AT THE 325 BUILDING $\ldots \ldots \ldots .7$

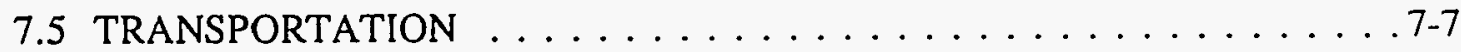

7.6 ESTIMATED STAFF SIZE AND OPERATIONAL COST $\ldots \ldots \ldots .7-7$

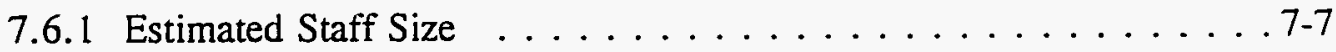

7.6.2 Estimated Operational Cost . . . . . . . . . . . 7-7

7.7 ESTIMATED OPERATIONAL DOSE COMMITMENT $\ldots \ldots \ldots \ldots \ldots 7-8$

7.8 ESTIMATED ROUTINE ENVIRONMENTAL RELEASES $\ldots \ldots \ldots \ldots 7-8$

7.8.1 Radiological Airborne Emissions . . . . . . . . . . . 7-8

7.8.2 Non-Radiological Airborne Emissions . . . . . . . . . . . . 7-9

7.8.3 325 Building Stack Information . . . . . . . . . . . . . 7-9

7.8.4 Radiological Liquid Effluents . . . . . . . . . . . . . . 7-9

7.8.5 Non-Radiological Liquid Effluents . . . . . . . . . . . . 7-9

7.9 BOUNDING ACCIDENT SCENARIO AND RELATED 


\section{WHC-SD-SNF-TI-002, Rev. 0}

ENVIRONMENTAL RELEASES $\ldots \ldots \ldots \ldots \ldots \ldots \ldots \ldots$ 7-10

7.9.1 Radiological Airborne Release . . . . . . . . . . . . 7-10

7.9.2 Non-Radiological Airborne Release . . . . . . . . . . . 7-11

7.9.3 Radiological and Non-Radiological Liquid Releases . . . . . . 7-11

8.0327 BUILDING . . . . . . . . . . . . . . . . . . . .

8.1 GENERAL INFORMATION $\ldots \ldots \ldots \ldots \ldots \ldots \ldots . \ldots \ldots$

8.2 IRRADIATED FUEL STORAGE AT THE 327 BUILDING $\ldots \ldots \ldots \ldots$. . . . .

8.3 ESTIMATED STAFF SIZE AND OPERATIONAL COST $\ldots \ldots \ldots .88$

8.3.1 Estimated Staff Size $\ldots \ldots \ldots \ldots \ldots \ldots \ldots . . . . .6$

8.3.2 Estimated Operational Cost . . . . . . . . . . . . 8-8

8.4 ESTIMATED OPERATIONAL DOSE COMMITMENT . . . . . . . . . 8-8

8.5 ESTIMATED ROUTINE ENVIRONMENTAL RELEASES $\ldots . . . . .8 .8-9$

8.5.1 Radiological Airborne Emissions . . . . . . . . . . . . . . . 8-9

8.5.2 Non-Radiological Airborne Emissions . . . . . . . . . . . . . . 8-9

8.5 .3327 Building Stack Information . . . . . . . . . . . . . . . 8-9

8.5.4 Radiological Liquid Effluents . . . . . . . . . . . 8-10

8.5.5 Non-Radiological Liquid Effluents . . . . . . . . . . 8-10

8.6 BOUNDING ACCIDENT SCENARIO AND RELATED

ENVIRONMENTAL RELEASES . . . . . . . . . . . 8-10

8.6.1 Radiological Airborne Release . . . . . . . . . . . 8-10

8.6.2 Non-Radiological Airborne Releases . . . . . . . . 8-10

8.6.3 Radiological Liquid Releases . . . . . . . . . . . 8-12

8.6.4 Non-Radiological Liquid Releases . . . . . . . . . 8-12

9.0308 BUILDING . . . . . . . . . . . . . . . . . . . . . .9-1

9.1 GENERAL INFORMATION . . . . . . . . . . . . .9-1

9.2 IRRADIATED TRIGA FUEL STORAGE AT THE 308 BUILDING . . . . 9-6

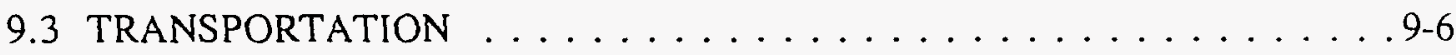

9.4 ESTIMATED STAFF SIZE AND OPERATIONAL COST $\ldots \ldots \ldots .9-7$

9.4.1 Estimated Staff Size . . . . . . . . . . . . . . . . . . 9-7

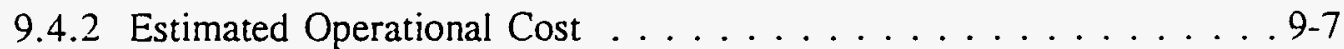

9.5 ESTIMATED OPERATIONAL DOSE COMMITMENT . . . . . . 9-7

9.6 ESTIMATED ROUTINE ENVIRONMENTAL RELEASES $\ldots . . \ldots .99-7$

9.6.1 Radiological Airborne Emissions . . . . . . . . . . . . . 9-7

9.6.2 Non-Radiological Airborne Emissions . . . . . . . . . . . 9-8

9.6.3 308 Building Stack Information . . . . . . . . . . . . 9-8

9.6.4 Radiological and Non-Radiological Liquid Effluents . . . . . . . 9-9

9.7 BOUNDING ACCIDENT SCENARIO AND

RELATED ENVIRONMENTAL RELEASES . . . . . . . . . . . . . 9-9

9.7.1 Radiological Airborne Releases . . . . . . . . . . . . . . 9-9

9.7.2 Non-Radiological Airborne Releases . . . . . . . . . . . . . 9-9

9.7.3 Radiological Liquid Releases . . . . . . . . . . . . . . . 9-9

9.7.4 Non-Radiological Liquid Releases . . . . . . . . . . . . 9-9 
10.0 200 WEST AREA BURIAL GROUNDS REACTOR IRRADIATED

NUCLEAR MATERIALS STORAGE FACILITIES $\ldots \ldots \ldots \ldots$. . .

10.1 GENERAL INFORMATION $\ldots \ldots \ldots \ldots \ldots \ldots \ldots \ldots \ldots \ldots \ldots$

10.2 RINM STORED AS REMOTE-HANDLED TRU WASTE IN THE 200 WEST AREA BURIAL GROUNDS $\ldots \ldots \ldots \ldots$ 10-5

10.3 ESTIMATED STAFF SIZE AND OPERATIONAL COST $\ldots \ldots \ldots 10-5$

10.3.1 Estimated Staff Size . . . . . . . . . . . . . . . 10-5

10.3.2 Estimated Operational Cost . . . . . . . . . . . . 10-5

10.4 ESTIMATED OPERATIONAL DOSE COMMITMENT $\ldots \ldots \ldots$ 10-6

10.5 ESTIMATED ENVIRONMENTAL RELEASES $\ldots \ldots \ldots \ldots \ldots$ 10-6

10.5.1 Radiological Airborne Emissions . . . . . . . . . . 10-6

10.5.2 Non-Radiological Airborne emissions . . . . . . . . 10-6

10.5.3 200 West Area Burial Ground Stack Information . . . . . . 10 10 6

10.5.4 Radiological Liquid Effluents . . . . . . . . . . 10-6

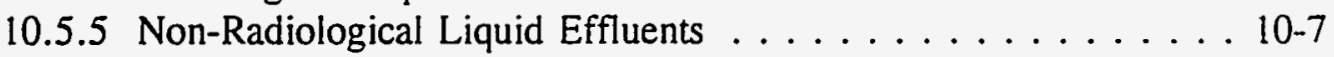

10.6 BOUNDING ACCIDENT SCENARIO AND

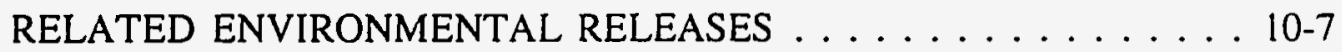

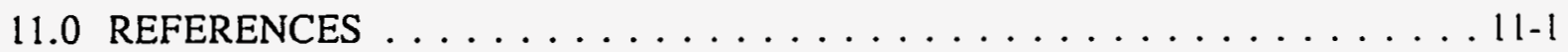




\section{WHC-SD-SNF-TI-002, Rev. 0}

\section{LIST OF TABLES}

3-1 105-KE Fuel Storage Basin Radiological Airborne Emissions $\ldots \ldots$. . . . 3-17

3-2 105-KW Fuel Storage Basin Radiological Airborne Emissions . . . . . . . . . 3-17

3-3 Radiological Liquid Effluents from 105-K . . . . . . . . . . . . . 3-19

4-1 Radiological Airborne Emissions from FFTF . . . . . . . . . . 4-10

5-1 Radiological Airborne Emissions at T Plant $\ldots \ldots \ldots \ldots \ldots$ 5-8

5-2 Accident Release Fractions for Damaged Module . . . . . . . . . . . 5-11

6-1 Radionuclide Releases from 324 Building $\ldots \ldots \ldots \ldots$. . . . . . . .

6-2 324 Building Non-Radiological Accident Consequence . . . . . . . . . . . 6-14

7-1 325 Building Airborne Radionuclide Releases . . . . . . . . . . 7-9

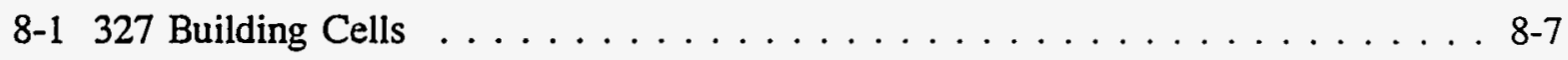

8-2 327 Building Airborne Radionuclide Releases $\ldots \ldots$. . . . . . . . 8-9

8-3 327 Building Radionuclide Inventory and Release Fraction $\ldots \ldots \ldots$. . . . .

8-4 327 Building Storage Pool Water Quality $\ldots \ldots \ldots \ldots \ldots \ldots \ldots$ 8-12

9-1 308 Building Airborne TRIGA Storage Basin Radionuclide Releases . . . . . . . 9-8

9-2 308 Building TRIGA Fuel Storage Basin Analysis $\ldots \ldots \ldots \ldots \ldots$. . . . . .

10-1 Release Fractions for Low-Level Waste Burial Ground Accident Scenarios . . . 10-7

10-2 Low-Level Burial Ground EBR-II Cask Inventories and Release Quantities . . . 10-8

10-3 Results of GENII Calculations for Maximum TRU Inventory Case for Accident Scenarios 1 and $2 \ldots \ldots \ldots \ldots \ldots$. . . . . . . . . . . . .

10-4 Results of GENII Calculations for Maximum Fission Product Inventory Case for Accident Scenarios 1 and $2 \ldots \ldots \ldots \ldots$ 10-10 
WHC-SD-SNF-TI-002, Rev. 0

This page intentionally left blank. 
WHC-SD-SNF-TI-002, Rev. 0

\section{LIST OF TERMS}

$\begin{array}{ll}\text { DOE } & \text { U.S. Department of Energy } \\ \text { EIS } & \text { environmental impact statement } \\ \text { FFTF } & \text { Fast Flux Test Facility } \\ \text { FSF } & \text { fuel storage facility } \\ \text { HEPA } & \text { high-efficiency particulate air } \\ \text { IDLH } & \text { immediately dangerous to life and health } \\ \text { IDS } & \text { interim decay storage } \\ \text { IEM } & \text { interim examination and maintenance } \\ \text { IVS } & \text { in-vessel storage } \\ \text { LLI } & \text { large lower intestine } \\ \text { PNL } & \text { Pacific Northwest Laboratory } \\ \text { PUREX } & \text { Plutonium Uranium Extraction (Plant) } \\ \text { PWR } & \text { pressurized water reactor } \\ \text { NEPA } & \text { national environmental policy act } \\ \text { NRF } & \text { Neutron Radiography Facility } \\ \text { RINM } & \text { reactor irradiated nuclear material } \\ \text { SAR } & \text { safety analysis report } \\ \text { SERF } & \text { Special Environmental Radiometallurgy Facility } \\ \text { Shippingport PWR } & \text { U.S. Department of Energy, Division of Naval Operations, } \\ \text { Core II } & \text { Shippingport Pressurized Water Reactor Core II } \\ \text { SNF } & \text { spent nuclear fuel } \\ \text { SPR } & \text { single-pass reactor } \\ \text { TRIGA } & \text { Test, Research, Isotope, General Atomics (reactor) } \\ \text { TRU } & \text { transuranic } \\ \text { TWA } & \text { time-weighted average } \\ & \end{array}$


WHC-SD-SNF-TI-002, Rev. 0

This page intentionally left blank. 


\subsection{INTRODUCTION}

\subsection{BACKGROUND}

Various types of irradiated fuel are currently stored at the U.S. Department of Energy's (DOE) Hanford Site (see Figure 1-1). Most of this fuel was irradiated at the Hanford Site plutonium production reactors for national defense purposes; some was irradiated to support research. A small amount of fuel was irradiated offsite at other Federal or commercial facilities and shipped to the Hanford Site for storage, characterization, and/or processing.

After 1967, The Plutonium Uranium Extraction (PUREX) Plant was the only facility available to process irradiated nuclear fuel at the Hanford Site. The PUREX and Uranium Oxide Plant Facilities Environmental Impact Statement (DOE-RL 1983) enabled resumption of PUREX Plant processing activities after an extended standby period (DOE-RL 1983). Operations were to be resumed to meet projected needs in the nuclear defense and research and development programs.

In October 1990, the U.S. Secretary of Energy, in a joint news conference with U.S. Senator Mark Hatfield (from Oregon), announced that DOE would prepare an environmental impact statement (EIS) to assess the potential effects of any future restart of the PUREX Plant for use in processing irradiated reactor fuel. Potential impacts from other available fuel management and disposal options were to be evaluated in the planned EIS as well. However, in October 1992, the U.S. Secretary of Energy directed permanent shutdown of the PUREX Plant; a decision which removed the PUREX Plant from consideration in the proposed EIS (Hunter 1993).

The DOE subsequently delayed the proposed EIS to address Hanford fuel management until programmatic spent nuclear fuel (SNF) management decisions were finalized by the DOE Programmatic SNF Management and Idaho National Engineering Laboratory Environmental Restoration and Waste Management Programs EIS (Programmatic EIS) Record of Decision. The requirement for the Programmatic EIS stemmed from a June 1993 U.S. District Court for the District of Idaho Order ruling and a September 1993 modification of the court ruling. The modification includes a commitment for issuance of the final Programmatic EIS and the Record of Decision by June 1995.

The Programmatic EIS will identify which DOE sites will manage various DOE owned SNF inventories until ultimate disposition of those inventories are identified. Sitespecific National Environmental Policy Act (NEPA) reviews, such as the proposed EIS to address Hanford fuel management, will provide NEPA coverage necessary to implement the Programmatic EIS Record of Decision at the affected sites. Additional interim action NEPA 
WHC-SD-SNF-TI-002, Rev. 0

Figure 1-1. Hanford Site Map. 
WHC-SD-SNF-TI-002, Rev. 0

reviews may be completed, where permissible under NEPA, to assure safe SNF management until issuance of the Programmatic EIS Record of Decision.

Alternatives within each of the NEPA reviews include use of existing storage facilities as a "no-action" alternative. The information in this document was developed for use in developing the "no-action" alternative for the NEPA review activities.

The DOE is in the process of evaluating some irradiated fuel materials at Hanford to identify whether these materials should be managed as spent nuclear fuel or within other DOE material classifications, per approved definitions. This document will be revised, as necessary, at a later date to reflect: the selected path forward for $105-\mathrm{K}$ fuel storage basins fuel removal; and the final DOE irradiated fuels material classifications.

\subsection{PURPOSE AND NEED}

The purpose of this document is to describe the existing storage facilities at the Hanford Site for use in developing the "no-action" alternative for programmatic and sitespecific NEPA reviews relating to Hanford SNF management. The information will be used as a basis for comparing the "no-action" alternative with other management alternatives.

\subsection{SCOPE}

This document describes a baseline of current irradiated fuel storage facilities at the Hanford Site. The baseline information on the facilities will include the following for each facility:

- Facility technical and operations descriptions

- Estimated staff size and operational cost

- Estimated operational dose commitment

- Estimated routine environmental releases

- Bounding accident scenario and related environmental releases.

Fuel and other materials that are included in the Programmatic EIS and will be included in site-specific NEPA reviews, pending irradiated fuel material reclassification, are described in "Hanford Spent Fuel Inventory Baseline" (WHC 1994c). The groups include:

- $\quad$ N Reactor and single-pass reactor (SPR) irradiated fuel currently stored at the 105-KE and 105-KW fuel storage basins and the PUREX Plant;

- Fast Flux Test Facility (FFTF) irradiated fuel currently stored in the 400 Area; 
- U.S. Department of Energy, Division of Naval Operations, Shippingport Pressurized Water Reactor Core II (Shippingport PWR Core II) irradiated fuel currently stored at $\mathrm{T}$ Plant;

- Miscellaneous irradiated fuel currently stored in the 300 Area $(324,325,327$, and 308 Buildings) and Reactor Irradiated Nuclear Materials (RINM) stored in the 200 West Area low-level burial ground (RINM in the burial grounds are currently managed as contact-handled and remote-handled transuranic [TRU] waste).

\subsection{SUMMARY}

Spent nuclear fuel is currently located at nine facilities at the Hanford Site (PUREX Plant is not considered in this study because it is planned that PUREX fuel will be relocated). The storage conditions at each facility varies based on the storage configuration and general condition of the fuel and the facility.

This document provides the technical information necessary to support development of the "no action" alternative for major NEPA review activities that cover Hanford Site SNF management, both programmatic and site-specific. 


\subsection{DESCRIPTION OF FUEL}

There are a variety of DOE-owned fuels stored at the Hanford Site including fuel from the defense production reactors (i.e., N Reactor and the SPRs), Shippingport PWR Core II, the FFTF reactor, and other reactors. These fuels are briefly described in the following sections. A detailed description is provided in WHC-SD-SNF-TI-001, Rev. 0 (WHC 1994c).

\subsection{DEFENSE PRODUCTION REACTOR FUEL}

Two types of fuel were used for defense production at the Hanford Site: N Reactor fuel and SPR fuel. The fuel is made of uranium metal with relatively low ${ }^{235} \mathrm{U}$ enrichment. The assemblies are much smaller than commercial reactor fuel assemblies and cylindrical in shape. The reactor exposures of the fuels are relatively lower than most commercial or research fuel reactor exposures.

Neither N Reactor fuel nor SPR fuel was designed for safe long-term storage; both fuel types include elements with cladding that are either known or suspected to be damaged.

\subsubsection{N Reactor Fuel}

There are over 100,000 irradiated N Reactor fuel assemblies at the Hanford Site containing 2,100 metric tons uranium (WHC 1994c). N Reactor fuel consists of assemblies made of two concentric uranium metal tubes, known as elements, that are coextruded into Zircaloy-2 cladding (Figure 2-1).

There are two basic preirradiation enrichments. Mark IV fuel elements have a preirradiation enrichment of 0.947 percent ${ }^{235} \mathrm{U}$ in both tubes, an average uranium mass of $22.7 \mathrm{~kg}(50 \mathrm{lb})$, an outside diameter of $6.1 \mathrm{~cm}(2.42 \mathrm{in}$.), and a length from 44 to $66 \mathrm{~cm}$ (17.4 to $26.1 \mathrm{in}$.). Mark IA fuel elements have a preirradiation enrichment of 1.25 percent ${ }^{235} \mathrm{U}$ in the outer tube and 0.947 percent ${ }^{235} \mathrm{U}$ in the inner tube, an average uranium mass of $16.3 \mathrm{~kg}(35.9 \mathrm{lb})$, an outside diameter of $6.1 \mathrm{~cm}(2.40 \mathrm{in}$.), and a length of 38 to $53 \mathrm{~cm}$ (14.9 to $20.9 \mathrm{in}$.). There is also a small amount of $\mathrm{N}$ Reactor fuel that has preirradiation enrichments in both the inner and outer tubes of 0.71 percent. $N$ Reactor fuel is divided into groups by exposure (i.e., weapon and fuel grade). 
WHC-SD-SNF-TI-002, Rev. 0

Figure 2-1. N Reactor Fuel.

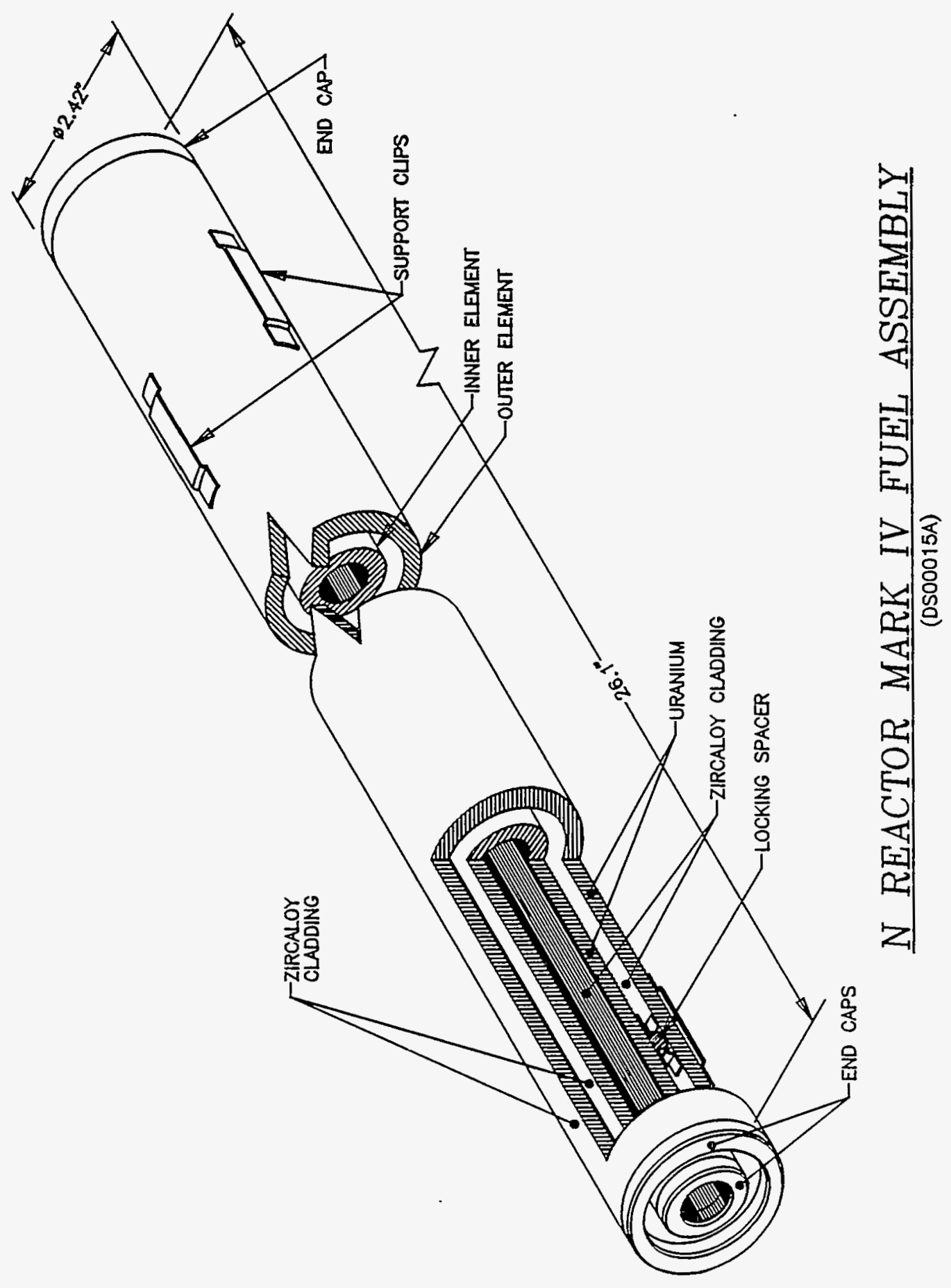


Weapon-grade plutonium is 6 percent ${ }^{240} \mathrm{Pu}$; fuel-grade plutonium is 12 percent ${ }^{240} \mathrm{Pu}$. The exposure (in megawatt days per metric ton uranium) and time since discharge from the reactor (i.e., time since last irradiation as of April 1994) are as follows:

Fuel ${ }^{240} \mathrm{Pu} \quad$ Mark IV exposure Mark IA exposure Time since discharge enrichment (\%) (MWd/t uranium) (Mwd/t uranium) (years)

12 2,268 2,720 13 to 23 6 907 1,089 7 to 8

Physical and chemical properties of $\mathrm{N}$ Reactor fuel, along with radionuclide composition, are discussed in detail in WHC-SD-SNF-TI-001, Rev. 0 (WHC 1994c). Nearly all of the inventory is stored at the $105-\mathrm{KE}$ and $105-\mathrm{KW}$ fuel storage basins in $100 \mathrm{~K}$ Area.

\subsubsection{Single-Pass Reactor Fuel}

There are approximately 1,000 irradiated SPR fuel elements at the Hanford Site containing 3.38 metric tons uranium (WHC 1994c). The majority of the fuel is stored in the PUREX storage basin. The remaining SPR fuel is stored in the 105-KE and 105-KW fuel storage basins. The fuel stored at PUREX will likely be transferred to the 105-KE fuel storage basin or the $105-\mathrm{KW}$ fuel storage basin before implementation of the irradiated fuel EIS record of decision. The SPR fuel consists of a machined uranium core that is sealed within and metallurgically bonded to an aluminum can. There are three designs for SPR fuel elements (1) solid core cylinders, (2) hollow core cylinders, and (3) tubes (see Figure 2-2). The lengths of the fuel elements range from approximately $12 \mathrm{~cm}(4.7$ in.) to $23 \mathrm{~cm}$ (9.0 in.). The diameters of most of the fuel elements vary from $3.45 \mathrm{~cm}(1.36 \mathrm{in}$.) to $3.63 \mathrm{~cm}$ (1.43 in.), with slight differences in the process tubes of different reactors. Some of the fuel elements for the $105-\mathrm{KE}$ and $105-\mathrm{KW}$ reactors had $5.1-\mathrm{cm}$ (2-in.) diameters.

The SPR fuel was irradiated in one or more of the eight SPRs operated at the Hanford Site from 1944 to 1971 . The SPR fuel at PUREX is significantly different from the SPR fuel at the 105-KE and 105-KW fuel storage basins. At the 105-KE and 105-KW fuel storage basins, typical SPR fuel enrichment ranged from 0.71 percent to 1.25 percent ${ }^{235} \mathrm{U}$, and was irradiated less than $1,000 \mathrm{Mwd} / \mathrm{t}$ uranium. PUREX SPR fuel was highly depleted (0.064 percent $\left.{ }^{235} \mathrm{U}\right)$, and was irradiated 3,031 Mwd/t uranium. The PUREX SPR fuel has a 26-percent ${ }^{240} \mathrm{Pu}$ content. The PUREX SPR fuel was discharged from the reactor before May 1968, and therefore has been in storage at least 26 years since reactor discharge. The last SPR ceased operation in 1971, and the time since discharge for the 105-KE and $105-\mathrm{KW}$ fuel storage basin SPR is at least 23 years. Physical and chemical properties of SPR fuel, along with radionuclide composition, are discussed in detail in WHC-SD-SNF-TI-001, Rev. 0 (WHC 1994c). 
WHC-SD-SNF-TI-002, Rev. 0

Figure 2-2. Single-Pass Reactor Fuel.

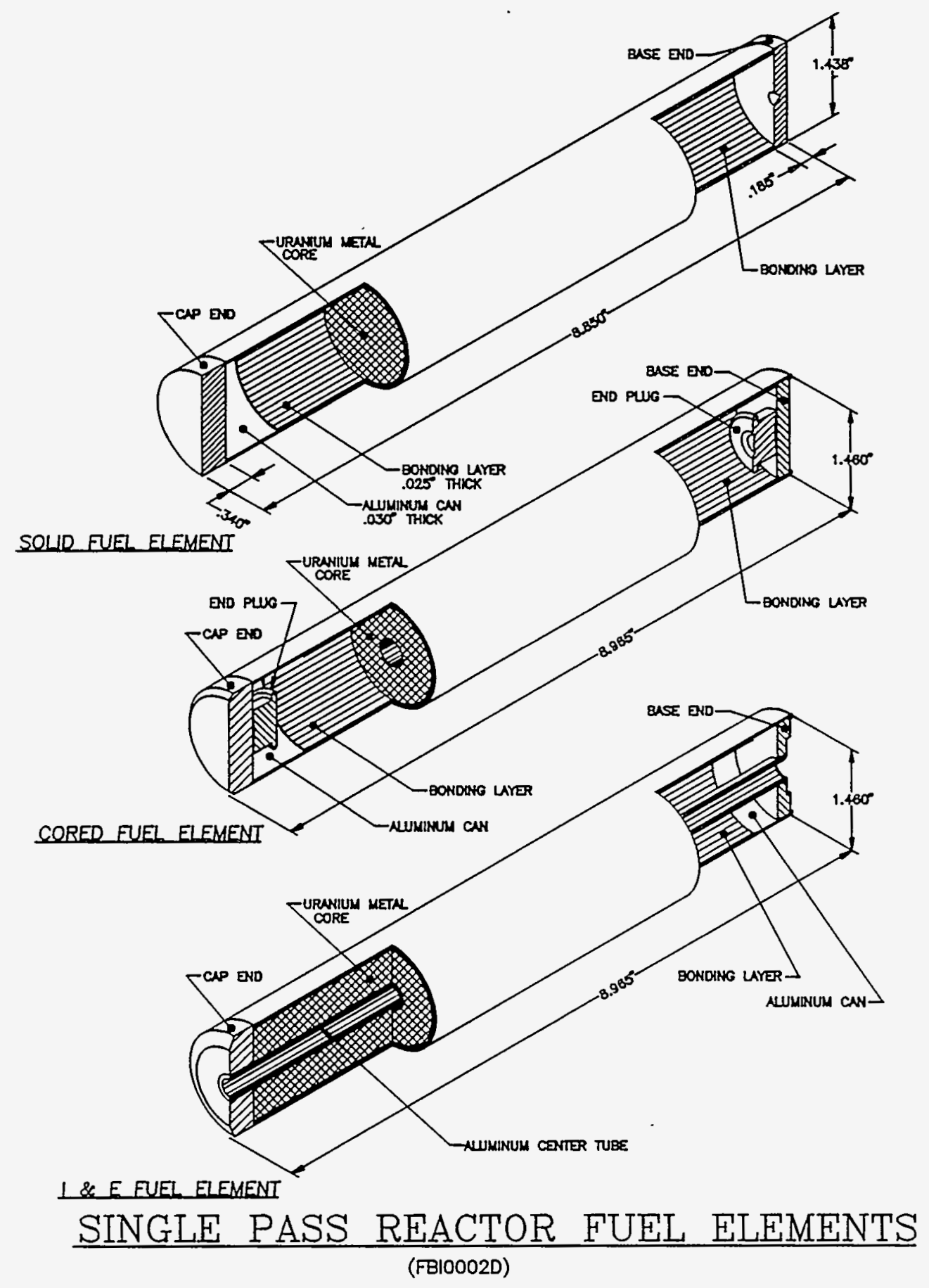


WHC-SD-SNF-TI-002, Rev. 0

\subsection{SHIPPINGPORT PWR CORE II FUEL}

There are 72 irradiated blanket assemblies from the Shippingport PWR Core II containing 15.66 metric tons uranium in the form of uranium dioxide $\left(\mathrm{UO}_{2}\right)$ and 0.12 metric tons plutonium (WHC 1994c). The assemblies are stored in the water cell (storage pool) at the T Plant 221-T Canyon Building in the 200 Area of the Hanford Site.

The 72 standard blanket assemblies are $3.6 \mathrm{~m}$ (142.3 in.) long and have a 19-cm (7.5-in.) square cross-section (Atherton et al. 1968). The blanket assemblies were originally manufactured with natural uranium. An assembly is shown schematically in Figure 2-3. The exposure during Shippingport PWR Core II irradiation was $16,200 \mathrm{Mwd} / \mathrm{t}$ uranium. The assemblies contain three basic sections which are bolted together: (1) an extended fuel cluster, (2) top extension bracket, and (3) bottom extension bracket. Each assembly contains plates of $\mathrm{UO}_{2}$ and has a mass of approximately $536 \mathrm{~kg}(1,180 \mathrm{lb})$. Physical and chemical properties of Shippingport PWR Core II fuel, along with radionuclide composition, are discussed in detail in WHC-SD-SNF-TI-001, Rev. 0 (WHC 1994c).

\subsection{FAST FLUX TEST FACILITY FUEL}

Fuel from 329 fuel assemblies containing 8.6 metric tons uranium and 2.9 metric tons plutonium is in the fuel inventory from the FFTF. Twenty-seven of the assemblies have been dismantled (WHC 1994c). The FFTF assemblies are divided into three general categories: (1) driver fuel assemblies, (2) test driver fuel assemblies, and (3) test fuel assemblies.

The fuel used in the driver fuel assemblies and the test driver fuel assemblies is mixed uranium-plutonium oxide. The plutonium enrichment of the FFTF assemblies is expressed as weight percent plutonium of the total plutonium and uranium present $(w t \% \mathrm{Pu} /[\mathrm{Pu}+\mathrm{U}])$. A driver fuel assembly contains one of four different preirradiation plutonium enrichments. Natural uranium is used with the 22-percent and the 27-percent plutonium enrichments, while depleted uranium $\left(0.2\right.$ percent $\left.{ }^{235} \mathrm{U}\right)$ is used with the 29 -percent and 25 -percent plutonium enrichments.

The test fuel assemblies contain fuel with different compositions than the driver fuel assemblies, although a few also contain some driver fuel assembly fuel pins. The test fuel assembly fuel composition is predominately mixed plutonium-uranium oxides having plutonium enrichments between 18 to 33 percent and natural or depleted uranium. In addition to the mixed plutonium-uranium oxide fuels, a variety of other fuel types were used at FFTF including mixed plutonium-uranium oxides and carbides, uranium oxides and nitrides, and uranium-zirconium and uranium-plutonium-zirconium metals. Within this group of fuel types, the uranium content ranged from 0.2 to 89 percent and plutonium enrichments ranged from 18 to 33 percent, although uranium and plutonium content of each fuel type did not vary as widely. 
WHC-SD-SNF-TI-002, Rev. 0

Figure 2-3. Shippingport PWR Core II Fuel.

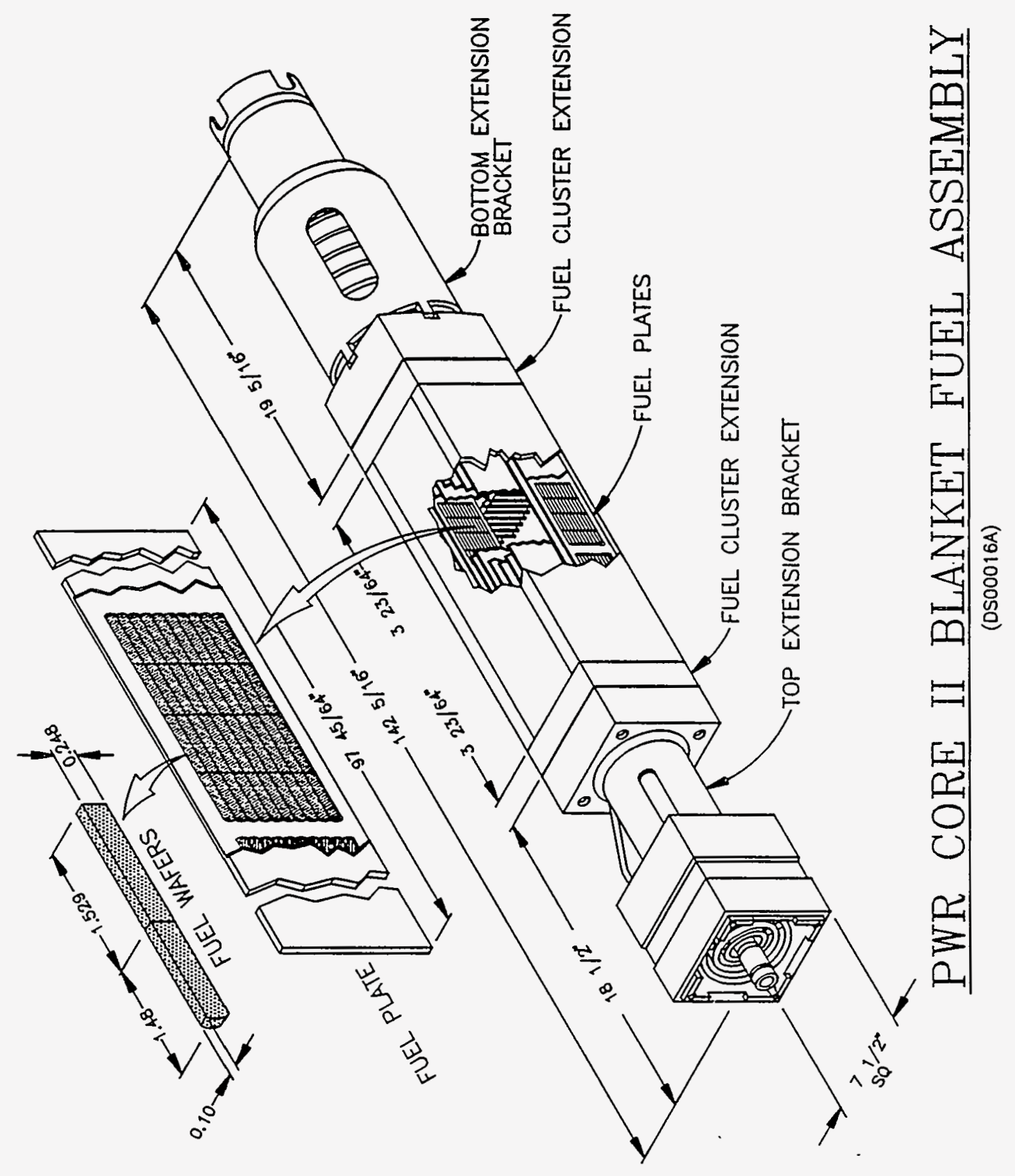


The exposure of fuels varied greatly in FFTF. Assemblies with exposures from nearly 0 to $200 \mathrm{Mwd} / \mathrm{kg}$ heavy metal are currently in storage, although most of the fuel was exposed from 60 to $90 \mathrm{Mwd} / \mathrm{kg}$ heavy metal. FFTF fuel assemblies have been discharged from irradiation in the reactor from the early 1980's through 1992.

Most of the FFTF stored fuel inventory is at the 400 Area of the Hanford Site. A small amount is stored at the 300 Area and at offsite locations. The fuel assemblies are $3.6 \mathrm{~m}$ (12 ft) long, $11.6 \mathrm{~cm}$ (4.575 in.) wide across the hexagon flats, $13.1 \mathrm{~cm}(5.16 \mathrm{in}$.) wide across the hexagon points, and has a mass of $173 \mathrm{~kg}(381 \mathrm{lb})$. The assembly is shown schematically in Figure 2-4. Details of the physical and chemical properties and a complete irradiation history of FFTF assemblies are discussed in WHC-SD-SNF-TI-001, Rev. 0 (WHC 1994c).

Most of the fuel pins from the disassembled assemblies are stored in Ident 69 containers. The Ident 69 container is one of a family of containers designed to hold FFTF partial assemblies and fuel pins. It is used for storage of irradiated assembly fuel or blanket pins in the fuel storage facility (FSF), interim examination and maintenance (IEM) cell, or as an inner container for a licensed radioactive transportation cask.

\subsection{MISCELLANEOUS FUEL}

There are 2.6 metric tons heavy metal held in a large variety of irradiated fuel stored at several different locations in the 300 Area and at the 200 West Area low-level burial grounds of the Hanford Site. Most of the fuel (2.3 metric tons heavy metal) is typical of end-of-life commercial pressurized water reactor (PWR) (Figure 2-5) and boiling water reactor fuel (Figure 2-6), contained in seven full or nearly full assemblies, plus a few fuel pins in the 300 Area. This commercial fuel has enrichments of roughly 3 percent, exposures from 27.5 to $42 \mathrm{Mwd} / \mathrm{kg}$ uranium, and has aged from 10.5 to 12 years since irradiation.

The remainder of the fuel varies from small intact research reactor fuel assemblies and FFTF fuel pins to a large number of small pieces of destructively examined fuel from numerous DOE-sponsored programs. Fuel sources include the FFTF, the experimental breeder reactors at Idaho, commercial test reactors, and commercial power reactors. Approximately 0.3 metric tons of RINM is retrievably stored in shielded containers at the 200 West Area low-level burial grounds. More information on the physical, chemical, and radiological features and storage locations of this fuel is discussed in WHC-SD-SNF-TI-001, Rev. 0 (WHC 1994c). 
WHC-SD-SNF-TI-002, Rev. 0

Figure 2-4. FFTF Fuel Assembly.

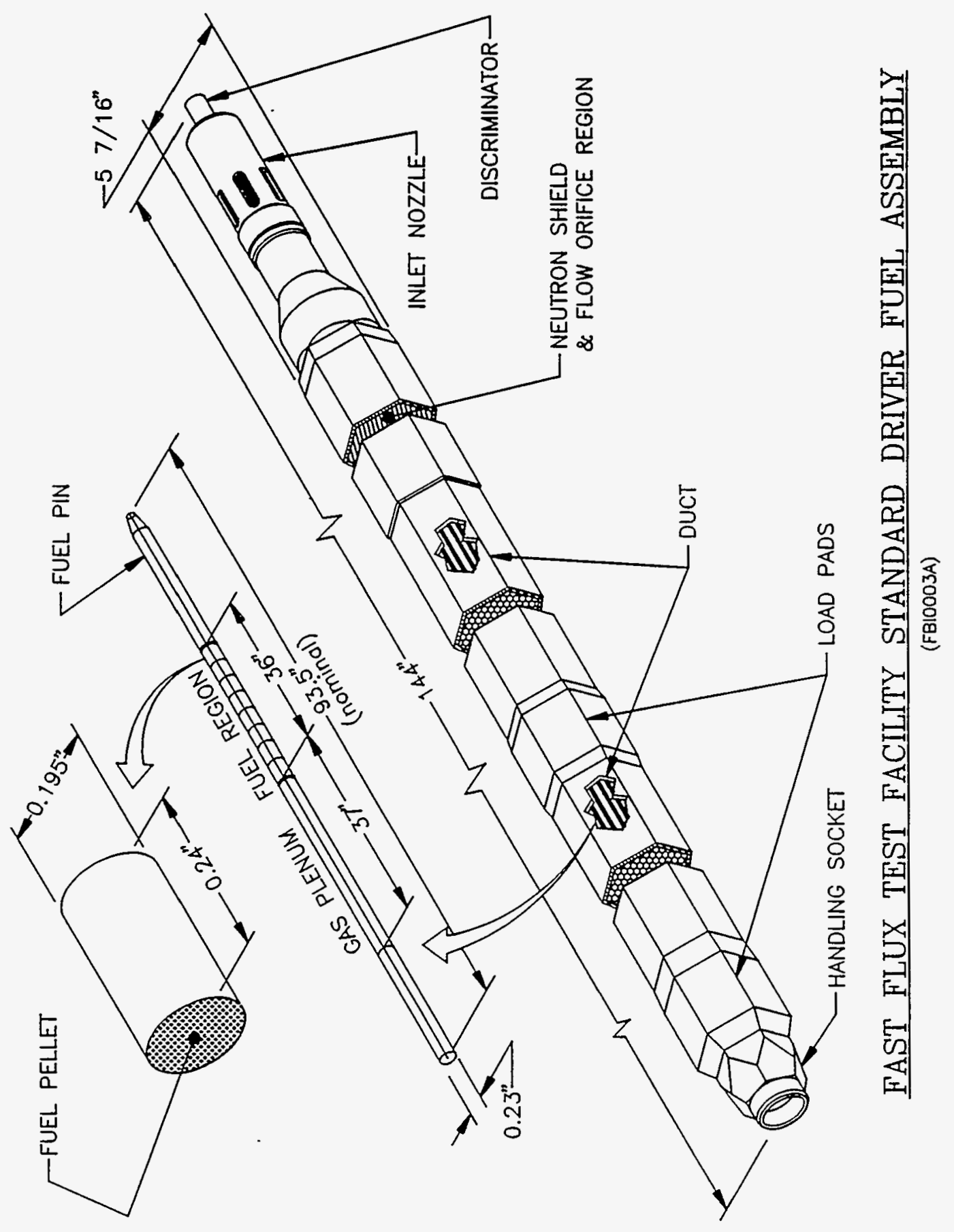




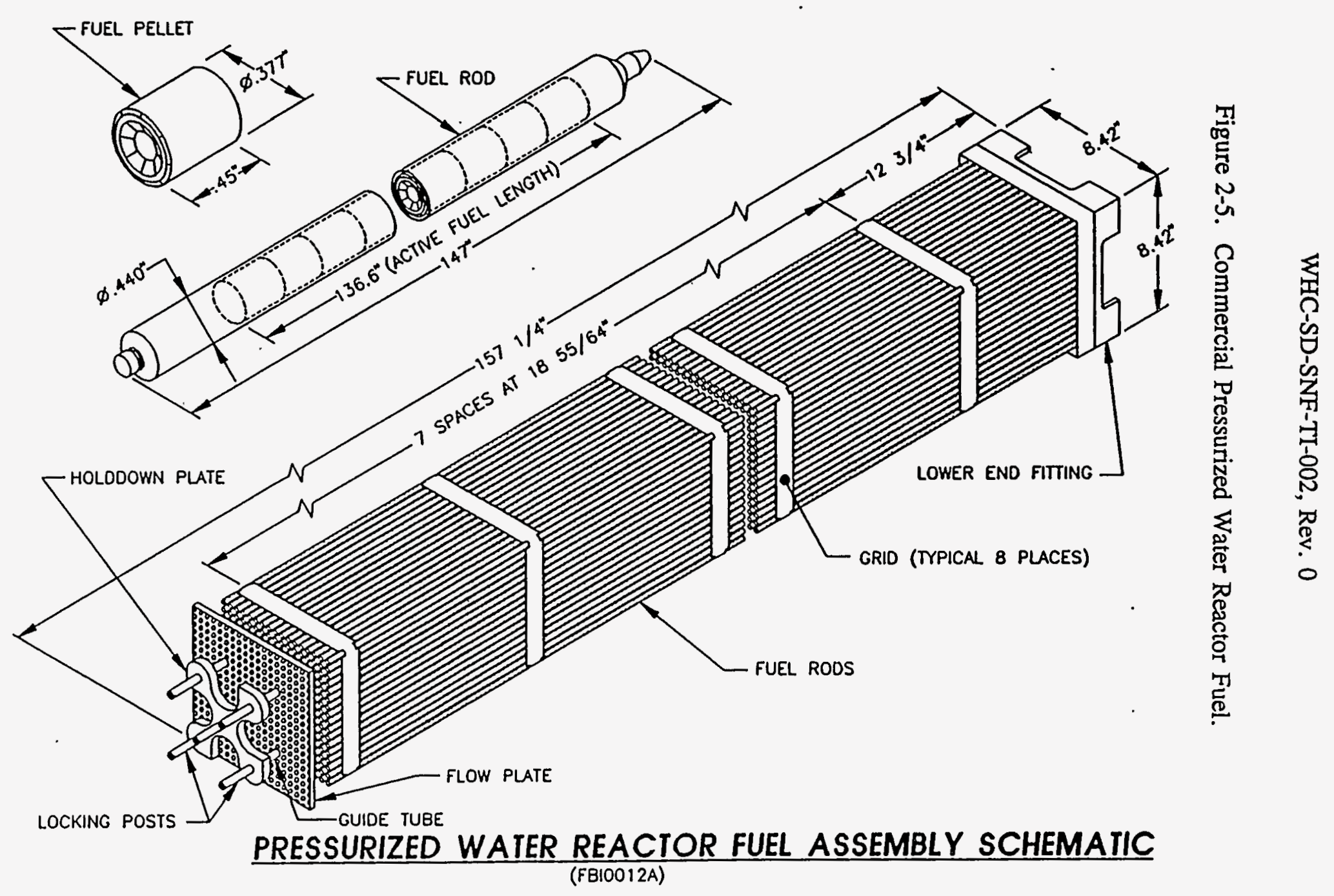


WHC-SD-SNF-TI-002, Rev. 0

Figure 2-6. Commercial Boiling Water Reactor Fuel.

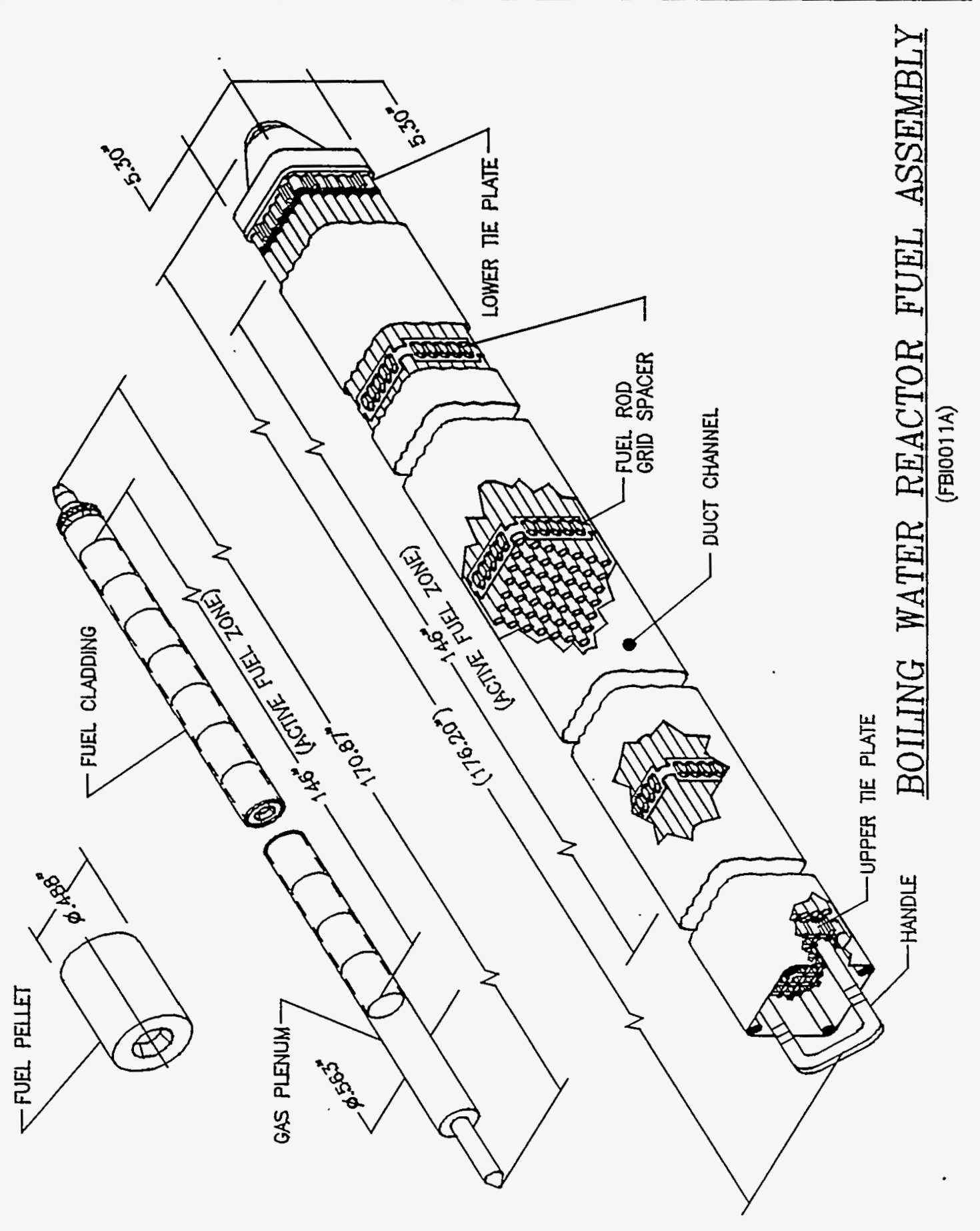




\subsection{5-KE AND 105-KW FUEL STORAGE BASINS}

\subsection{GENERAL INFORMATION}

The KE and KW Reactors are located in the 100 Area of the Hanford Site, $0.4 \mathrm{~km}$ (0.25 $\mathrm{mi}$ ) from the Columbia River. The two reactors were built in the early 1950's. The reactors were graphite-moderated plutonium-production reactors using once-through (singlepass) cooling. Each reactor was provided with a large basin for underwater storage of its irradiated fuel. The KW Reactor was shut down in February 1970, and the KE Reactor was shut down in February 1971. Essentially all stored fuel was shipped to the 200 East Area for processing, leaving the $105-\mathrm{KE}$ and $105-\mathrm{KW}$ fuel storage basins idle but filled with water. The facilities are shown schematically in Figures 3-1 through 3-4. The fuel storage in each basin is shown in Figure 3-5.

In the mid 1970's, a need for additional storage space for irradiated $\mathrm{N}$ Reactor fuel was identified. Projects H-501 (Gydesen 1977) and H-508 (Gydesen 1975) modified the 105-KE and 105-KW fuel storage basins, respectively, so the basins could be used for storage and handling of irradiated $\mathrm{N}$ Reactor fuel. Each modification project included a recirculating system for the fuel storage basin water, with in-line filters, an ion exchange system, a sand filter system, mechanical chillers, and instrumentation to monitor radiation levels, heat generation rate, and water level. In addition, the 105-KW fuel storage basin was drained, the walls were sandblasted, and an epoxy sealant was applied. Fuel storage racks were interlocked and positioned on each basin floor. The 105-KE fuel storage basin began storing irradiated $\mathrm{N}$ Reactor fuel in June 1975 . The $105-\mathrm{KW}$ fuel storage basin began storing irradiated $\mathrm{N}$ Reactor fuel in February 1981. After the irradiated fuel was placed in the $105-\mathrm{KE}$ and $105-\mathrm{KW}$ fuel storage basins, the primary mission of the $105-\mathrm{KE}$ and $105-\mathrm{KW}$ fuel storage basins has been the safe temporary storage of irradiated fuel. No missions other than irradiated fuel storage have been identified for the $105-\mathrm{KE}$ and $105-\mathrm{KW}$ fuel storage basins.

The modified 105-KE and 105-KW fuel storage basins were only intended to provide temporary storage of irradiated $\mathrm{N}$ Reactor fuel until it was processed at the PUREX Plant. The original intent was that no fuel would be stored in either the $105-\mathrm{KE}$ or $105-\mathrm{KW}$ fuel storage basin for longer than three years.

\subsection{FACILITY TECHNICAL AND OPERATIONS DESCRIPTION}

The 105- $\mathrm{KE}$ and 105- $\mathrm{KW}$ fuel storage basins are constructed of reinforced concrete walls and floors. The dimensions of each basin are $38 \mathrm{~m}(125 \mathrm{ft})$ long, $20 \mathrm{~m}(67 \mathrm{ft})$ wide, and $6 \mathrm{~m}(21 \mathrm{ft})$ deep. Each of the basins is divided into 3 bays by concrete partitions. 


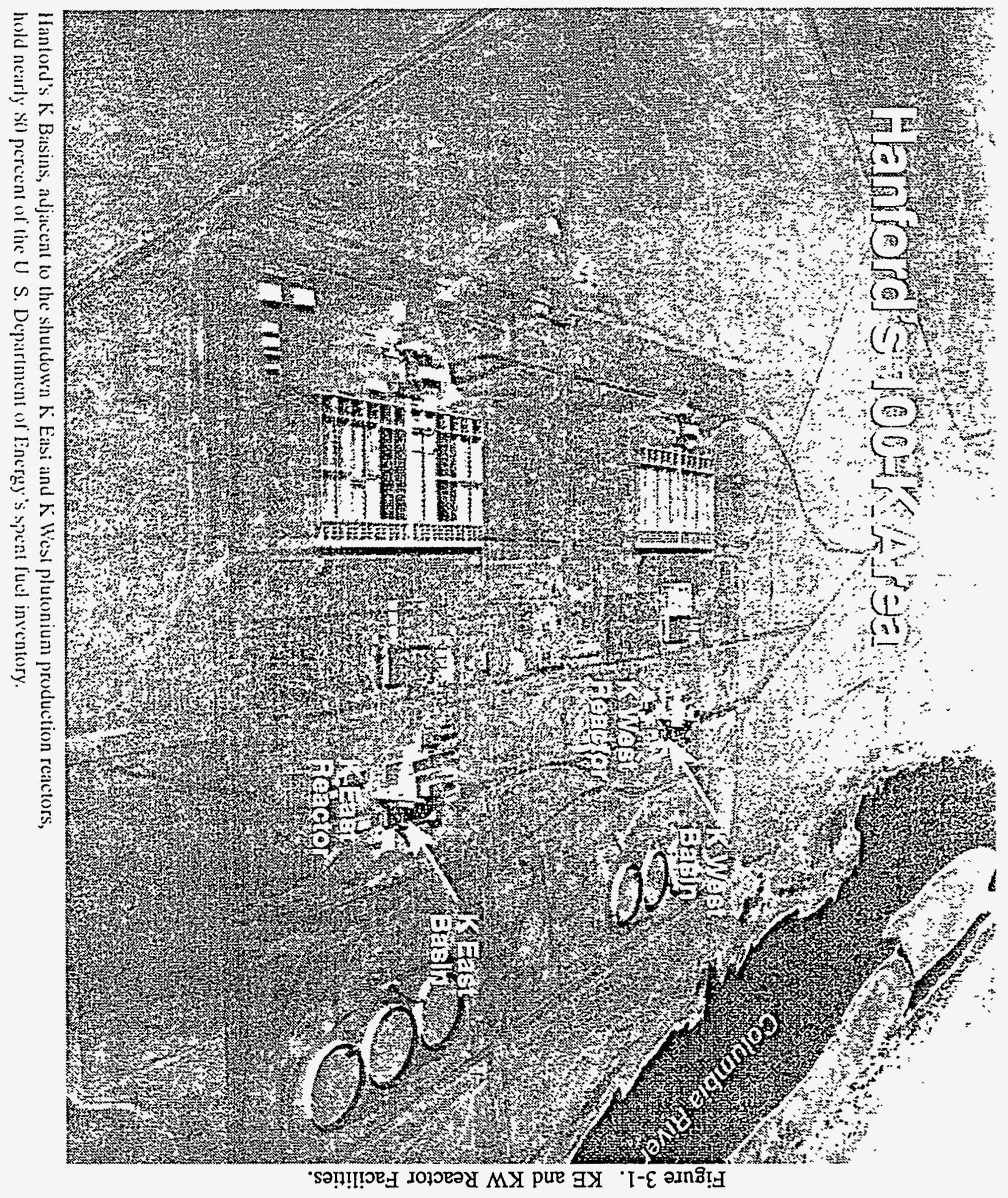




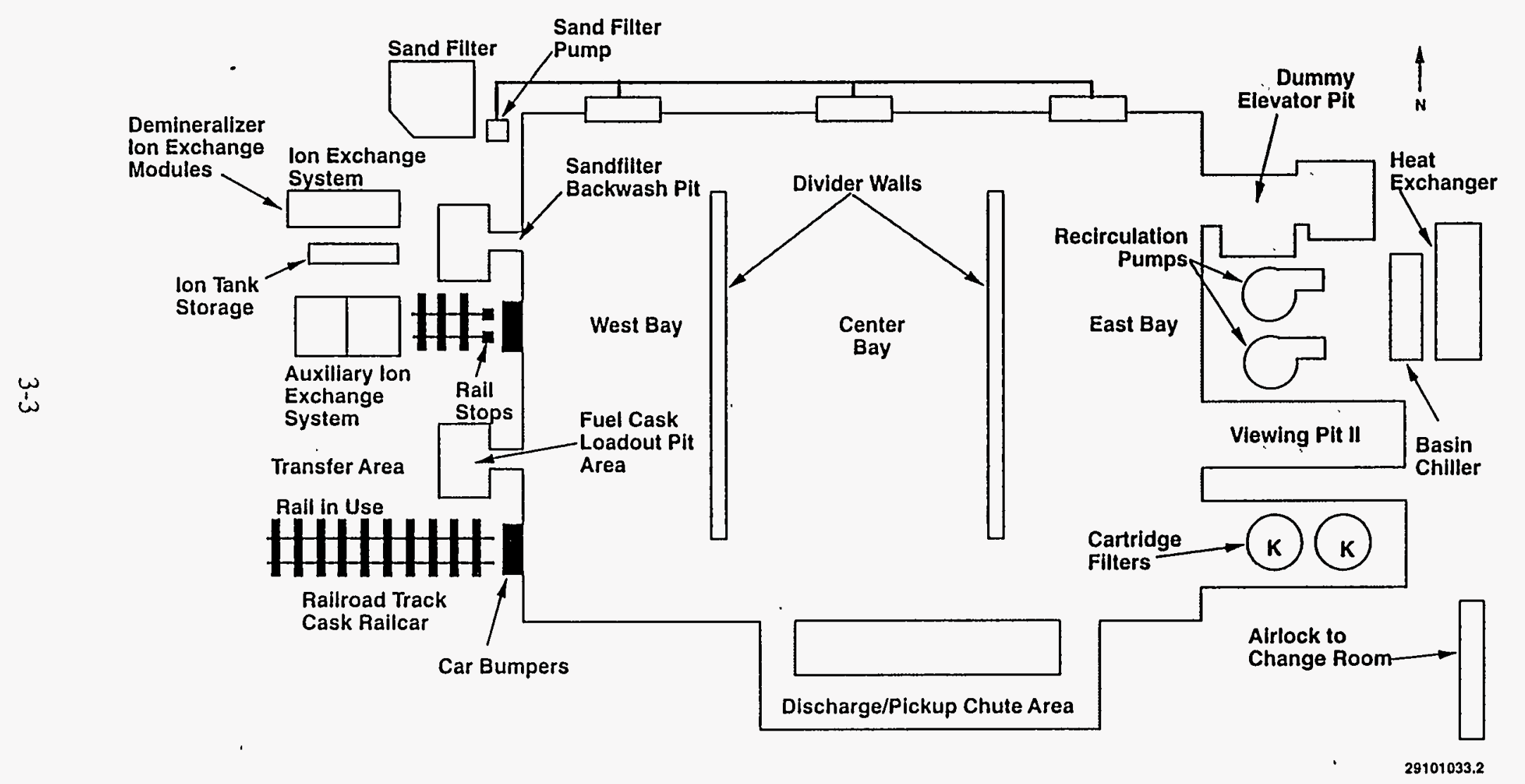

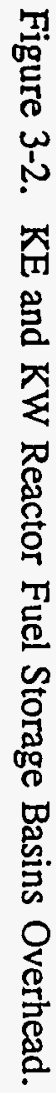




\section{WHC-SD-SNF-TI-002, Rev. 0}

Figure 3-3. KE and KW Reactor Fuel Storage Basins Cross-Section.

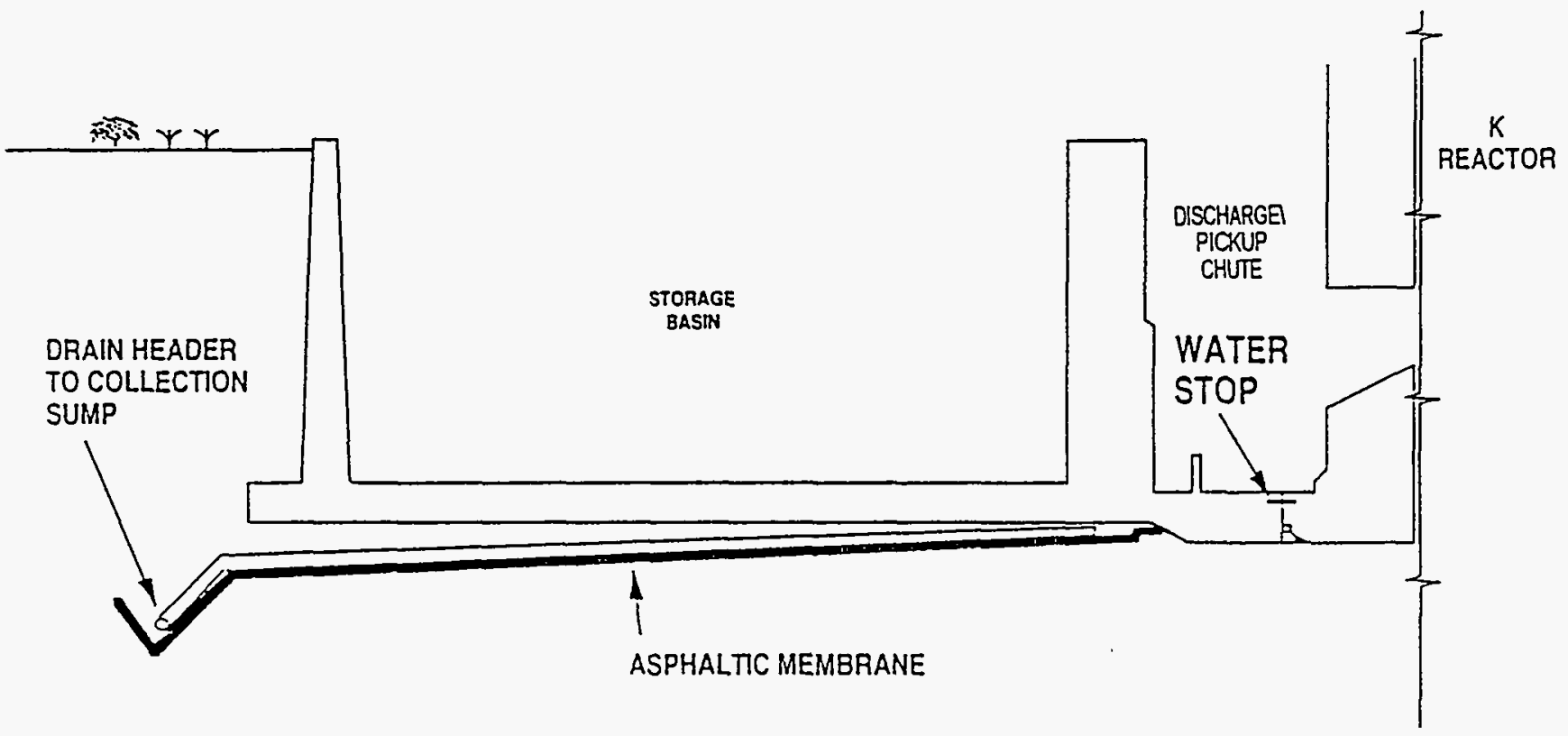


Figure 3-4. Floor Grating at the 105-KE and 105-KW Fuel Storage Basins.

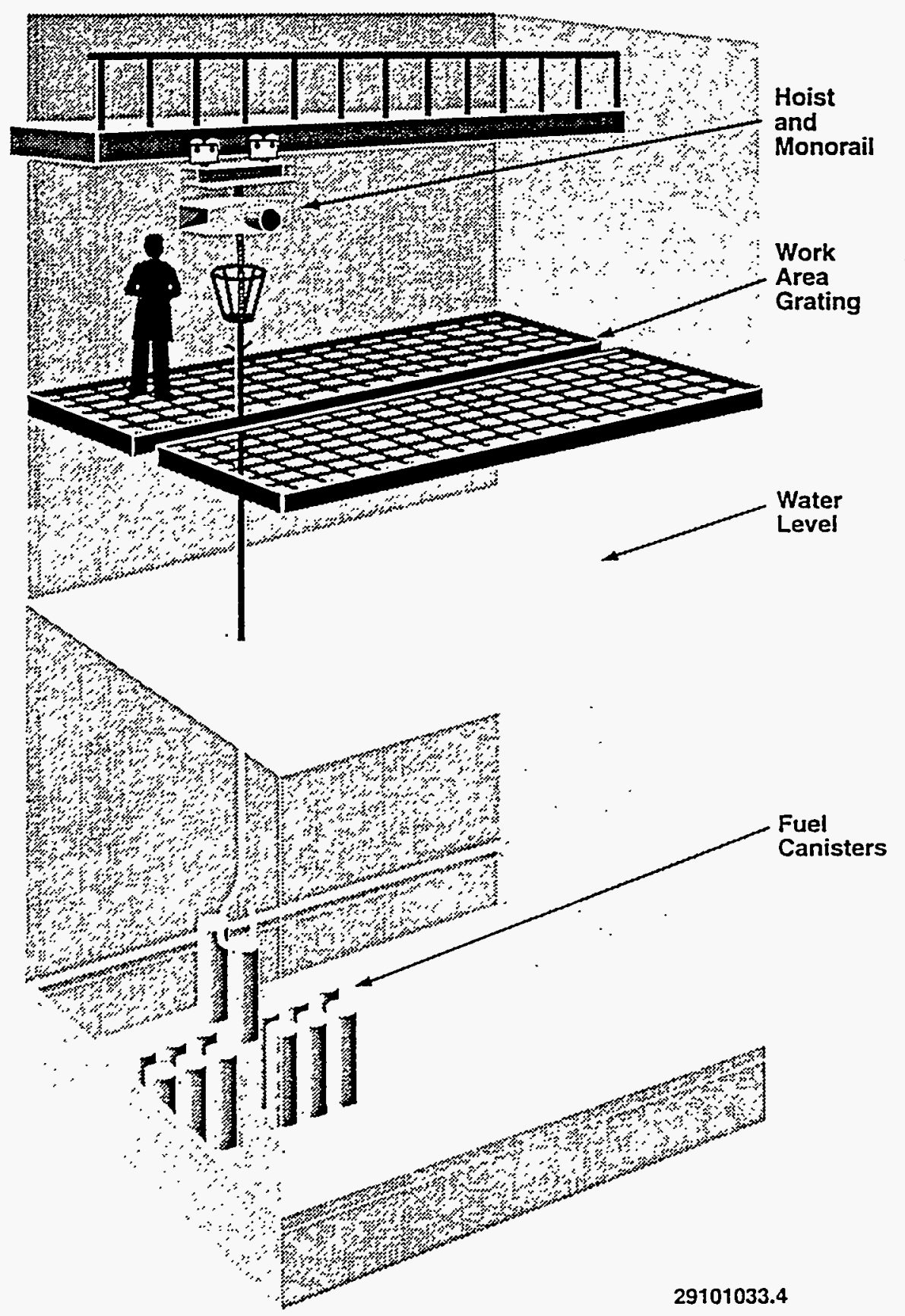


WHC-SD-SNF-TI-002, Rev. 0

Figure 3-5. Fuel Storage in the 105-KE and 105-KW Fuel Storage Basins.

(top view is $105-\mathrm{KE}$, bottom view is $105-\mathrm{KW}$ )

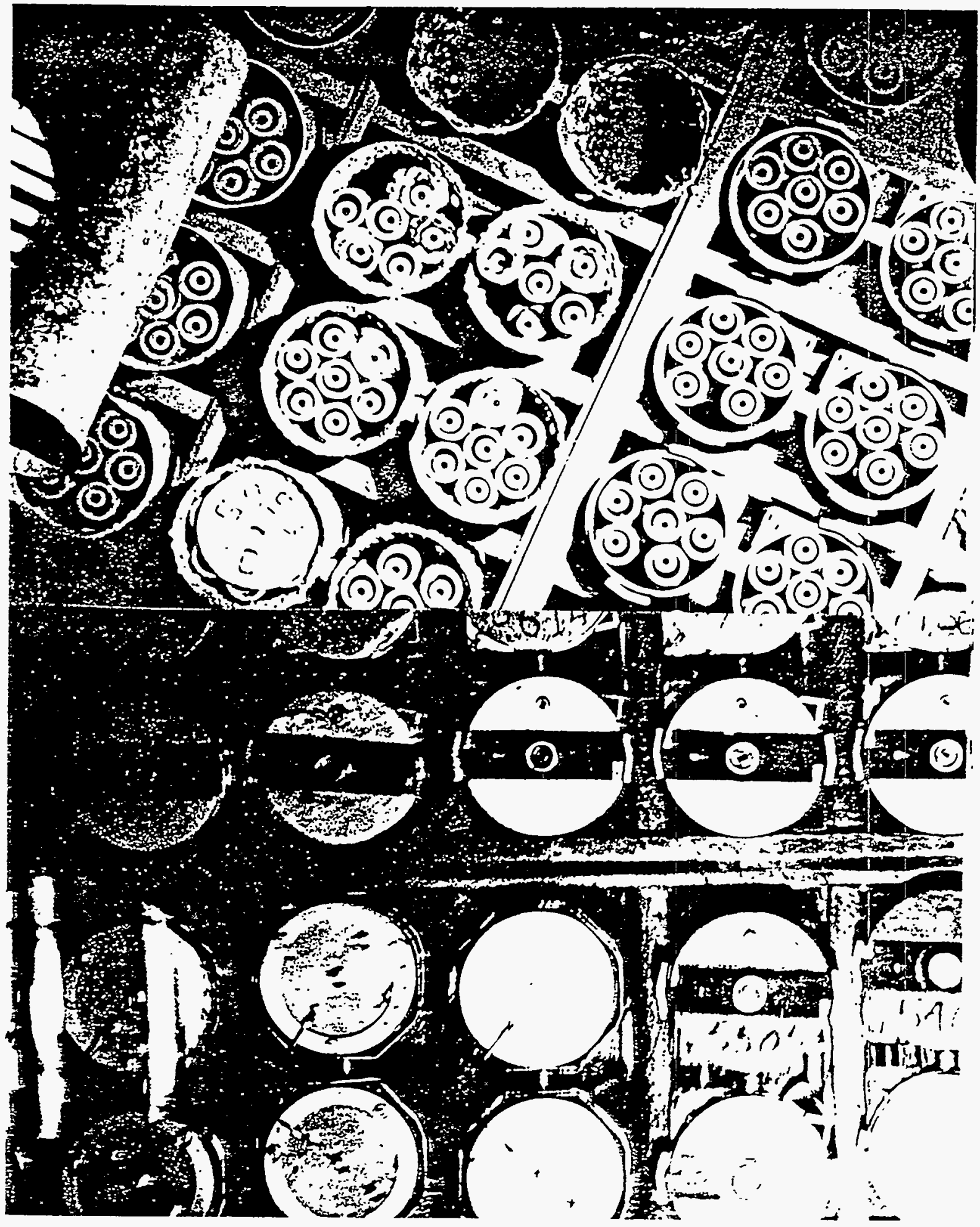


The partitions are open at each end allowing free movement of water between the bays. The discharge pickup chute (see Figures 3-2 and 3-3) originally served as a fuel element discharge and packaging area for the $\mathrm{KE}$ and $\mathrm{KW}$ Reactors during operation. The 105-KE fuel storage basin walls are a constant thickness of $69 \mathrm{~cm}(27 \mathrm{in}$.). The $105-\mathrm{KW}$ fuel storage basin walls are tapered from $69 \mathrm{~cm}$ at the base to $46 \mathrm{~cm}$ at the top (27 to $18 \mathrm{in}$.) with the exception of the west wall which is a constant thickness of $69 \mathrm{~cm}(27 \mathrm{in}$.). The 105-KE fuel storage basin has neither sealant nor liner on its concrete. The $105-\mathrm{KW}$ fuel storage basin has an epoxy sealant, but no liner.

Each basin is enclosed by a one-story steel-framed building. The building also houses the water treatment and cooling systems. The roof structure of the steel-framed building includes a monorail fuel transport system. A personnel floor grating system, covering the entire basin, is suspended from the roof structural steel framing (Figure 3-4).

In accordance with process standards, water levels are maintained in the 105-KE and $105-\mathrm{KW}$ fuel storage basins at a minimum of $4.72 \mathrm{~m}(15.5 \mathrm{ft})$ above the basin floor to cool the irradiated fuel and provide radiological shielding for personnel working in the facility. The water in each basin is cooled using the closed-loop mechanical chiller system. The filters and ion exchange systems maintain basin water clarity and remove radionuclides. Basin water temperature is maintained around $10 \circ \mathrm{C}(50 \circ \mathrm{F})$; basin water $\mathrm{Ph}$ is maintained between 5.5 and 8 , although it is normally between 6 and 7; basin water has an average conductivity of $10 \mu$ mhos with a range of 5 to $60 \mu$ mhos (WHC 1993f). Basin water temperature, $\mathrm{Ph}$, conductivity, and water level are continuously monitored. Used filters and spent ion-exchange system modules are TRU waste; other ion exchange components are generally low-level waste. Solid waste generated at the 105-KE and 105-KW fuel storage basins is disposed of in accordance with solid waste disposal requirements.

\subsection{IRRADIATED FUEL STORAGE AT THE 105-KE AND 105-KW FUEL STORAGE BASINS}

The fuel at the 105-KE and 105-KW fuel storage basins is stored in canisters on the bottom of the basins in single stacked storage racks. Three different types of fuel canisters (i.e., Mark 0, Mark I, and Mark II) hold the irradiated fuel elements (Figure 3-6). Each canister has two cylindrical barrels that hold up to seven elements vertically. Mark 0 canisters have perforated bottoms and open tops, and are made of aluminum. Mark I and Mark II canisters have solid bottoms and sealable tops; however, Mark I and Mark II canisters located in the $105-\mathrm{KE}$ fuel storage basin do not have the tops installed. Mark I canisters are made of either aluminum or stainless steel. All Mark II canisters are made of stainless steel. All three types of canisters are approximately $74 \mathrm{~cm}(28$ in.) high, have two cylindrical barrels approximately $22 \mathrm{~cm}(8.8 \mathrm{in}$.) diameter, and together extend approximately $47 \mathrm{~cm}$ (18 in.) including the joining trunnion. 


\section{WHC-SD-SNF-TI-002, Rev. 2}

Figure 3-6. N Reactor Fuel Storage Canisters.
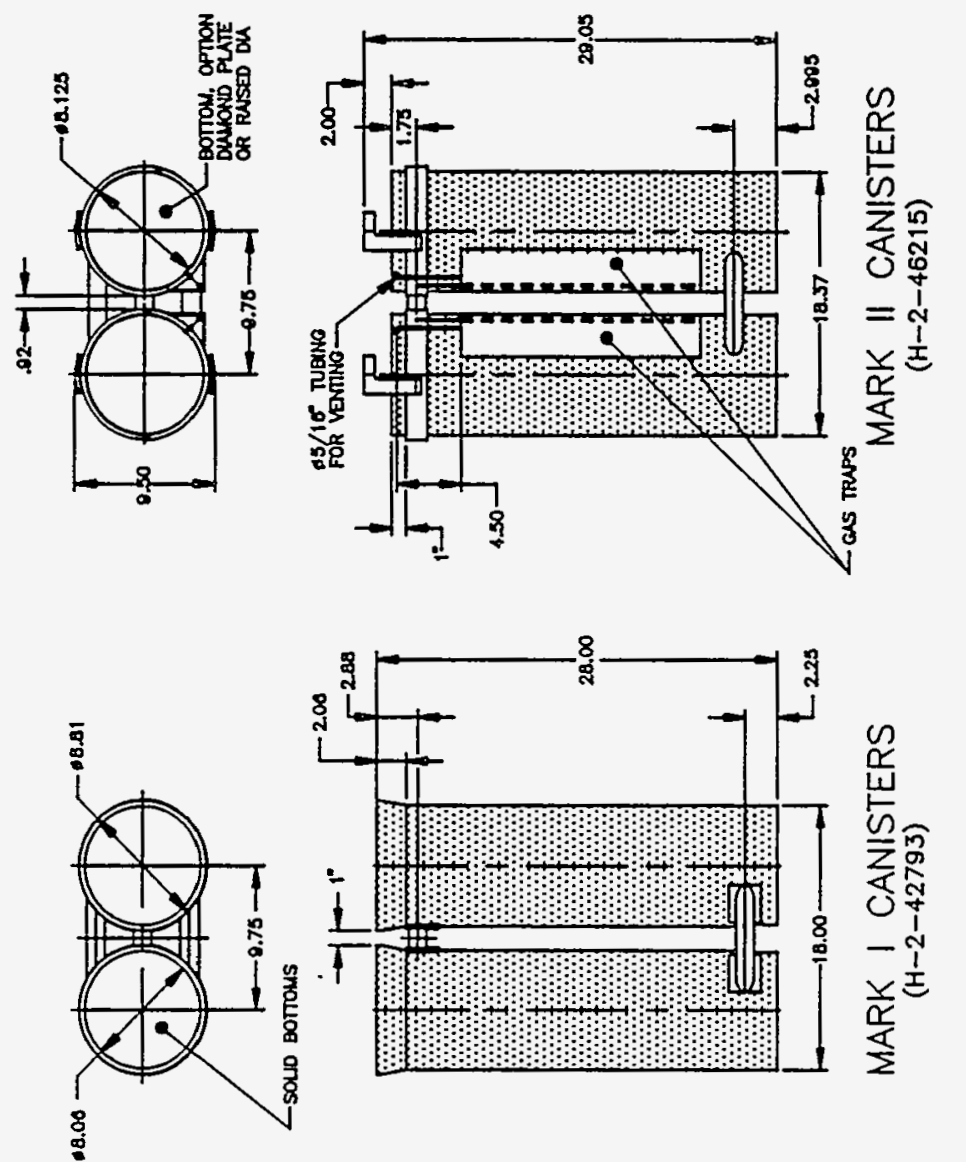

告

뎐
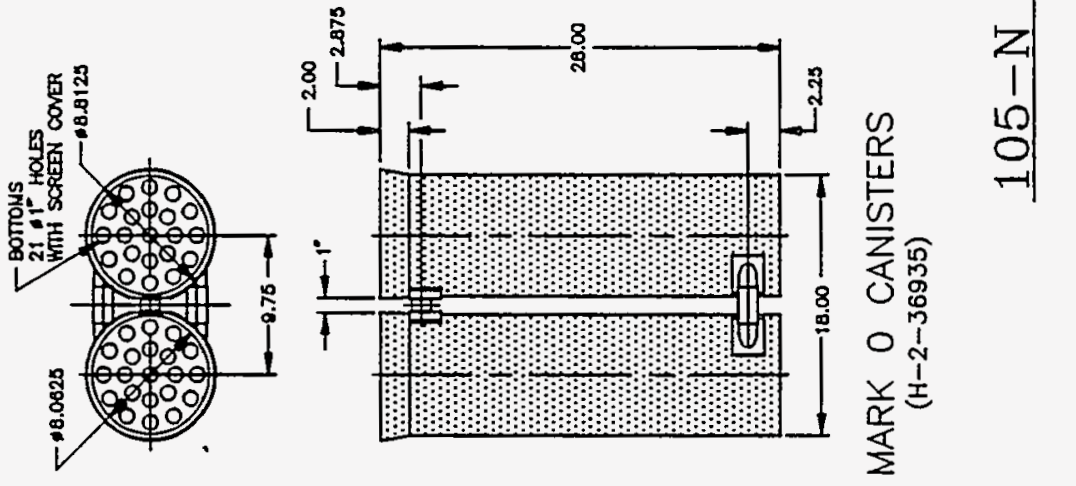
The irradiated fuel now stored in the 105-KE and 105-KW fuel storage basins has been in water-filled basin storage since discharged from reactors occurring from 1971 to 1987. In addition to $N$ Reactor fuel, a small amount of SPR fuel is also stored at the 105-KE fuel storage basin in small rectangular buckets. The materials of construction of the preirradiated fuel and radioisotopic composition of most of the irradiated fuel are listed in WHC-SD-SNF-TI-001, Rev. 0 (WHC 1994c). The 105-KE fuel storage basin contains 3,666 canisters containing 50,683 fuel elements. The $105-\mathrm{KW}$ fuel storage basin contains 3,815 canisters containing 52,959 fuel elements. The total mass of fuel elements at the $105-\mathrm{KE}$ fuel storage basin is 1,233 metric tons, the total mass of fuel elements in the $105-\mathrm{KW}$ fuel storage basin is 1,038 metric tons. Of this total mass, there is $1,143,600 \mathrm{~kg}$ uranium and $2,155 \mathrm{~kg}$ plutonium in the $105-\mathrm{KE}$ fuel storage basin and $951,900 \mathrm{~kg}$ uranium and $1,875 \mathrm{~kg}$ plutonium in the $105-\mathrm{KW}$ fuel storage basin.

The cladding on a significant fraction of the fuel was damaged at reactor discharge or during subsequent fuel handling. The exact number of damaged fuel elements is not known; however, it is estimated that from 6 to over 12 percent of the elements are damaged (WHC 1994c). As a result of the cladding damage, the uranium in some elements was exposed to the water and has oxidized during storage. The uranium oxidation causes the fuel elements to swell and leads to further damage of the cladding, thus exposing fresh uranium to the basin water and oxidation. The loss of cladding integrity and oxidation of the uranium allows soluble and gaseous fission products to dissolve into the canister water. The open canisters used in the 105-KE fuel storage basin allow free exchange of water between the canister and the basin; therefore, soluble and gaseous fission products are continually released to the water of the 105-KE fuel storage basin.

All of the canisters in the $105-\mathrm{KW}$ fuel storage basin have closed lids and bottoms; therefore, with the exception of gaseous products, contamination resulting from damaged and/or oxidized fuel has been contained within the canisters. As compared to the 105-KE fuel storage basin, the water in the $105-\mathrm{KW}$ fuel storage basin is relatively free of contamination.

In 1983 and 1984, Mark IV fuel in the 105-KE fuel storage basin was segregated into fuels and weapons grade inventories. The segregation process involved removing the fuel from the canister, separating the inner element from the outer, measuring the ${ }^{240} \mathrm{Pu}$ content of the elements, reassembling similar grade elements, repackaging the fuel into canisters, and replacing the canisters in the basin.

In the 105-KE fuel storage basin, a significant amount of sludge has accumulated on the floor. The composition of the sludge has not been completely characterized; however, it is postulated that the sludge consists of uranium oxide from the damaged fuel, iron oxide from the fuel storage racks, concrete grit from the concrete walls, and other materials including mixed insoluble fission products, ceiling materials, and small fuel pieces (DOE-RL 1993a). The pieces of fuel contained in the sludge originates either from fuel that was stored in the older storage canisters (i.e., pieces fell through the screen bottoms of the 
WHC-SD-SNF-TI-002, Rev. 0

canisters) or from fuel that was handled during fuel segregation and/or processing at PUREX.

\subsection{FUEL TRANSPORTATION}

The fuel was transported to and from the 105-KE and 105-KW fuel storage basins by rail. Specially designed irradiated fuel casks and railroad well cars were used for onsite movement of both SPR and N Reactor fuels. A detailed description of the cask and railroad well cars used is available in WHC-SD-SNF-TI-001, Rev. 0 (WHC 1994c). Cask-handling capability is similar at both basins and is fairly restrictive. Crane capacity is 27 metric tons $(60,000 \mathrm{lb})$. Casks must be loaded under water and must be less than $2.6 \mathrm{~m}(8.5 \mathrm{ft})$ tall. The cask transfer pit is $2.1 \mathrm{~m}(6.9 \mathrm{ft}) \times 2.8 \mathrm{~m}(9.2 \mathrm{ft})$, but framework within the loading pit reduces the free clearance to $1.5 \mathrm{~m}(4.9 \mathrm{ft}) \times 1.2 \mathrm{~m}(3.9 \mathrm{ft})$. Also, only the transfer pit located on the south side of the basin is functional.

Each well car was capable of containing three casks, and each cask of containing three canisters. Using hoists and separately attached lifting rods, the canisters were removed from the casks and then moved along an underwater path, using an interconnecting network of slots built into the floor-grating covers, to the predetermined storage space within the storage rack. The canisters can be shifted to and from the storage basins into the abutting pits or pickup station for subsequent unloading, loading, reviewing, or inspection operations as needed.

A high level of effort would be required to return the existing casks and rail cars to use. The casks and the railroad well cars were never certified for shipment of irradiated fuel offsite. Even for shipment onsite, there would be increased regulatory requirements. These packagings have not been used since 1989, and both the casks and well cars are contaminated and rusty. At a minimum, a significant effort to produce new or revised safety and engineering documentation would be required to support use of the railcars. Additionally, cleaning and decontamination of the equipment would also be required to support the transport of any irradiated fuel from the 105-KE and 105-KW fuel storage basins to another location on the Hanford Site (WHC 1993a).

\subsection{CONTINUED STORAGE AT THE 105-KE AND 105-KW FUEL STORAGE BASINS}

The 105-KE and the 105-KW fuel storage basins each currently have about 25 percent unused capacity (assuming no stacking)7. An engineering study is evaluating the consolidation of irradiated $\mathrm{N}$ Reactor fuel and sludge in triple-tiered storage racks at the 105$\mathrm{KW}$ fuel storage basin. Fuel enrichment is limited to 0.947 percent in the $105-\mathrm{KE}$ fuel storage basin by criticality consideration because of the sludge accumulation on the basin floor. 
The mission of the 105-KE fuel storage basin is under close scrutiny by the Washington State Department of Ecology, the U.S. Environmental Protection Agency, and DOE because of concerns with leakage of contaminated water to the environment and the relative proximity to the Columbia River. The Hanford Federal Facility Agreement and Consent Order (Ecology et al. 1994), also known as the Tri-Party Agreement, lists actions to be taken, with completion dates, for the $105-\mathrm{KE}$ and $105-\mathrm{KW}$ fuel storage basins. The major actions are (1) the encapsulation of the fuel and sludge at the 105-KE fuel storage basin, .(2) disposal of the water in the 105-KE fuel storage basin, (3) initiation of the Hanford Sitespecific fuels EIS, and (4) removal of the fuel from the $105-\mathrm{KE}$ and $105-\mathrm{KW}$ fuel storage basins.

A number of upgrades are planned to "improve the storage" at the $105-\mathrm{KE}$ and $105-\mathrm{KW}$ fuel storage basins. In addition to the 105- KE fuel encapsulation (recanning) and sludge packaging, the following activities may allow up to 20 years of additional storage in the 105-KE and 105-KW fuel storage basins:

- A new water treatment system for basin makeup water (Project N-027) will service both the 105-KE and $105-\mathrm{KW}$ fuel storage basins. The existing system was designed to support reactor operation and is grossly oversized for current facility needs. The new system will provide reliable and appropriately sized potable water, distribution piping, and a dedicated fire protection system in the $100 \mathrm{~K}$ Area.

- $\quad$ Reroofing is planned for the $105-\mathrm{KE}$ fuel storage basin, fuel transfer, and office areas. Roof repair is planned for the $105-\mathrm{KW}$ fuel transfer and office areas.

In addition to the upgrades listed above, the following are issues of concern that have also been raised and need to be addressed in order to allow continued storage in the basins:

- An occurrence report, UO RL-WHC-KBASINS-1994-0007, Post Seismic Leakage (WHC 1994e) identified recent analyses indicating that post-seismic leakage from the unsupported water-wetted $105-\mathrm{KE}$ and $105-\mathrm{KW}$ fuel storage basin construction joint has the potential to exceed the $95 \mathrm{~L} / \mathrm{min}$ ( $25 \mathrm{gal} / \mathrm{min}$, 1,500 gal/hour) leakage as defined in the safety analysis report (SAR) (WHC 1993d). The occurrence report concluded that a DISCOVERY (i.e., potential unreviewed safety question) exists. The unreviewed safety question process will identify near- and long-term resolution for the unreviewed safety question.

- Continued degradation of the damaged fuel and the radionuclide releases to the $105-\mathrm{KE}$ fuel storage basin cooling water has produced higher dose rates to workers than those found in the 105-KW fuel storage basin, which stores fuel in sealed canisters. There is also a "bathtub" ring in the 105-KE fuel storage 
basin resulting from fuel failures that release fission products to the basin which further increases worker dose rates.

- Hydrogen and gaseous fission products (resulting from the water oxidation of uranium metal fuel and radiolytic degradation of water) are released to the fuel storage basins and the air above the basins. Hydrogen may tend to accumulate in the sealed canisters in the $105-\mathrm{KW}$ fuel storage basin.

- Tritiated water disposition/disposal is a concern in the 105-KE and 105-KW fuel storage basins.

Safety concerns related to continued storage of fuel at the Hanford Site 105-K fuel storage basins have led to proposed accelerated actions to remove the fuel from the basins in lieu of continued storage for an indefinite period. These safety concerns are reflected in the Defense Nuclear Facilities Safety Board Recommendation 94-1 (Conway 1994) and in the "DOE Spent Fuel Working Group Report on Inventory and Storage of the Department's Spent Nuclear Fuel and other Reactor Irradiated Nuclear Materials and the Environmental, Safety, and Health Vulnerabilities" (DOE 1993). A path forward to remove fuel from the 105-K fuel storage basins was selected in November 1994.

The path forward calls for the SNF to be placed in overpacks on an accelerated basis. The SNF would be transported to a new storage facility, where the fuel would be temporarily wet stored in the overpacks. The SNF would then be moved to a new facility, where it would be dewatered, dried, dehydrided, and passivated, and then returned to the same new storage facility for dry storage pending its ultimate disposition. The information prescribed in this document was developed prior to selection of the path forward for fuel removal from the basins. Accordingly, future revision of the document will incorporate changes resulting from the path forward decision.

\subsection{ESTIMATED STAFF SIZE AND OPERATIONAL COST}

\subsubsection{Staff Size}

The following Operations staff of 176 personnel are required at the $105-\mathrm{KE}$ and 105-KW fuel storage basins:

- Approximately 25 operators perform required maintenance and surveillance activities at the basins. These personnel routinely work in radiation zone areas of the facility. This is the minimum number required to meet radiation protection requirements in WHC-CM-1-6, WHC Radiological Control Manual (see estimated operational dose commitment section). Activities, such as sludge encapsulation, will require additional operators because of additional work scope and increased dose commitment (WHC 1991a). 
- Exempt staff account for approximately 132 employees, including managers and supervisors, an engineering staff, a work control staff, accountability staff, quality assurance/quality control personnel, and administrative staff). In general, these personnel enter radiation zone areas only occasionally; however, some personnel (notably the accountability personnel) require a larger-thantypical staff size to meet radiation protection requirements.

- Nonexempt staff account for approximately 19 employees, including secretaries, clerks, and technicians.

- The maintenance staff accounts for 68 employees $^{1}$, including 12 managers or exempt personnel, 4 nonexempt clerical personnel, and 52 crafts personnel. The managers, exempt personnel, and clerical staff only enter radiation zones occasionally if at all. The crafts personnel perform routine maintenance and minor upgrades to facility systems, and routinely work in radiation zone areas. Instrument technicians, pipefitters, millwrights, iron workers, electricians, painters, and other crafts personnel are located at the basins. Additional personnel are often required for nonroutine projects such as sludge encapsulation.

- The Health Physics staff accounts for 35 employees $^{2}$, including 6 managers or exempt personnel, 1 secretary, and 28 health physics technicians. The . managers, exempt personnel, and secretary only enter radiation zones occasionally if at all. The technicians routinely work in radiation zone areas. Twenty-eight is the minimum number required to meet radiation protection requirements.

The total number of personnel at the $105-\mathrm{KE}$ and $105-\mathrm{KW}$ fuel storage basins is approximately 280 . Of these personnel, 115 work routinely in radiation zone areas. The number of personnel and the operational costs are based on actual 1993 figures. The number of maintenance personnel required may decline somewhat following planned major upgrades to the electrical and water systems. The total number of personnel required following upgrade activities is not available.

\subsubsection{Operational Cost}

There are two types of operational costs, routine annual costs and nonroutine or project costs. The routine annual operational cost of the $105-\mathrm{KE}$ and $105-\mathrm{KW}$ fuel storage basins is budgeted at approximately $\$ 40$ million $^{3}$. Of that amount, approximately

\footnotetext{
'Information provided by $\mathrm{K}$ Basins Maintenance.

${ }^{2}$ Information provided by $\mathrm{K}$ Basins Radiation Protection Technology.

${ }^{3}$ Information provided by $\mathrm{K}$ Basins Support.
} 
$\$ 20$ million (50 percent) is required for operations and maintenance, salaries, utilities, administrative and maintenance supplies, and other costs. Roughly 15 percent of the total budget goes to engineering support. Engineering support funds are primarily used for salaries of dedicated or supporting engineering groups. The final 35 percent of the total budget is split between numerous diverse support organizations such as Environmental Compliance and Safeguards and Security.

In addition to the $\$ 40$ million annual routine operation cost, the total costs for fiscal year 1995 planned upgrades are estimated. The costs listed below reflect one-time expenditures. All of the activities are required for continued storage of $\mathrm{N}$ Reactor fuel in the $105-\mathrm{KE}$ and $105-\mathrm{KW}$ fuel storage basins.

- $100 \mathrm{~K}$ Area water supply and distribution upgrade

- Fire protection upgrades

- Electrical system upgrades

- Maintenance shop upgrades
$\$ 6$ million

$\$ 2$ million

$\$ 3$ million

$\$ 3$ million.

\subsection{ESTIMATED OPERATIONAL DOSE COMMITMENT}

The actual dose rate varies greatly from location to location in the 105-KE and $105-\mathrm{KW}$ fuel storage basins. The dose rates are substantially higher for the 105-KE fuel storage basin than for the 105-KW fuel storage basin. The dose rates in the 105-KE fuel storage basin are generally higher near the walls than in the center of the basin. The higher dose rate near the walls is attributed to transport and absorption of cesium in the bare concrete.

The following are the estimated routine operational dose commitments for the $105-\mathrm{KE}$ and 105-KW fuel storage basins (WHC 1991a):

- 105-KE Basin: 17 man-rem/year for maintenance and operations routines

- 105-KW Basin: 4 man-rem/year for maintenance and operations routines.

These estimates are based on the radiation fields in the basins and the amount of time required to perform routine surveillance and maintenance activities. This dose is spread between operators, crafts workers, health physics technicians, accountability personnel, and others. Without advance approval, no single individual is to receive a dose greater than $500 \mathrm{mrem} /$ year (WHC-CM-1-6, WHC Radiological Control Manual).

Nonroutine activities will result in a larger estimated dose than routinely obtained. 
WHC-SD-SNF-TI-002, Rev. 0

\subsection{ESTIMATED ROUTINE ENVIRONMENTAL RELEASES}

The estimated environmental releases have been divided into four categories as follows:

- Radiological airborne emissions

- Nonradiological airborne emissions

- Radiological liquid effluents

- Nonradiological liquid effluents.

\subsubsection{Radiological Airborne Emissions}

Radiological airborne emissions from the operation of the $105-\mathrm{KE}$ fuel storage basin are presented for calendar years 1990, 1991, and 1992 in Table 3-1. The release is from four vents that exhaust unfiltered air from the fuel storage basin in the 105-KE Building. Emission monitoring consists of four emission (record) samplers used to calculate the total release based on the respective flows in each of the four vents. The definition of record sampling and the method used can be found in WHC-CM-7-5, WHC Environmental Compliance Manual, Section 2. The 105-KE fuel storage basin is a registered exhaust emission point that has been designated as a minor stack at the Hanford Site with the potential to emit less than $0.1 \mathrm{mrem} / \mathrm{year}$ to the maximally exposed offsite individual.

Radiological airborne emissions from the operation of the $105-\mathrm{KW}$ fuel storage basin are presented for calendar years 1990, 1991, and 1992 in Table 3-2. The release points are four vents that exhaust unfiltered air from the fuel storage basin in the 105-KW Building. Emission monitoring consists of three emission (record) samplers used to calculate the total release based on the air flows from each vent. The definition of record sampling and the method used can be found in WHC-CM-7-5, Section 2. The 105-KW fuel storage basin is a registered exhaust emission point that has been determined to be a minor stack at the Hanford Site with the potential to emit less than $0.1 \mathrm{mrem} / \mathrm{year}$ to the maximally exposed offsite individual. 


\subsubsection{Non-Radiological Airborne Emissions}

There is no routine monitoring of nonradioactive releases for either the 105-KE or $105-\mathrm{KW}$ fuel storage basins. A review of the facilities determined that there was insignificant potential for chemicals to be released via any of the release points. As a result of the nature and small inventory of materials, any releases which might occur are considered to be insignificant, and therefore no constituents are measured.

\subsubsection{5-KE and 105-KW Fuel Storage Basins Stack Information (DOE-RL 1993b and WHC 1993b)}

The 105-KE fuel storage basin has 4 exhaust points. Two of them (i.e., low-bay roof ventilators $R V-10$ and $R V-11$ ) exhaust the fuel storage area, and the two other exhaust points (i.e., high-bay roof ventilators RV-6 and RV-7) exhaust the water treatment area. The fuel storage area and water treatment area share the same air space within the facility.

Table 3-1. 105-KE Fuel Storage Basin Radiological Airborne Emissions.

\begin{tabular}{|l|c|c|c|}
\hline \multicolumn{1}{|c|}{ Nuclide } & $\begin{array}{c}1992 \text { totals (Ci) } \\
\text { (DOE-RL 1993b) }\end{array}$ & $\begin{array}{c}1991 \text { totals (Ci) } \\
\text { (DOE-RL 1992) }\end{array}$ & $\begin{array}{c}1990 \text { totals (Ci) } \\
\text { (DOE-RL 1991) }\end{array}$ \\
\hline${ }^{60} \mathrm{Co}$ & $1.3 \mathrm{E}-06$ & $1.1 \mathrm{E}-05$ & $4.1 \mathrm{E}-05$ \\
\hline${ }^{90} \mathrm{Sr}$ & $1.6 \mathrm{E}-04$ & $7.5 \mathrm{E}-05$ & $3.6 \mathrm{E}-04$ \\
\hline${ }^{106} \mathrm{Ru}$ & $1.3 \mathrm{E}-05$ & $1.5 \mathrm{E}-04$ & Not detected \\
\hline${ }^{125} \mathrm{Sb}$ & $1.1 \mathrm{E}-05$ & $9.2 \mathrm{E}-06$ & Not detected \\
\hline${ }^{134} \mathrm{Cs}$ & Not detected & Not detected & $2.8 \mathrm{E}-05$ \\
\hline${ }^{137} \mathrm{Cs}$ & $2.3 \mathrm{E}-04$ & $5.7 \mathrm{E}-05$ & $6.8 \mathrm{E}-05$ \\
\hline${ }^{238} \mathrm{Pu}$ & $1.3 \mathrm{E}-06$ & $8.7 \mathrm{E}-07$ & 1.2 E-07 \\
\hline${ }^{239.240} \mathrm{Pu}$ & $8.5 \mathrm{E}-06$ & $5.4 \mathrm{E}-06$ & 9.0 E-07 \\
\hline${ }^{241} \mathrm{Pu}$ & $3.9 \mathrm{E}-05$ & Not analyzed & Not analyzed \\
\hline${ }^{241} \mathrm{Am}$ & $5.1 \mathrm{E}-06$ & Not analyzed & Not analyzed \\
\hline Total flow $\left(\mathrm{m}^{3}\right)$ & $7.5 \mathrm{E}+08$ & $4.0 \mathrm{E}+08$ & 4.1 E+08 \\
\hline
\end{tabular}


Table 3-2. 105-KW Fuel Storage Basin Radiological Airborne Emissions.

\begin{tabular}{|l|c|c|c|}
\hline \multicolumn{1}{|c|}{ Nuclide } & $\begin{array}{c}1992 \text { totals (Ci) } \\
\text { (DOE-RL 1993b) }\end{array}$ & $\begin{array}{c}1991 \text { totals (Ci) } \\
(\text { DOE-RL 1992) }\end{array}$ & $\begin{array}{c}1990 \text { totals (Ci) } \\
(\text { DOE-RL 1991) }\end{array}$ \\
\hline${ }^{54} \mathrm{Mn}$ & Not detected & Not detected & $2.4 \mathrm{E}-05$ \\
\hline${ }^{60} \mathrm{Co}$ & $1.4 \mathrm{E}-06$ & $7.4 \mathrm{E}-06$ & $3.4 \mathrm{E}-05$ \\
\hline${ }^{90} \mathrm{Sr}$ & $9.9 \mathrm{E}-07$ & $6.7 \mathrm{E}-07$ & $1.6 \mathrm{E}-06$ \\
\hline${ }^{106} \mathrm{Ru}$ & $6.2 \mathrm{E}-06$ & Not detected & Not detected \\
\hline${ }^{134} \mathrm{Cs}$ & Not detected & $7.4 \mathrm{E}-06$ & Not detected \\
\hline${ }^{137} \mathrm{Cs}$ & $2.7 \mathrm{E}-05$ & $1.2 \mathrm{E}-05$ & $2.9 \mathrm{E}-05$ \\
\hline${ }^{154} \mathrm{Eu}$ & $4.9 \mathrm{E}-06$ & Not detected & Not detected \\
\hline${ }^{238} \mathrm{Pu}$ & $3.0 \mathrm{E}-08$ & Not detected & $1.7 \mathrm{E}-09$ \\
\hline${ }^{239.240} \mathrm{Pu}$ & $1.8 \mathrm{E}-07$ & $7.9 \mathrm{E}-09$ & $1.2 \mathrm{E}-08$ \\
\hline Total flow $\left(\mathrm{m}^{3}\right)$ & $7.5 \mathrm{E}+08$ & $4.0 \mathrm{E}+08$ & $4.1 \mathrm{E}+08$ \\
\hline
\end{tabular}

All of these roof ventilators discharge their effluent horizontally. Each of the four exhaust points has four associated samplers (WHC 1994f).

Flow Rate: $1,551,400 \mathrm{~L} / \mathrm{min}\left(54,781 \mathrm{ft}^{3} / \mathrm{min}\right)$ total for all four exhaust points

$$
\begin{aligned}
& \text { RV-6 } 487,250 \mathrm{~L} / \min \left(17,205 \mathrm{ft}^{3} / \mathrm{min}\right) \\
& \text { RV-7 } 282,380 \mathrm{~L} / \min \left(9,971 \mathrm{ft}^{3} / \mathrm{min}\right) \\
& \text { RV-10 } 233,100 \mathrm{~L} / \min \left(8,231 \mathrm{ft}^{3} / \mathrm{min}\right) \\
& \text { RV-11 } 395,570 \mathrm{~L} / \min \left(13,968 \mathrm{ft}^{3} / \mathrm{min}\right)
\end{aligned}
$$

Exhaust point: RV-6 and RV-7 are $13 \mathrm{~m}$ (42 ft) above ground level, and

$\mathrm{RV}-10$ and RV-11 are approximately $4.6 \mathrm{~m}(15 \mathrm{ft})$ above ground level

Diameter: RV-6 $100 \mathrm{~cm}$ (40 in.) square

RV-7 $81 \mathrm{~cm}(34 \mathrm{in}$.) square

$\mathrm{RV}-1081 \mathrm{~cm}$ (34 in.) square

$\mathrm{RV}-11100 \mathrm{~cm}$ (40 in.) square

Temperature: 16 to $27 \circ \mathrm{C}(60$ to $80 \circ \mathrm{F})$.

Separate information for the $105-\mathrm{KW}$ fuel storage basin ventilation stacks will not be presented because the information is very similar to that presented for the $105-\mathrm{KE}$ fuel 
storage basin ventilation stacks. Only minor differences in flow rates exist between the $105-\mathrm{KE}$ and $105-\mathrm{KW}$ fuel storage basin ventilation stacks.

\subsubsection{Radiological Liquid Effluents}

The normal liquid emissions from the $105-\mathrm{KE}$ and $105-\mathrm{KW}$ fuel storage basins are conservatively estimated. For the entire $100 \mathrm{~K}$ Area, the releases occur from one liquid discharge point; the 1908-K outfall. The discharge includes raw water filter plant overflow and storage basin cooling water from a system designed to support reactor operations and some area process drain discharges. The 1992 annual flow was $1.0 \times 10^{9} \mathrm{~L}\left(2.8 \times 10^{8} \mathrm{gal}\right)$. The 1992 1908-K outfall radionuclide release activities are presented in Table 3-3 (WHC 1993b).

Planned upgrades to the $105-\mathrm{K}$ Area water supply system (N-027 Project) (WHC 1992a) will reduce the liquid effluent from $1.0 \times 10^{9} \mathrm{~L} /$ year $\left(2.8 \times 10^{8}\right.$ gal/year) to an estimated $2.0 \times 10^{6} \mathrm{~L} /$ year $\left(5.2 \times 10^{5}\right.$ gal/year $)$. The $105-\mathrm{K}$ Area water supply system consists in part of large concrete settling basins (These basins are completely isolated and physically removed from the fuel storage basins) used to remove particulate impurities from river water. Settling basins are located adjacent to both 105-KE and 105-KW areas. Current planning calls for the use of the 105-KW settling basin as a solar evaporation pond, which will eliminate discharge to the river. There is some speculation that Federal, State, and/or Native American wildlife agencies may wish to use the 105-KE Settling basin for fish rearing. Small-scale projects, done in the past and currently ongoing, demonstrate that the $105-\mathrm{KE}$ and 105-KW settling basins can be used for rearing various fish species. Continued discharge from the 1908-KE outfall will be required if the $105-\mathrm{KE}$ settling basin is used for fish rearing.

Table 3-3. Radiological Liquid Effluents from 105-K.

\begin{tabular}{|l|c|c|}
\hline Radionuclide & $\begin{array}{c}\text { Total release } \\
(\mathrm{Ci})\end{array}$ & $\begin{array}{c}\text { Average concentration } \\
(\mu \mathrm{Ci} / \mathrm{Ml})\end{array}$ \\
\hline${ }^{3} \mathrm{H}$ & $2.0 \mathrm{E}-01$ & $1.9 \mathrm{E}-07$ \\
\hline${ }^{60} \mathrm{Co}$ & $3.4 \mathrm{E}-04$ & $3.2 \mathrm{E}-10$ \\
\hline${ }^{90} \mathrm{Sr}$ & $1.2 \mathrm{E}-04$ & $1.1 \mathrm{E}-10$ \\
\hline${ }^{125} \mathrm{Sb}$ & $3.6 \mathrm{E}-04$ & $3.4 \mathrm{E}-10$ \\
\hline${ }^{238} \mathrm{Pu}$ & $2.7 \mathrm{E}-06$ & $2.6 \mathrm{E}-12$ \\
\hline${ }^{239.240} \mathrm{Pu}$ & $1.4 \mathrm{E}-05$ & $1.3 \mathrm{E}-11$ \\
\hline Total $\alpha$ & $2.1 \mathrm{E}-04$ & $2.0 \mathrm{E}-10$ \\
\hline Total $\beta$ & $1.4 \mathrm{E}-03$ & $1.3 \mathrm{E}-09$ \\
\hline
\end{tabular}


WHC-SD-SNF-TI-002, Rev. 0

\subsubsection{Non-Radiological Liquid Effluents}

For the $105-\mathrm{KE}$ and $105-\mathrm{KW}$ operating facilities, the single liquid release point to the Columbia River was reviewed to determine the potential to release hazardous waste. The 1908-K outfall is a permitted National Pollutant Discharge Elimination System outfall, and the analysis performed on this outfall for the permit does not indicate any presence of hazardous waste.

\subsection{BOUNDING ACCIDENT SCENARIOS AND RELATED ENVIRONMENTAL RELEASES}

Safety analyses have been performed for all fuel storage facilities at the Hanford Site. Potential accident scenarios and frequencies of occurrence are developed as a part of the safety analyses documentation. All accidents which occur with a frequency greater than once every million years are considered to be credible. The evaluated credible accident with the largest consequence to onsite and/or offsite receptors is considered to be the bounding accident. For the purpose of this document, four bounding accidents were considered (1) radiological airborne release, (2) nonradiological airborne release, (3) radiological liquid release, and (4) nonradiological liquid release (WHC 1993b, WHC 1991b, and WHC 1992c).

The tabulated releases included in this document are based on accident analyses developed prior to 1994. In 1994, concerns were raised that these releases may not be bounding. The values included within this document will be revised should on-going or future analyses indicate substantially different results.

\subsubsection{Radiological Airborne Release Accident}

The radiological airborne release scenario assumes that a shipping cask drops from a crane onto a hard surface and ruptures exposing all of the broken fuel elements in three canisters (42 irradiated fuel elements each containing $50 \mathrm{lb}$ of fuel) (Smith 1991, WHC 1993d). The analysis assumes 10-year-old fuel-grade plutonium (12 percent of plutonium content is $\left.{ }^{240} \mathrm{Pu}\right)$. The inventory at risk is calculated to be $3.4 \mathrm{E}+03 \mathrm{~g}(7.5 \mathrm{lb})$. The source term is calculated by multiplying the inventory at risk by the release fraction. The calculation of the release fraction assumes the fuel heats but does not melt. Also, credit is taken for evacuation of onsite workers (two hours for the onsite calculation of a release factor). The offsite calculation of a release factor was made using an eight-hour release time. The calculated release factors are 0.018 for onsite and 0.072 for offsite. 
The specific isotopic releases are (in Curies):

\begin{tabular}{lll} 
Isotope & Onsite $(61 \mathrm{~g})$ & Offsite $(244 \mathrm{~g})$ \\
\cline { 2 - 3 }${ }^{236} \mathrm{Pu}$ & $1.3 \mathrm{E}-08$ & $1.4 \mathrm{E}-08$ \\
${ }^{238} \mathrm{Pu}$ & $2.9 \mathrm{E}-03$ & $1.2 \mathrm{E}-02$ \\
${ }^{239} \mathrm{Pu}$ & $6.7 \mathrm{E}-03$ & $2.7 \mathrm{E}-02$ \\
${ }^{240} \mathrm{Pu}$ & $3.5 \mathrm{E}-03$ & $1.4 \mathrm{E}-02$ \\
${ }^{241} \mathrm{Pu}$ & $2.7 \mathrm{E}-01$ & $1.1 \mathrm{E}+00$ \\
${ }^{424} \mathrm{Pu}$ & $1.3 \mathrm{E}-06$ & $5.1 \mathrm{E}-06$ \\
${ }^{241} \mathrm{Am}$ & $5.7 \mathrm{E}-03$ & $2.3 \mathrm{E}-02$ \\
${ }^{244} \mathrm{Cm}$ & $2.8 \mathrm{E}-04$ & $1.1 \mathrm{E}-03$ \\
${ }^{154} \mathrm{Eu}$ & $5.4 \mathrm{E}-03$ & $2.1 \mathrm{E}-02$ \\
${ }^{134} \mathrm{Cs}$ & $7.9 \mathrm{E}-03$ & $3.2 \mathrm{E}-02$ \\
${ }^{137} \mathrm{Cs}$ & $4.5 \mathrm{E}-01$ & $1.8 \mathrm{E}+00$ \\
${ }^{144} \mathrm{Ce}$ & $1.7 \mathrm{E}-03$ & $6.8 \mathrm{E}-03$ \\
${ }^{144} \mathrm{Pr}$ & $1.7 \mathrm{E}-03$ & $6.8 \mathrm{E}-03$ \\
${ }^{1444} \mathrm{Pr}$ & $2.0 \mathrm{E}-05$ & $8.1 \mathrm{E}-05$ \\
${ }^{147} \mathrm{Pm}$ & $1.2 \mathrm{E}-01$ & $4.9 \mathrm{E}-01$ \\
${ }^{125} \mathrm{Sb}$ & $7.3 \mathrm{E}-03$ & $2.9 \mathrm{E}-02$ \\
${ }^{125 \mathrm{M} T e}$ & $1.8 \mathrm{E}-03$. & $7.3 \mathrm{E}-03$ \\
${ }^{106} \mathrm{Ru}$ & $3.2 \mathrm{E}-03$ & $1.3 \mathrm{E}-02$ \\
${ }^{90} \mathrm{Sr}$ & $3.5 \mathrm{E}-01$ & $1.4 \mathrm{E}+00$ \\
${ }^{90} \mathrm{Y}$ & $3.5 \mathrm{E}-01$ & $1.4 \mathrm{E}+00$
\end{tabular}

\subsubsection{Non-Radiological Airborne Release}

Safety Evaluation of Fuel Encapsulation in the 105-KE Storage Basin (WHC 1992c) contains an accident scenario involving the release of chlorine from the 105-KE fuel storage basin facility. At the time the document was written, 910-kg (1-metric-ton) chlorine cylinders were used at the $105-\mathrm{KE}$ fuel storage basin. The $910-\mathrm{kg}$ cylinders have been replaced by $45-\mathrm{kg}$ (100-lb) cylinders; therefore, the current accident analysis is no longer valid. An interim safety basis is currently being written which will reevaluate the chlorine release issue.

Because of the remote nature of the facility and the small chlorine inventory, a postulated accidental release of chlorine is unlikely to result in harm to any offsite individual.

\subsubsection{Radiological Liquid Release}

The bounding liquid release from the pool has been postulated in Safety Analysis Irradiated N Reactor Fuel (WHC 1993d) based on an $20 \mathrm{~cm}$ (8 in.) water supply pipe breaking inside of the pool building and releasing $7,600 \mathrm{~L} / \mathrm{min}(2,000 \mathrm{gal} / \mathrm{min})$ into the pool. The flow is not shut off for 8 hours, resulting in a $2.3 \times 0^{6}-\mathrm{L}(600,000$-gal) overflow from 
the pool, which forms a shallow $2.6 \times 10^{4}-\mathrm{m}^{2}(6.4$-acre) lake in the area. As a conservative assumption, the basin water overflow contains 61 percent of the basin water radionuclide inventory. The bounding liquid release from the storage pool during storage is estimated at $34 \mathrm{Ci}$, based on the updated radionuclide inventory in Facility Effluent Monitoring Plan Determinations for the 100 Area Facilities (WHC 1991c). Specific radionuclides released are:

\begin{tabular}{|c|c|}
\hline Radionuclide & Emission (Ci) \\
\hline${ }^{3} \mathrm{H}$ & $1.3 \mathrm{E}+01$ \\
\hline${ }^{54} \mathrm{Mn}$ & 3.8 E-02 \\
\hline $\begin{array}{l}{ }^{60} \mathrm{Co} \\
-1\end{array}$ & $2.9 \mathrm{E}-02$ \\
\hline${ }^{90} \mathrm{Sr}$ & $9.2 \mathrm{E}+00$ \\
\hline${ }^{125} \mathrm{Sb}$ & $9.2 \mathrm{E}-02$ \\
\hline $\begin{array}{l}1344 \mathrm{Cs} \\
130\end{array}$ & $4.2 \mathrm{E}-02$ \\
\hline${ }^{137} \mathrm{Cs}$ & $1.2 \mathrm{E}+01$ \\
\hline${ }^{238} \mathrm{Pu}$ & $9.8 \mathrm{E}-03$ \\
\hline${ }^{239} \mathrm{Pu}$ & $5.6 \mathrm{E}-02$ \\
\hline
\end{tabular}

\subsubsection{Non-Radiological Liquid Release}

Nonradiological liquid release accidents were not postulated in the SAR. Because of the remote nature of the facility and its small inventory of nonradiological hazardous materials, a postulated accidental release of any of the hazardous materials at the facility is unlikely to result in harm to any offsite individual. 
WHC-SD-SNF-TI-002, Rev. 0

This page intentionally left blank. 
WHC-SD-SNF-TI-002, Rev. 0

\subsection{FAST FLUX TEST FACILITY}

\subsection{GENERAL INFORMATION}

The FFTF consists of a liquid-sodium-cooled reactor, several closed-loop systems, and numerous supporting facilities located in the 400 Area of the Hanford Site. The purpose of FFTF was to provide testing capability to satisfy the diverse technological needs of the United States advanced reactor programs. To meet the goals of the various test programs, the reactor was capable of simulating the irradiation conditions of a full-scale commercial liquid-metal reactor. In addition, the core component configuration within the reactor was capable of being routinely redesigned. Components can be relocated within the core or replaced with different components (irradiated or unirradiated) from outside the core. In April 1992, the DOE placed the FFTF in a hot standby condition. In December 1993, the DOE decided to shut down FFTF before eventual decontamination and decommissioning. FFTF is shown schematically in Figures 4-1 through 4-4.

\subsection{IRRADIATED FUEL STORAGE AT FFTF}

FFTF irradiated fuel is stored within several different facilities including the reactor core, the in-vessel storage (IVS), the interim decay storage (IDS), and the FSF. Some irradiated fuel pins have been shipped offsite for detailed examination and a few assemblies are temporarily located within the IEM cell while they are examined. Most irradiated fuel remains in the original assemblies; however, some irradiated fuel (that remaining after the disassembly and shipment of fuel pins offsite) is stored in pin containers of similar outside dimensions as the assemblies. Irradiated fuel is handled remotely, and irradiated fuel within the reactor core, the IVS, the IDS, and the FSF are cooled with liquid sodium. Assemblies can be routinely moved between the reactor core, the IVS and the IDS; but once placed in the FSF, previously irradiated fuel assemblies have not been reinserted into the reactor.

The reactor contains the fueled and nonfueled assemblies, and provides radiation shielding, cooling, and instrumentation to allow safe operation. The reactor is also equipped with instrumentation which permits monitoring of assembly temperature and coolant flow, but is not part of the plant safety system.

\subsubsection{Reactor Core}

The reactor core contains fueled, nonfueled, and control rod assemblies, as well as radial reflectors and shield components, which function together to create a controlled, fast neutron environment. The core consists of nine rows of vertical elements arranged in a 


\section{WHC-SD-SNF-TI-002, Rev. 0}

Figure 4-1. Fast Flux Test Facility.

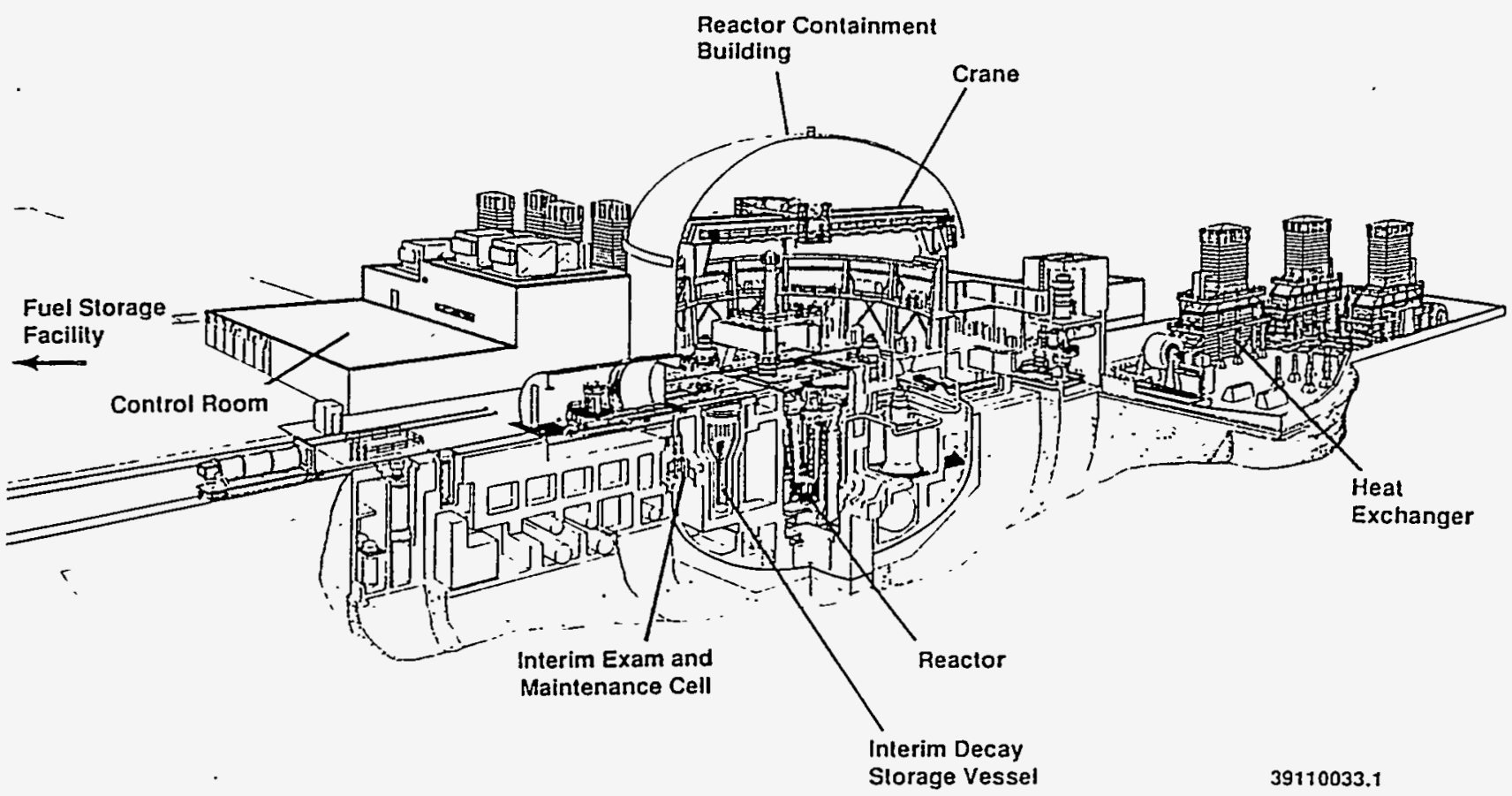


Figure 4-2. Fast Flux Test Facility Reactor Core.

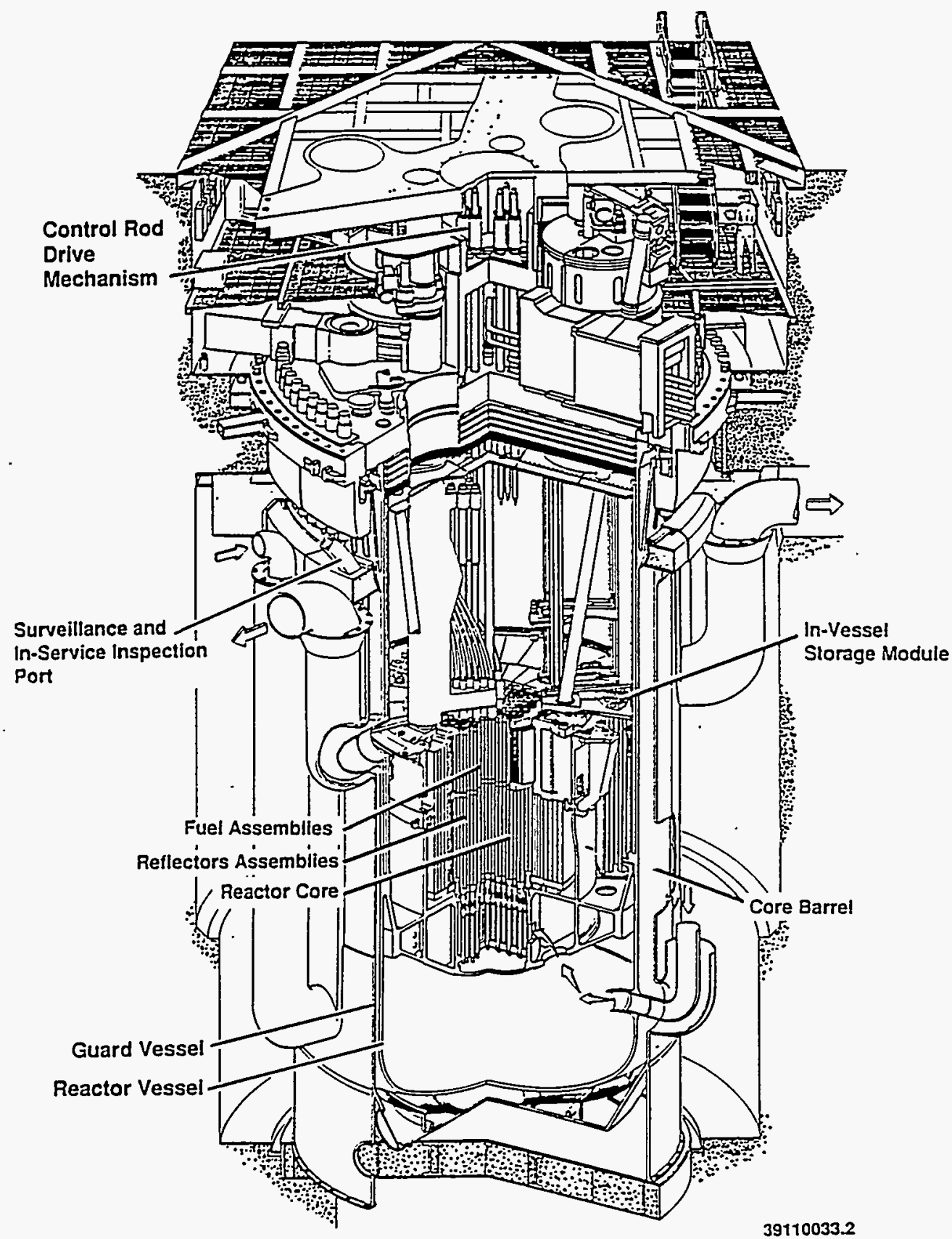




\section{WHC-SD-SNF-TI-002, Rev. 0}

Figure 4-3. Interim Decay Storage Vessel.

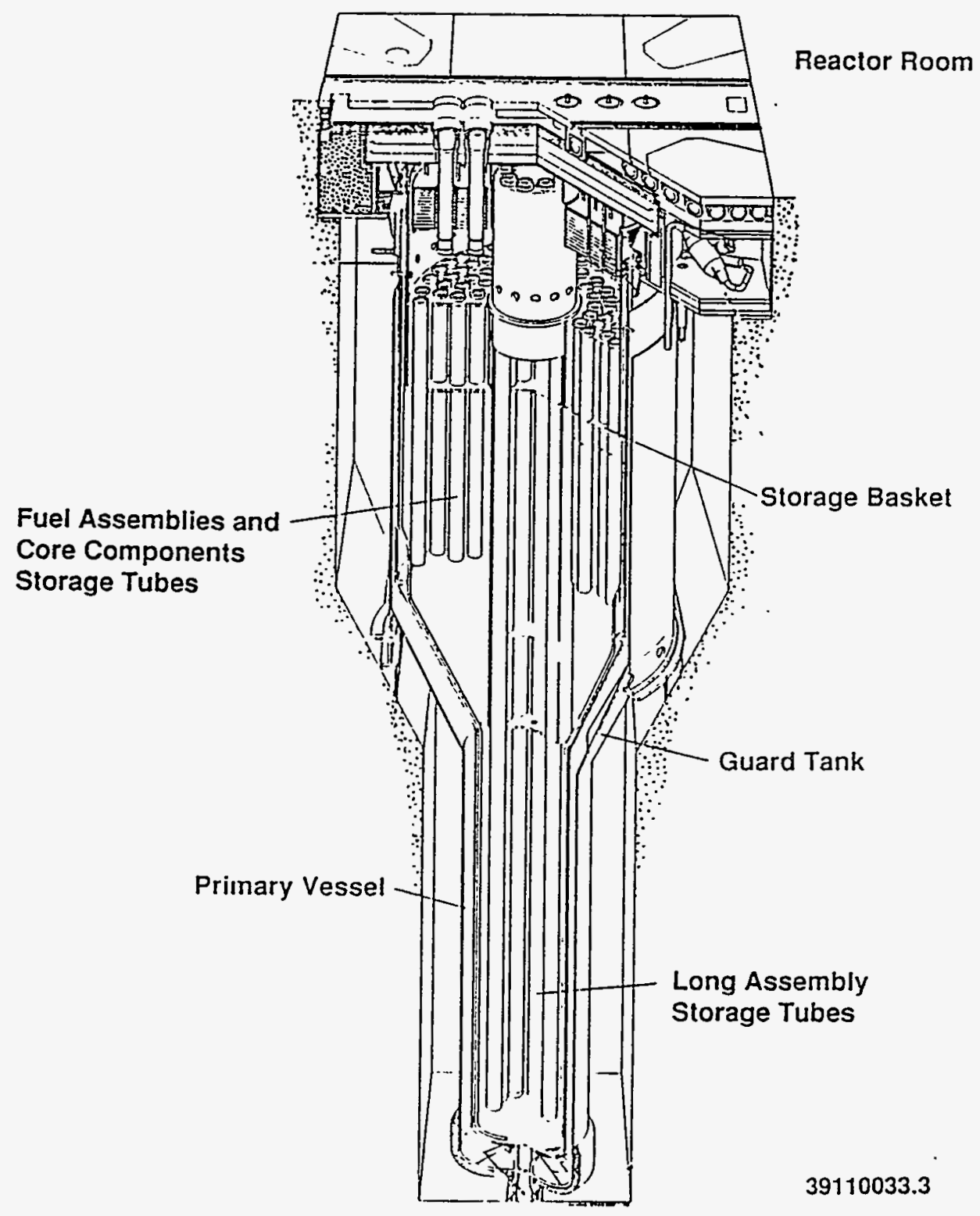


WHC-SD-SNF-TI-002, Rev. 0

Figure 4-4. Fuel Storage Facility.

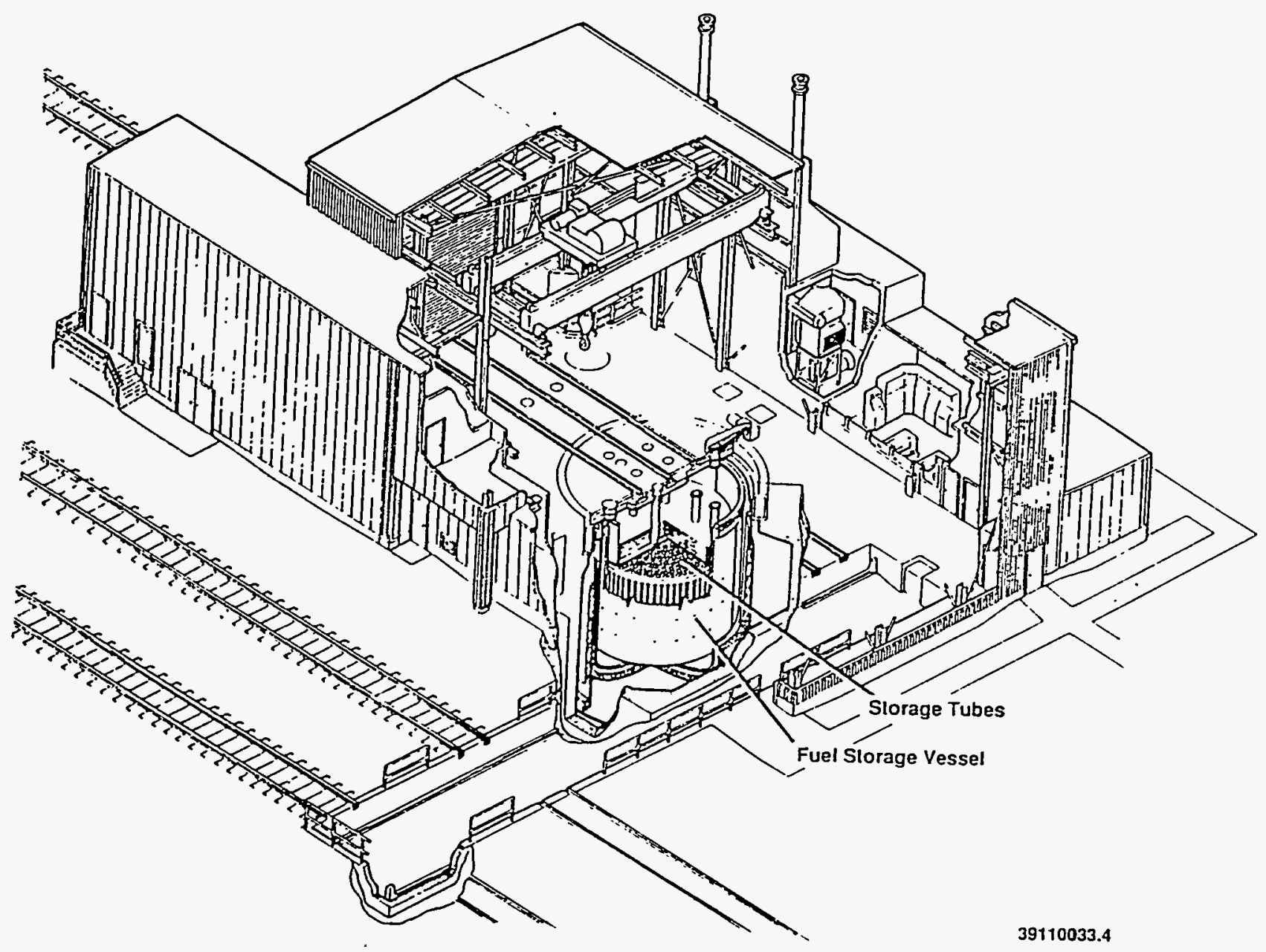


hexagonal array. The active zone consists of the 91 positions of the six inner rows. The number of assemblies which can be loaded into the active zone is determined on a case-bycase basis. The active zone is surrounded by three rows of reflector assemblies.

\subsubsection{In-Vessel Storage}

The IVS is located within the reactor vessel but outside of the core region. Fuel stored in the IVS enables the reactor core to be reconfigured during an operating cycle without opening the reactor vessel. The IVS consists of three storage modules within the reactor, each serving one-third of the reactor core. Each module provides 19 naturalcirculation, sodium-cooled receptacles for core components. Each IVS module consists of a top and bottom plate welded together with an elliptically shaped body. The storage receptacles are cylindrical tubes supported by the top and bottom plates. Heat rejection is through the same primary and secondary coolant systems that service the reactor core. These coolant systems contain approximately $725,000 \mathrm{~L}(192,000 \mathrm{gal})$ of sodium.

\subsubsection{Interim Decay Storage}

The IDS is located within the reactor containment building but outside of the reactor vessel. It provides a controlled environment for temporary storage of irradiated fuel and other core components between irradiations in the reactor core. The IDS also provides temporary storage of new assemblies and other core components enroute to the reactor. The IDS is in a rectangular, steel-lined concrete cell. The IDS consists of a rotatable storage basket contained in a sodium-filled, argon-inerted, stainless steel primary vessel. The liquid sodium cooling system in the IDS is separate and independent from the reactor vessel sodium system. A carbon steel guard tank surrounds the primary vessel to help ensure adequate sodium cooling even if the primary vessel leaks. The atmosphere outside the primary vessel, but within the concrete cell, is nitrogen which also serves as a heat transfer medium to control the cell temperature.

There are 122 storage positions for fueled components and other core components, arranged in five concentric circles. The outer four circles can store 112 of the $3.7-\mathrm{m}-$ (12-ft-) long core components while the inner circle can store ten special $12-\mathrm{m}$ - (39-ft-) long nonfueled assemblies. In order to accommodate these different length assemblies, the IDS has a relatively small cylindrical lower section connected to a larger upper section. The lower cylinder is approximately $6 \mathrm{~m}(20 \mathrm{ft})$ long and $1.5 \mathrm{~m}(5 \mathrm{ft})$ in diameter. The upper section is a cylinder $3.8 \mathrm{~m}(12.5 \mathrm{ft})$ long and $3.7 \mathrm{~m}(12 \mathrm{ft})$ in diameter. The transition between these sections is a conical section approximately $2 \mathrm{~m}(7 \mathrm{ft})$ long. The primary vessel contains approximately $75,000 \mathrm{~L}(20,000 \mathrm{gal})$ of sodium.

The decay heat of an assembly placed in the IDS must be no greater than $10 \mathrm{Kw}$, while the total inventory decay heat is limited to $155 \mathrm{Kw}$. Decay heat is dissipated by either the primary sodium system for the IDS or the backup nitrogen cooling system. 


\subsubsection{Fuel Storage Facility.}

The FSF is located at the FFTF in a separate building from the reactor containment building. It provides a controlled environment for longer-term storage of irradiated fueled components and other core components. The FSF consists of a primary storage vessel, two closed-loop systems, and supporting facilities. The irradiated fuel is held in a rotatable cooling/storage rack contained in a sodium-filled, argon-inerted, carbon steel primary vessel. A surrounding carbon steel guard tank ensures adequate sodium containment and cooling in the event of a primary vessel leak. The FSF is housed in a building of standard industrial above-grade construction and reinforced concrete below-grade construction.

The primary vessel contains 466 positions for assemblies and Ident 69 containers (containers of irradiated fuel pins from disassembled assemblies) arranged in concentric circles, although only 380 are currently usable because of criticality considerations. The

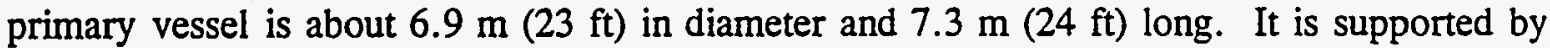
a flange at the top and contains about $120,000 \mathrm{~L}(32,000$ gal) of sodium. The decay heat of an assembly placed in the FSF must be no greater than $1.4 \mathrm{Kw}$.

Decay heat is removed from the stored materials by natural circulation of the vessel sodium. The sodium transfers heat to two separate sodium-potassium heat transfer loops, which reject the heat to the atmosphere through a natural draft heat exchanger in each loop. Each loop has a heat removal capacity of $205 \mathrm{Kw}$.

The FSF is designed to interface with the FFTF fuel-handling equipment to facilitate insertion and removal of fueled and nonfueled core components, as are all the FFTF facilities where irradiated fuel is held. The FSF makes use of the bottom-loading transfer cask and the FFTF floor valve for these operations.

A small number of irradiated fuel pins leak cesium and other contaminants into the sodium coolant. The contaminants are removed from the sodium by a cold trap in the FSF sodium system.

\subsubsection{Dry Storage at FFTF}

Additional storage capacity at the FFTF has been requested to support early shutdown of the sodium-cooled storage facilities. Approval has been given for the design and construction of ten interim storage casks for the dry storage of sixty fueled components. The interim storage cask design is capable of storing six assemblies. The interim storage casks will be approximately $4.6 \mathrm{~m}(15.5 \mathrm{ft})$ tall, $2.3 \mathrm{~m}(7.5 \mathrm{ft})$ in outside diameter and weigh 54 metric tons (60 tons). The internal cavity is expected to be approximately $3.8 \mathrm{~m}(12.5 \mathrm{ft}$ ) high and $53 \mathrm{~cm}(21 \mathrm{in}$.$) in diameter.$ 
Irradiated fuel assemblies with sufficient reactor exposure to meet security qualifications for self-protection and with decay heats of $250 \mathrm{~W}$ or less would be removed from sodium-cooled storage, flushed with water vapor or argon and water to remove the sodium (at most, a few grams will remain), and placed into an interim storage cask for interim storage.

Approximately 60 casks would be required for the current inventory of irradiated fuel assemblies. The casks would be stored above ground on an existing concrete pad at the FFTF, with naturally convected air providing the necessary cooling, at least until issuance of the record of decision for the site-specific EIS for spent nuclear fuels.

\subsection{FUEL TRANSPORTATION}

Unirradiated fuel was transported to FFTF by truck. FFTF has access to both truck and rail transportation.

\subsection{ESTIMATED STAFF SIZE AND OPERATIONAL COST}

\subsubsection{Estimated Staff Size}

For the next five years FFTF will be involved in shutdown activities. During this shutdown period, approximately 400 full-time staff will be required. The staff includes operators, engineers, managers and supervisors, craftspersons, secretarial/clerical, work control, health physics technicians, and numerous other skill areas.

Following shutdown activities, the site-specific fuels EIS will provide the final determination for interim storage of irradiated FFTF fuels; however, current planning (WHC 1994b) calls for the following:

- Irradiated FFTF fuel removed from sodium, placed in interim storage casks, and stored dry on a pad in either 400 or 200 Areas.

- Sodium systems drained and inerted and the sodium stored in the 400 Area. Only systems required to maintain sodium inert, and allow inspection of the balance of the plant remain in operation.

- Unirradiated fuel transferred to the Plutonium Finishing Plant. 
Significant assumptions for current plans are:

- Plant and FSF sodium systems can be drained to storage tanks in the protected area, and those systems be maintained inert.

- Plant systems are secured, but preserved in anticipation of future use, and survèillance requirements (technical specifications, criticality safety specifications, etc.) are accordingly reduced.

- With only irradiated fuel stored in the 400 Area, the area can be downgraded to a property protection area. The estimated size of the security force reflects this change.

The estimated staff size required in this scenario is 51 , detailed as follows:

- FFTF Plant has a direct staff of 28 , including all staff required to maintain and administer the plant. A breakdown of the types of personnel is unavailable.

- Security has an indirect staff of 20 , including the security force and administration.

- Program has a direct staff of 3, including staff required for program-related functions. A breakdown of the types of personnel is unavailable.

\subsubsection{Estimated Operational Cost}

The estimated operational cost for FFTF is estimated to be approximately $\$ 55$ million each year for the next five years. This cost estimate is based on shutdown activities. The estimated operational cost following shutdown is $\$ 13$ million in 1994 dollars. The cost for interim storage casks is estimated at $\$ 25$ million in 1994 dollars.

\subsection{ESTIMATED OPERATIONAL DOSE COMMITMENT}

The operational dose commitment at FFTF is very low (estimated to be less than 1 man-rem each year spread over 500 workers). The operational dose commitment may be increased somewhat when the irradiated fuel is transferred, but is still expected to be negligible. 
WHC-SD-SNF-TI-002, Rev. 0

\subsection{ESTIMATED ROUTINE ENVIRONMENTAL RELEASES} follows:

The estimated environmental releases have been divided into four categories as

- Radiological airborne emissions

- Nonradiological airborne emissions

- Radiological liquid effluents

- Nonradiological liquid effluents.

\subsubsection{Radiological Airborne Emissions}

Airborne radiological releases from the operation of FFTF for calendar years 1990 , 1991, and 1992, including fuel storage operations, are presented in Table 4-1. Radionuclide air emissions for FFTF-CB-EX combined exhaust. This stack exhausts normally unfiltered air from the reactor containment and gases from the argon processing system, including offgas from the fuel storage vessel. Standby particulate filters can be manually dampered into the system if airborne radioactive particulate levels rise above certain concentrations. Emissions monitoring consists of a record sampler, a beta continuous air monitor, and a noble gas monitor.

Table 4-1. Radiological Airborne Emissions from FFTF.

\begin{tabular}{|l|c|c|c|}
\hline Radionuclide & $\begin{array}{c}1992 \text { totals (Ci) } \\
\text { (DOE-RL 1993b) }\end{array}$ & $\begin{array}{c}1991 \text { totals (Ci) } \\
\text { (DOE-RL 1992) }\end{array}$ & $\begin{array}{c}1990 \text { totals (Ci) } \\
\text { (DOE-RL 1991) }\end{array}$ \\
\hline${ }^{3} \mathrm{H}$ & Not available & Not available & $2.9 \mathrm{E}+00 \mathrm{Ci}$ \\
\hline${ }^{41} \mathrm{Ar}$ & $8.5 \mathrm{E}+00 \mathrm{Ci}$ & $2.7 \mathrm{E}+01 \mathrm{Ci}$ & $2.9 \mathrm{E}+01 \mathrm{Ci}$ \\
\hline${ }^{137} \mathrm{Cs}$ & Not available & $2.1 \mathrm{E}-06 \mathrm{Ci}$ & $4.8 \mathrm{E}-07 \mathrm{Ci}$ \\
\hline Total alpha ${ }^{\mathrm{a}}$ & $1.1 \mathrm{E}-06 \mathrm{Ci}$ & Not available & Not available \\
\hline Total beta & $6.7 \mathrm{E}-06 \mathrm{Ci}$ & Not available & Not available \\
\hline Total flow & $3.6 \mathrm{E}+08 \mathrm{~m}^{3}$ & $3.6 \mathrm{E}+08 \mathrm{~m}^{3}$ & $3.4 \mathrm{E}+08 \mathrm{~m}^{3}$ \\
\hline
\end{tabular}

${ }^{3}$ Total alpha and total beta counts are for particulate only.

\subsubsection{Non-Radiological Airborne Emissions}

There is no routine monitoring of nonradioactive releases for FFTF. Any routine releases which might occur have not been considered to be significant, and therefore no constiruents are measured. 


\subsubsection{FFTF Stack Information (DOE-RL $1993 \mathrm{~b}$ and WHC 1993b)}

The only effluent source for irradiated fuel storage areas is the cell atmosphere processing system. The effluent is discharged, along with many other effluent sources, from the main stack. This effluent point combines the offgas from the heating, ventilating, and air-conditioning system $\left(600,000 \mathrm{~L} / \mathrm{min}\left[20,000 \mathrm{ft}^{3} / \mathrm{min}\right]\right)$, the access control area exhaust $\left(100,000 \mathrm{~L} / \mathrm{min}\left[4,000 \mathrm{ft}^{3} / \mathrm{min}\right]\right)$, the cell atmosphere processing system $(850 \mathrm{~L} / \mathrm{min}$ [30 $\left.\left.\mathrm{ft}^{3} / \mathrm{min}\right]\right)$, and the radioactive argon processing system $\left(160 \mathrm{~L} / \mathrm{min}\left[5.7 \mathrm{ft}^{3} / \mathrm{min}\right]\right)$. The cell atmosphere processing system is only 0.1 percent of the combined offgas volume. The following information applies to the entire FFTF facility.

Stack height: $14.3 \mathrm{~m}(46.9 \mathrm{ft})$

Flow rate: $68,000 \mathrm{~L} / \mathrm{min}\left(24,000 \mathrm{ft}^{3} / \mathrm{min}\right)$ for the combined exhaust point Diameter: Exhausted horizontally from a $120 \times 120-\mathrm{cm}(48 \times 48$-in.) duct Temperature: Ambient temperature of approximately $20 \circ \mathrm{C}(70 \circ \mathrm{F})$.

\subsubsection{Radiological Liquid Effluents} FFTF.

There are no routine liquid effluent streams resulting from irradiated fuel storage at

\subsubsection{Non-Radiological Liquid Effluents} FFTF.

There are no routine liquid effluent streams resulting from irradiated fuel storage at

\subsection{BOUNDING ACCIDENT SCENARIOS AND RELATED ENVIRONMENTAL RELEASES}

Safety analyses have been performed for all irradiated fuel storage facilities at the Hanford Site. Potential accident scenarios and frequencies of occurrence are developed as a part of the safety analyses documentation. All accidents which occur with a frequency greater than once every million years are considered to be credible. The evaluated credible accident with the largest consequence to onsite and/or offsite receptors is considered to be the bounding accident. For the purpose of this document, four bounding accidents were considered (1) radiological airborne release, (2) nonradiological airborne release, (3) radiological liquid release, and (4) nonradiological liquid release. A detailed description of each accident scenario evaluated for the FSF is available in WHC-EP-0132 (WHC 1989). 


\subsubsection{Radiological Airborne Accident Scenario}

The accident scenario for the handling and storage of irradiated FFTF fuel in the FSF is a spill of $11,793 \mathrm{~kg}(26,000 \mathrm{lb})$ of liquid sodium followed by a fire which consumes the spilled sodium. The spill is initiated by a seismic event which causes a break in the piping between the FSF and heat exchangers. The liquid sodium is assumed to auto ignite and burn releasing aerosols to the atmosphere.

This dose rate comes from cesium which has been leached from the irradiated fuel into the sodium. It is assumed for this accident that 3 percent of the elements are breached and that the sodium contains $27 \mu \mathrm{Ci}-{ }^{134} \mathrm{Cs} / \mathrm{g}-\mathrm{Na}$ and $150 \mu \mathrm{Ci}-{ }^{137} \mathrm{Cs} / \mathrm{g}-\mathrm{Na}$. 35 percent of the sodium and cesium aerosols released in the fire are assumed to be released to the atmosphere. Hence the total activity released is $111 \mathrm{Ci}^{134} \mathrm{Cs}$, and $619 \mathrm{Ci}^{137} \mathrm{Cs}$ (WHC 1989). This issue was recently revisited (Van Keuren 1994). In the latest evaluation, the concentrations are reestimated at $0.9 \mu \mathrm{Ci}-{ }^{134} \mathrm{Cs} / \mathrm{g}-\mathrm{Na}$ and $5 \mu \mathrm{Ci}-{ }^{137} \mathrm{Cs} / \mathrm{g}-\mathrm{Na}$, and the totals released to the atmosphere are $3.7 \mathrm{Ci}{ }^{134} \mathrm{Cs}$ and $25 \mathrm{Ci}{ }^{137} \mathrm{Cs}$.

The predicted consequences of this accident are as follows (WHC 1989):

Offsite
\begin{tabular}{lll} 
Whole & (mrem) \\
Whole & \\
Body & Skin & Lung \\
\hline 15 & 16 & 3
\end{tabular}

Onsite
$\begin{aligned} & \text { Wose } \\
& \text { Whole }\end{aligned}$
\begin{tabular}{lcc} 
Body & Skin & Lung \\
\hline 72 & 79 & 11
\end{tabular}

\begin{tabular}{|c|c|c|}
\hline \multicolumn{3}{|c|}{ In FSF (mrem) } \\
\hline Whole & & \\
\hline Body & Skin & Lung \\
\hline 19,200 & 23,600 & 2,880 \\
\hline
\end{tabular}

\subsubsection{Non-Radiological Airborne Accident Scenario}

In the same scenario as the accident in the radiological airborne accident scenario above, namely a sodium leak and subsequent fire, one of the primary combustion products from the fire is sodium oxide. The sodium oxide combustion product will combine with the water in the air to form sodium hydroxide aerosols. Approximately 35 percent of the burned sodium is assumed to be released to the atmosphere for a total of about $10,500 \mathrm{~kg}$ $(23,100 \mathrm{lb})$ of $\mathrm{NaOH}$ aerosols. The maximum sodium aerosol concentration at the site boundary would be $8.5 \mathrm{mg}(\mathrm{NaOH}) / \mathrm{m}^{3}$ during the first eight hours, reducing to $<1 \mathrm{mg}$ $(\mathrm{NaOH}) / \mathrm{m}^{3}$ after twenty-four hours (WHC 1989).

\subsubsection{Radiological and Non-Radiological Liquid Accident Scenarios}

No radiological nor nonradiological liquid accidents were credible. 
WHC-SD-SNF-TI-002, Rev. 0

\subsection{T PLANT}

\subsection{GENERAL INFORMATION}

The T Plant complex was constructed in the mid-1940's to extract plutonium from spent reactor fuel using the bismuth phosphate process. T Plant performed this function until it was deactivated in 1956. Most of the original process equipment was subsequently removed. In 1957, $\mathrm{T}$ Plant was placed in service as a beta-gamma decontamination facility. T Plant irradiated fuel storage is shown schematically in Figures 5-1 through 5-4.

The T Plant complex is composed of several buildings and support facilities located in the northeast corner of the 200 West Area of the Hanford Site. The main structure is the 221-T Canyon Building. The building is a reinforced-concrete canyon facility approximately $260 \mathrm{~m}(850 \mathrm{ft})$ long $\times 21 \mathrm{~m}(69 \mathrm{ft})$ wide $\times 23 \mathrm{~m}(55 \mathrm{ft})$ high and covers an area of approximately $5,400 \mathrm{~m}^{2}$ (1.3 acres). The major features of the building include the canyon, three galleries (operating, pipe, and electrical), one craneway, and a "headend" facility.

The canyon area consists of 37 cells and one railroad tunnel entrance/exit. The cells are paired into $12-\mathrm{m}-(39-\mathrm{ft}-)$ wide sections arranged in a single row running the length of the building. The canyon deck is about $12 \mathrm{~m}(39 \mathrm{ft})$ below a $1-\mathrm{m}-(3-\mathrm{ft}-)$ thick concrete roof. The railroad tunnel is used for transporting equipment into and out of the canyon, and enters through a $4.5-\mathrm{m}-(15-\mathrm{ft}-)$ wide $\times 6.7-\mathrm{m}-(22-\mathrm{ft}-)$ high opening. The opening is covered by a motor-driven rolling steel door. Overhead cranes with capacities of 40 and 9 metric tons (45 and 10 tons) are used to transport materials inside the facility.

Shielding walls made of $2.7-\mathrm{m}$ - (9-ft-) thick reinforced concrete separate the canyon cells from the electrical and pipe galleries. The operating gallery is separated from the canyon deck by a $2.1-\mathrm{m}-(7-\mathrm{ft}-)$ thick reinforced-concrete wall. Most of the cells are covered by four $1.8-\mathrm{m}-(6-\mathrm{ft}-)$ thick reinforced-concrete blocks. The cells are separated from each other by $2.1-\mathrm{m}-(7-\mathrm{ft}-)$ thick reinforced-concrete walls.

\subsection{IRRADIATED SHIPPINGPORT PWR CORE II FUEL STORAGE AT T PLANT}

The cell adjacent to the railroad tunnel contains a 4-m- (13-ft-) wide $\times 8.4-\mathrm{m}-(28-\mathrm{ft}-)$ long $\times 8.5-\mathrm{m}-(28-\mathrm{ft}-)$ deep pool with a capacity of about $190,000 \mathrm{~L}(50,000 \mathrm{gal})$. The pool cell was modified for the storage of the Shippingport PWR Core II irradiated fuel. This concrete cell has a fabric liner between white concrete and grey reinforced concrete. A catwalk is placed $1.5 \mathrm{~m}(5 \mathrm{ft})$ above the pool to allow access to the pool for sampling and maintenance. All irradiated fuel handling must be done remotely. Filtered, demineralized 
WHC-SD-SNF-TI-002, Rev. 0

Figure 5-1. T Plant Complex.

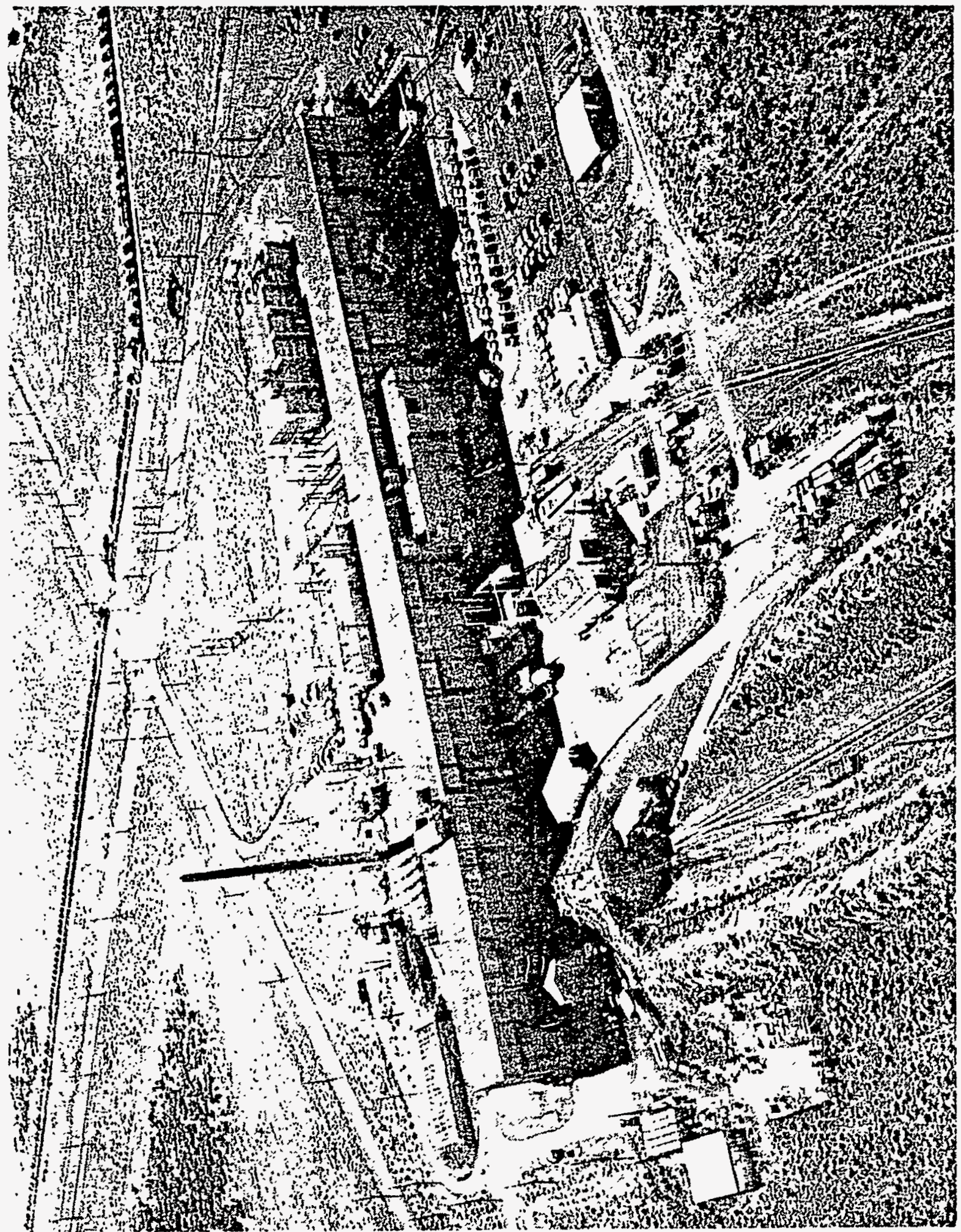


WHC-SD-SNF-TI-002, Rev. 0

Figure 5-2. 221-T Canyon Building Cutaway View.

\section{T Plant Cutaway}

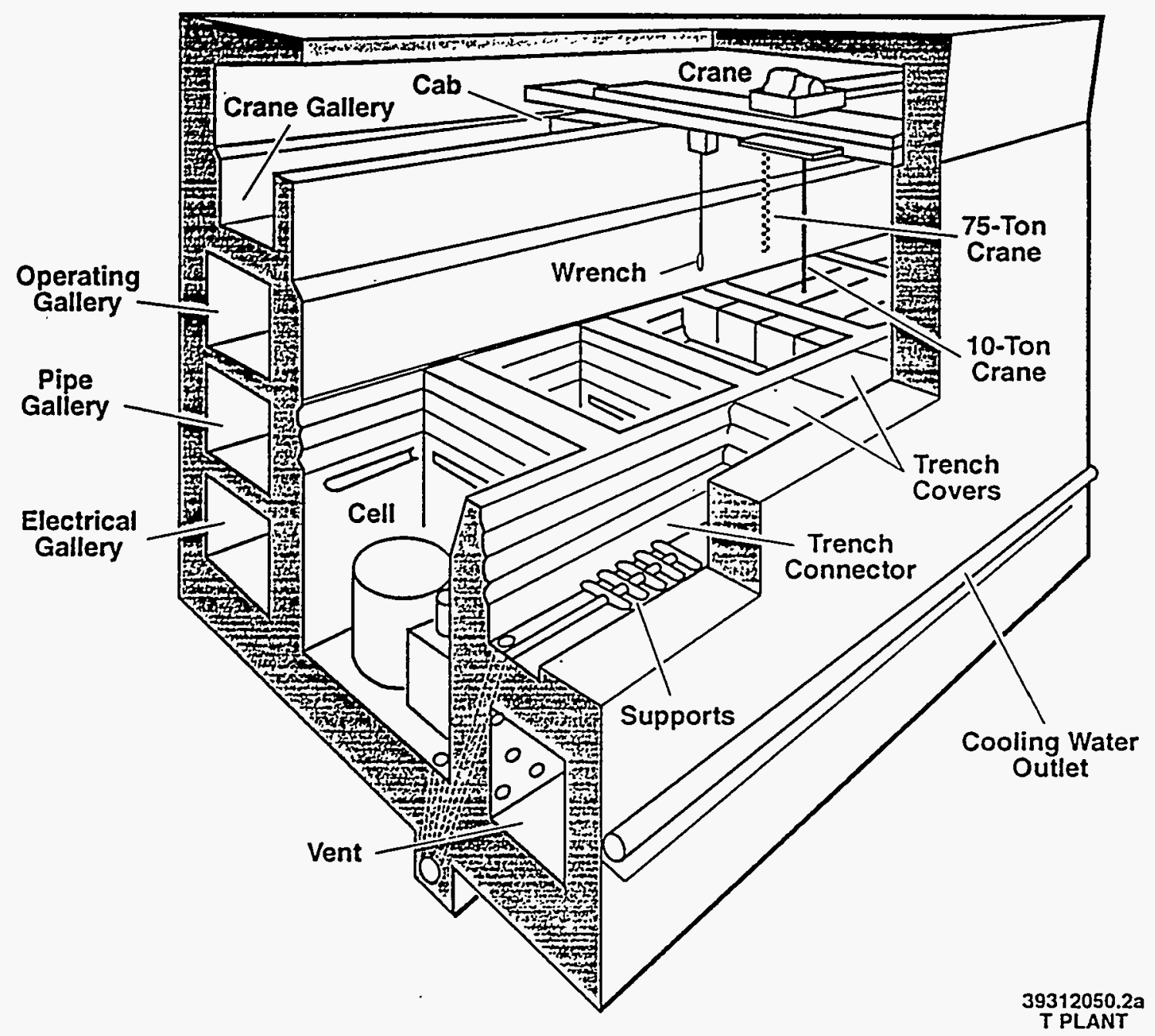


WHC-SD-SNF-TI-002, Rev. 0

Figure 5-3. Shippingport PWR Core II Fuel Storage at T Plant.

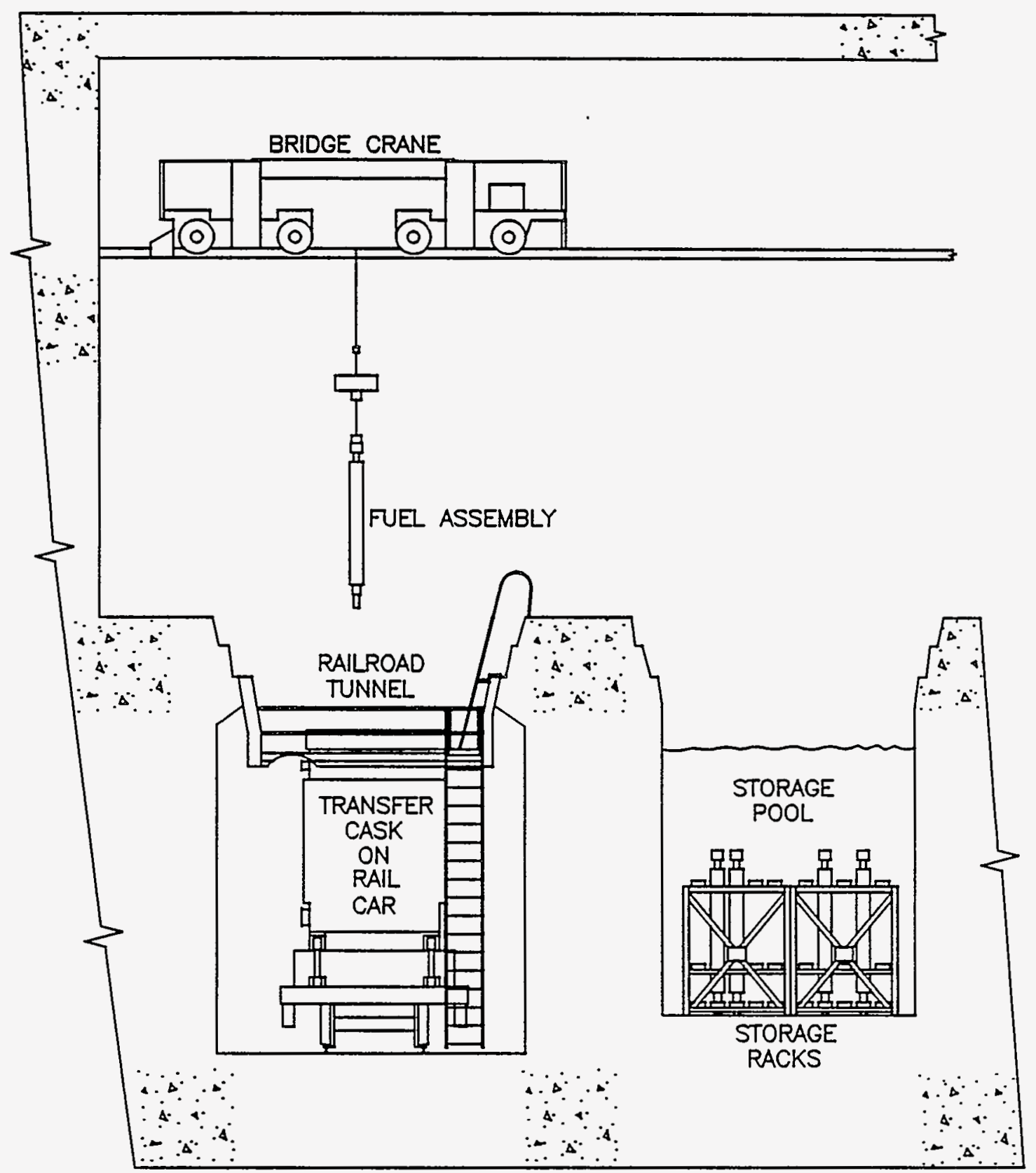

SHIPPINGPORT CORE II FUEL STORAGE AT T-PLANT (EIS0008A) 
WHC-SD-SNF-TI-002, Rev. 0

Figure 5-4. T Plant Pool.

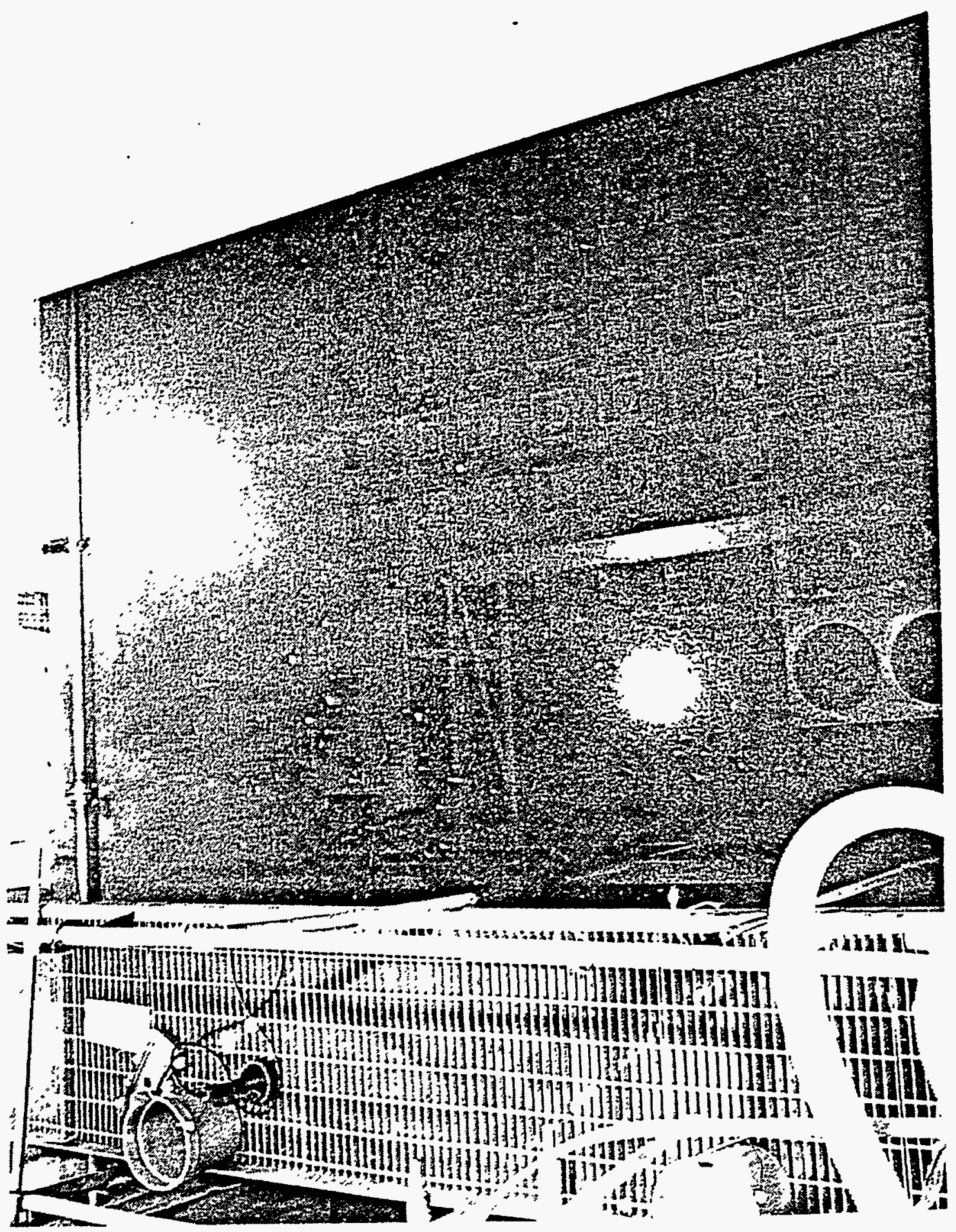


raw water was used for the initial pool fill. An installed demineralizer provides makeup water to replenish pool water lost by evaporation. An ion exchange column, installed in a radiation shield near the pool, is provided for removal of radioactive contamination from the pool water and for maintaining water quality.

Two pumps, each capable of providing a flow of $38 \mathrm{~L} / \mathrm{min}(10 \mathrm{gal} / \mathrm{min})$, are installed for recirculation of pool water through the ion exchange column and the water chillers. Two chillers, each capable of removing up to $133,000 \mathrm{~kJ} /$ hour of radioactive decay heat, are installed near the pool. One pump and one chiller will normally be on standby. Testing is currently underway at $T$ Plant to determine if the chillers are required (Lanning 1992). If testing shows that the chillers are not required, they will be removed from service.

The storage pool contains 72 irradiated fuel blanket assemblies from the Shippingport PWR Core II, stored vertically underwater in $2.4-\mathrm{m} \times 1.5-\mathrm{m}(8-\mathrm{ft} \times 5-\mathrm{ft})$ racks. Approximately 66 percent of the available pool floor space is currently being used. Each assembly is stored in a separate compartment of a rectangular metal rack. The fuel

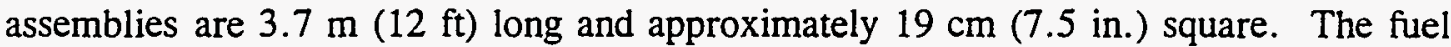
inventory has a total mass of 38.4 metric tons. The fuel consists of parallel plates of uranium oxide clad in Zircaloy-4.

The irradiated fuel has been at T Plant since 1978 and 1979, when it was shipped from the Shippingport PWR Core II to the Hanford Site. The initial plan was to store the fuel in the $\mathrm{T}$ Plant storage pool for up to 20 years.

\subsection{DRY STORAGE AT T PLANT}

An evaluation was made to determine the technical feasibility of removing the water from the storage pool and continuing to store the irradiated fuel in a dry condition using the existing racks (WHC 1994a). As of February 4, 1994, twenty years have passed since the irradiation of Shippingport PWR Core II fuel. Each assembly is calculated to generate less than $105 \mathrm{~W}$ of thermal energy. It has been calculated that an air flow of $2,800 \mathrm{~L} / \mathrm{min}$ (100 stdft $3 / \mathrm{min}$ ) past the fuel would be sufficient to keep the fuel temperature low enough for minimal fuel cladding degradation. Storing the fuel dry would eliminate the need for chiller maintenance and replacement, continued water quality surveillance and maintenance, and concerns over the integrity of the pool.

In addition to providing thermal cooling to the fuel, the pool water also provides radiation shielding to workers. In order to store the fuel dry, concrete cover blocks like those on other cells would need to be placed over the pool to replace the shielding previously provided by the water. A ventilation system, capable of supplying $2,800 \mathrm{~L} / \mathrm{min}$ (100 $\left.\mathrm{stdft}^{3} / \mathrm{min}\right)$ air flow, would be required to cool the fuel. 


\section{WHC-SD-SNF-TI-002, Rev. 0}

\subsection{TRANSPORTATION}

Access to the pool cell is via the railroad tunnel. Highway access is also available to T Plant. A method for retrieving the fuel from the basin and placement for transport would need to be developed before either rail or highway transport.

\subsection{ESTIMATED STAFF SIZE-AND OPERATIONAL COST}

\subsubsection{Estimated Staff Size}

T Plant currently has 204 full time staff to support the decontamination and irradiated fuel storage activities. Of this total number, 165 are located at T Plant including 29 nuclear process operators; 20 Health Physics technicians; 28 systems, cognizant, or upgrade engineers; 8 environmental engineers; 23 crafts workers; 9 plant engineers; 13 work control (planner/scheduler); 8 administration; 17 managers; and 10 secretaries/clerks. The remaining 39 personnel are not located at T Plant and include Training, Programs, Laboratories, engineering (Technical Assistance), Site Services, and Restoration and Remediation personnel.

Approximately 2.5 full time staff work directly in fuel storage ${ }^{1}$; however, many more indirectly support fuel storage while they are directly supporting the other $\mathrm{T}$ Plant activities.

\subsubsection{Estimated Operational Cost}

The total operating budget for $\mathrm{T}$ Plant is approximately $\$ 31$ million per year. Only a small fraction (approximately $\$ 185$ thousand per year) is exclusively used for maintenance and surveillance of existing fuel pool storage systems.

\subsection{ESTIMATED OPERATIONAL DOSE COMMITMENT}

The estimated operational dose to workers associated with the storage of the Shippingport PWR Core II fuel at T Plant is 0.5 man-rem per year. This dose is incurred during surveillance activities, pool system maintenance, water quality sampling, and pool cleaning operations.

'Information obtained from T Plant Work Control. 
WHC-SD-SNF-TI-002, Rev. 0

\subsection{ESTIMATED ROUTINE ENVIRONMENTAL RELEASES} follows:

The estimated environmental releases have been divided into four categories as

- Radiological airborne emissions

- Nonradiological airborne emissions

- Radiological liquid effluents

- Nonradiological liquid effluents.

\subsubsection{Radiological Airborne Emissions}

Environmental releases from the operation of T Plant for calendar years 1990, 1991, and 1992, are presented in Table 5-1. Radionuclide air emissions are from the 291-T-1 stack. This stack exhausts filtered air from the 221-T Canyon Building, including the irradiated fuel storage pool cell and process ventilation. Emission monitoring consists of a record sampler and a beta-gamma continuous air monitor.

Table 5-1. Radiological Airborne Emissions at T Plant.

\begin{tabular}{|l|c|c|c|}
\hline \multicolumn{1}{|c|}{ Radionuclide } & $\begin{array}{c}1992 \text { totals (Ci) } \\
\text { (DOE-RL 1993b) }\end{array}$ & $\begin{array}{c}1991 \text { totals (Ci) } \\
\text { (DOE-RL 1992) }\end{array}$ & $\begin{array}{c}1990 \text { totals (Ci) } \\
\text { (DOE-RL 1991) }\end{array}$ \\
\hline${ }^{90} \mathrm{Sr}$ & $1.2 \mathrm{E}-05 \mathrm{Ci}$ & Not available & Not available \\
\hline${ }^{137} \mathrm{Cs}$ & $1.3 \mathrm{E}-05 \mathrm{Ci}$ & Not available & Not available \\
\hline${ }^{239.240} \mathrm{Pu}$ & $2.2 \mathrm{E}-05 \mathrm{Ci}$ & $1.3 \mathrm{E}-04 \mathrm{Ci}$ & $3.3 \mathrm{E}-05 \mathrm{Ci}$ \\
\hline${ }^{241} \mathrm{Am}$ & $2.0 \mathrm{E}-06 \mathrm{Ci}$ & $1.3 \mathrm{E}-05 \mathrm{Ci}$ & $3.6 \mathrm{E}-06 \mathrm{Ci}$ \\
\hline Total beta & Not available & $9.3 \mathrm{E}-04 \mathrm{Ci}$ & $1.0 \mathrm{E}-04 \mathrm{Ci}$ \\
\hline Total flow & $4.6 \mathrm{E}+08 \mathrm{~m}^{3}$ & $5.7 \mathrm{E}+08 \mathrm{~m}^{3}$ & $4.2 \mathrm{E}+08 \mathrm{~m}^{3}$ \\
\hline
\end{tabular}

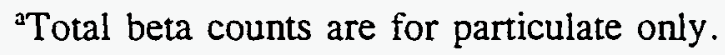

\subsubsection{Non-Radiological Airborne Emissions}

There is no routine monitoring of nonradioactive releases for $T$ Plant. Any routine releases which might occur have not been considered to be significant, and therefore no constituents are measured. 


\subsubsection{T Plant Stack Information \\ (DOE-RL 1993b and WHC 1993d)}

There are two release points from the facility: 291-T-1 and the 296-T-13. The 291-T-1 stack is the primary exhaust point. The 296-T-13 is used only when the 291-T-1 stack is down. For normal calculations, it is recommended that the 291-T-1 stack be used.

Flow rate: $291-\mathrm{T}-1-1,000,000 \mathrm{~L} / \mathrm{min}\left(36,000 \mathrm{ft}^{3} / \mathrm{min}\right)$ $296-\mathrm{T}-13-850,000 \mathrm{~L} / \mathrm{min}\left(30,000 \mathrm{ft}^{3} / \mathrm{min}\right)$

Stack height: $291-\mathrm{T}-1-61 \mathrm{~m}(200 \mathrm{ft})$ $296-\mathrm{T}-13-20.7 \mathrm{~m}(67.9 \mathrm{ft})^{1}$

Stack Diameter: $291-\mathrm{T}-1-1.5 \mathrm{~m}(5 \mathrm{ft})$ at top of stack 296-T-13 - Square duct $60 \mathrm{~cm} \times 60 \mathrm{~cm}(2 \mathrm{ft} \times 2 \mathrm{ft})$

Temperature: Dependent on environmental conditions, ranges are from approximately $10 \circ \mathrm{C}(50 \circ \mathrm{F})$ in the winter to $32 \circ \mathrm{C}(90 \circ \mathrm{F})$ in the summer.

Emission Control: High-efficiency particulate air (HEPA) filtration

\subsubsection{Radiological Liquid Effluents}

The only liquid discharge associated with irradiated fuel storage at T Plant is a 15- to 30- $\mathrm{L} / \mathrm{min}$ (4- to 8-gal/min) discharge of filtered Columbia River water (referred to as raw water) from the tertiary cooling water loop on the pool water chillers. If chiller-off test demonstrates that chillers are unnecessary, this discharge will be eliminated. The raw water is discharged to the soil via the T Plant wastewater stream to the 216-T-4-2 ditch. After June 1995, the T Plant wastewater stream will be discharged through the 200 Area treated effluent disposal facility and will meet the 200 Area treated effluent disposal facility acceptance criteria. The 200 Area treated effluent disposal facility discharge ponds will be located outside of the 200 East Area.

\subsubsection{Non-Radiological Liquid Effluents}

The information presented in Section 5.7.4 for radiological liquid effluents applies also to nonradiological liquid effluents.

\footnotetext{
'The height of release point at the actual stack is only about $5 \mathrm{~m}(16 \mathrm{ft})$; however, the stack is located on the roof of the 221-T Building.
} 


\subsection{BOUNDING ACCIDENT SCENARIOS AND RELATED ENVIRONMENTAL RELEASES (WHC 1993e, RHO 1978a, and RHO 1978b)}

\subsubsection{Airborne Radiological Releases}

The bounding credible accident for support of irradiated Shippingport PWR Core II fuel storage at $\mathrm{T}$ Plant is a damaged fuel assembly. This scenario was developed for the transport of the fuel into $T$ Plant. In the accident scenario, a fuel assembly is dropped, either into the storage pool or on the canyon deck, and the impact fractures 600 fuel wafers (approximately 3 percent of the assembly contents). All of the volatile ${ }^{85} \mathrm{Kr}$ from the damaged wafers is assumed to escape and a small fraction of the nonvolatile radionuclides from the broken wafers are assumed to be released to the canyon atmosphere as particulates. Most of the particulates released would be removed by the two stages of HEPA filtration, but all of the ${ }^{85} \mathrm{Kr}$ is released out the stack. Table 5-2 presents specific nuclides and activities that could be released from the stack. It is important to note that the information in Table 5-2 was developed in 1978 , and the amount of ${ }^{85} \mathrm{Kr}$ has decayed by a factor of approximately 2.8 .

\subsubsection{Non-Radiological Airborne Releases}

No accident scenarios were postulated for irradiated fuel storage at $\mathrm{T}$ Plant that involve the release of airborne nonradiological hazardous emissions.

\subsubsection{Radiological Liquid Releases}

The T Plant SAR (WHC 1993e) and the Safety Assessment Document - Shippingport PWR Core II (RHO 1978b) do not include postulated accidents involving storage pool failure or other radiological liquid releases. Liquids released from the storage pool in the case of an accident would most likely be contained within the T Plant building.

\subsubsection{Non-Radiological Liquid Releases}

The information presented in Section 5.8 .4 for radiological liquid releases applies also to nonradiological liquid releases. 
WHC-SD-SNF-TI-002, Rev. 0

Table 5-2. Accident Release Fractions for Damaged Module.

\begin{tabular}{|l|c|c|c|c|c|c|}
\hline Radionuclide & $\begin{array}{c}\text { Source } \\
\text { term } \\
(\mathrm{Ci})\end{array}$ & $\begin{array}{c}\text { Release } \\
\text { reactor } \\
(\mathrm{Ci})\end{array}$ & $\begin{array}{c}\text { Release } \\
\text { on deck } \\
(\mathrm{Ci})\end{array}$ & $\begin{array}{c}\text { Suspension } \\
\text { factor }\end{array}$ & $\begin{array}{c}\text { Airborne } \\
\text { release in } \\
\text { canyon (Ci) }\end{array}$ & $\begin{array}{c}\text { Stack } \\
\text { release } \\
(\mathrm{Ci})\end{array}$ \\
\hline${ }^{55} \mathrm{Fe}$ & 3 & 0.1 & 0.3 & $1 \times 10^{-3}$ & $3 \times 10^{-4}$ & $5 \times 10^{-6}$ \\
\hline${ }^{60} \mathrm{Co}$ & 2 & 0.1 & 0.2 & $1 \times 10^{-3}$ & $2 \times 10^{-4}$ & $3 \times 10^{-6}$ \\
\hline${ }^{85} \mathrm{Kr}$ & 9.6 & 1 & 9.6 & 1 & 9.6 & 9.6 \\
\hline${ }^{90} \mathrm{Sr}$ & 83 & 0.1 & 8.3 & $1 \times 10^{-3}$ & $8 \times 10^{-3}$ & $1 \times 10^{-4}$ \\
\hline${ }^{106} \mathrm{RuRh}$ & 70 & 0.1 & 7 & $1 \times 10^{-3}$ & $7 \times 10^{-3}$ & $1 \times 10^{-4}$ \\
\hline${ }^{125} \mathrm{Sb}$ & 2 & 0.1 & 0.2 & $1 \times 10^{-3}$ & $2 \times 10^{-4}$ & $3 \times 10^{-6}$ \\
\hline${ }^{134} \mathrm{Cs}$ & 6 & 0.1 & 0.6 & $1 \times 10^{-3}$ & $6 \times 10^{-4}$ & $8 \times 10^{-6}$ \\
\hline${ }^{137} \mathrm{Cs}$ & 100 & 0.1 & 10 & $1 \times 10^{-3}$ & $1 \times 10^{-2}$ & $1 \times 10^{-4}$ \\
\hline${ }^{137} \mathrm{Ba}$ & 90 & 0.1 & 9 & $1 \times 10^{-3}$ & $9 \times 10^{-3}$ & $1 \times 10^{-4}$ \\
\hline${ }^{144} \mathrm{CePr}$ & 70 & 0.1 & 7 & $1 \times 10^{-3}$ & $7 \times 10^{-3}$ & $1 \times 10^{-4}$ \\
\hline${ }^{147} \mathrm{Pm}$ & 110 & 0.1 & 11 & $1 \times 10^{-3}$ & $1 \times 10^{-2}$ & $1 \times 10^{-4}$ \\
\hline $\mathrm{Rare}$ earths & 18 & 0.1 & 1.8 & $1 \times 10^{-3}$ & $2 \times 10^{-3}$ & $3 \times 10^{-5}$ \\
\hline${ }^{239} \mathrm{Pu}$ & $12 \mathrm{~g}$ & 0.1 & $1.0 \mathrm{~g}$ & $1 \times 10^{-3}$ & $1 \times 10^{-3} \mathrm{~g}$ & $1 \times 10^{-5} \mathrm{~g}$ \\
\hline${ }^{240} \mathrm{Pu}$ & $5 \mathrm{~g}$ & 0.1 & $0.5 \mathrm{~g}$ & $1 \times 10^{-3}$ & $5 \times 10^{-4} \mathrm{~g}$ & $7 \times 10^{-6} \mathrm{~g}$ \\
\hline${ }^{241} \mathrm{Pu}$ & $2 \mathrm{~g}$ & 0.1 & $0.2 \mathrm{~g}$ & $1 \times 10^{-3}$ & $2 \times 10^{-4} \mathrm{~g}$ & $3 \times 10^{-6} \mathrm{~g}$ \\
\hline${ }^{242} \mathrm{Pu}$ & $0.7 \mathrm{~g}$ & 0.1 & $0.07 \mathrm{~g}$ & $1 \times 10^{-3}$ & $7 \times 10^{-5} \mathrm{~g}$ & $1 \times 10^{-6} \mathrm{~g}$ \\
\hline
\end{tabular}


WHC-SD-SNF-TI-002, Rev. 0

This page intentionally left blank. 


\subsection{BUILDING}

\subsection{GENERAL INFORMATION}

The 324 Building Waste Technology Engineering Laboratory was initially completed in 1965 in the 300 Area of the Hanford Site. The Building contains facilities for conducting diverse studies on the chemical and physical processing of high-level radioactive materials, physical and chemical characteristics of irradiated materials, and nonradioactive process development. The facility is operated by Pacific Northwest Laboratory (PNL) for the DOE. The 324 Building facilities and fuel storage are shown schematically in Figures 6-1 through 6-4.

The 324 Building contains laboratories, hot cells, support facilities, and offices (275 occupants in 110 offices) to pursue technical studies that range from laboratory to pilotplant scale. These studies involve the use of materials having levels of radioactivity from natural background to megacuries. In addition, laboratory research is performed to develop basic and applied data in support of DOE. The facility has been continually maintained and major additions were made in 1979, 1980, and 1989. The major additions are not used for work with nuclear materials.

The 324 Building is $62.5 \mathrm{~m}(205 \mathrm{ft}) \times 71.6 \mathrm{~m}(235 \mathrm{ft})$ in plan and $13.7 \mathrm{~m} \mathrm{(45} \mathrm{ft)} \mathrm{in}$ height above ground level. The 324 Building has a partial basement, first, second, and partial third floors for a total of approximately $9,450 \mathrm{~m}^{2}\left(102,000 \mathrm{ft}^{2}\right)$ of floor area.

The 324 Building is a metal-frame structure erected on reinforced-concrete footings, basement walls, and floor slabs. The above-ground exterior shell is constructed of fluted steel panels, except for two portions that are concrete block masonry. The roof has a steel deck covered by insulated concrete and built-up tar and gravel. In addition to office space, the building contains two groups of heavily shielded hot cells, their operating and service galleries, and two vaults for storing liquid radioactive materials. The building also houses two engineering development laboratories and a high bay area used for nonradioactive process development activities. The basement contains laboratories and a fissionable materials storage vault. Design features offer protection against fires, criticalities, and other potential hazards. In general, several successive barriers to the release of radioactive or toxic materials are employed, with the exterior metal and masonry walls constituting a final barrier before release to the environment.

The two groups of hot cells are the shielded materials facility and the radiochemical engineering cells. Both groups of hot cells in the 324 Building are equipped with cranes, remote manipulators, viewing windows, various test equipment, process offgas systems, and 


\section{WHC-SD-SNF-TI-002, Rev. 0}

Figure 6-1. 324 Building Hot Cell Areas Floor Plan.

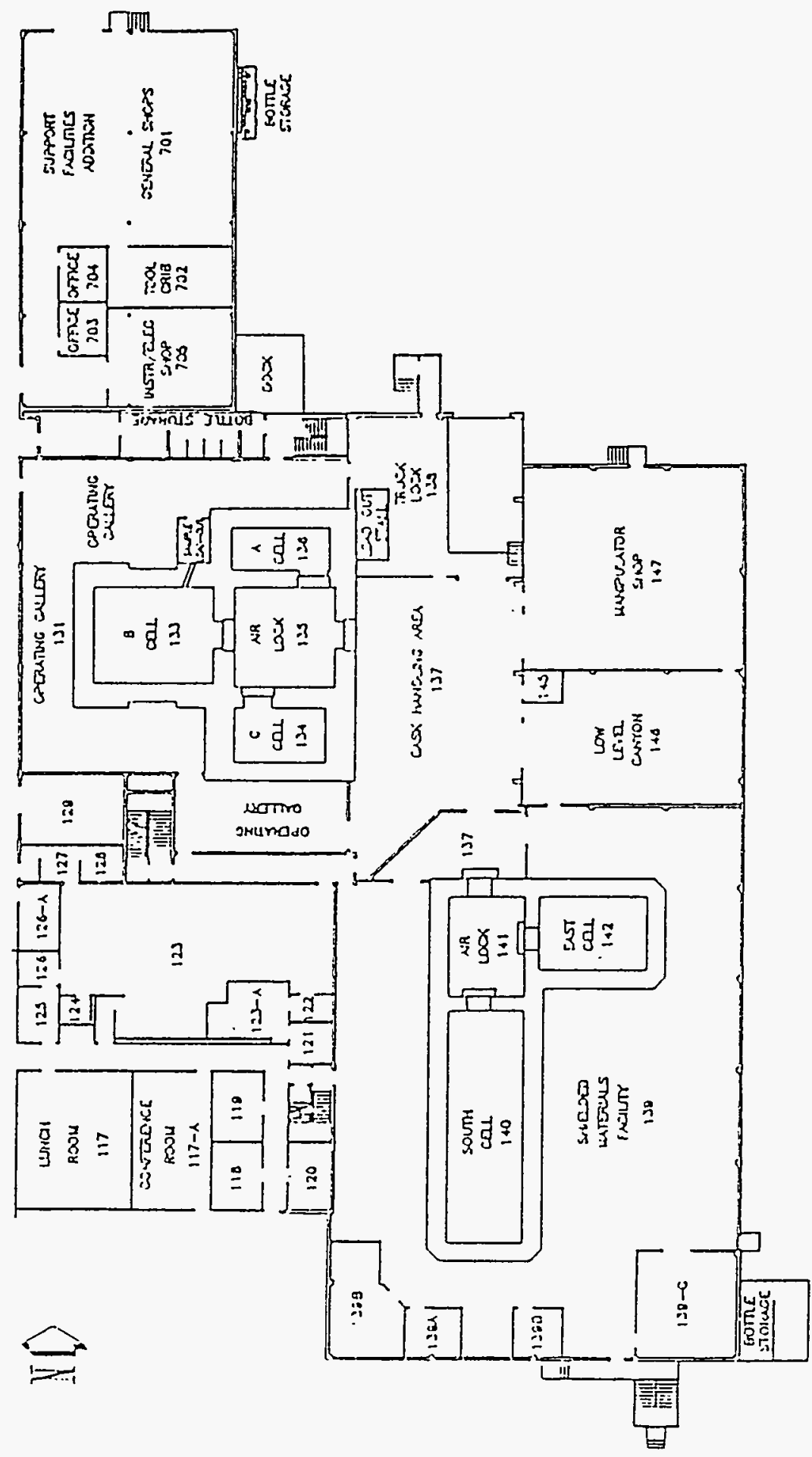


Figure 6-2. Radiochemical Engineering Cells (324 Building).

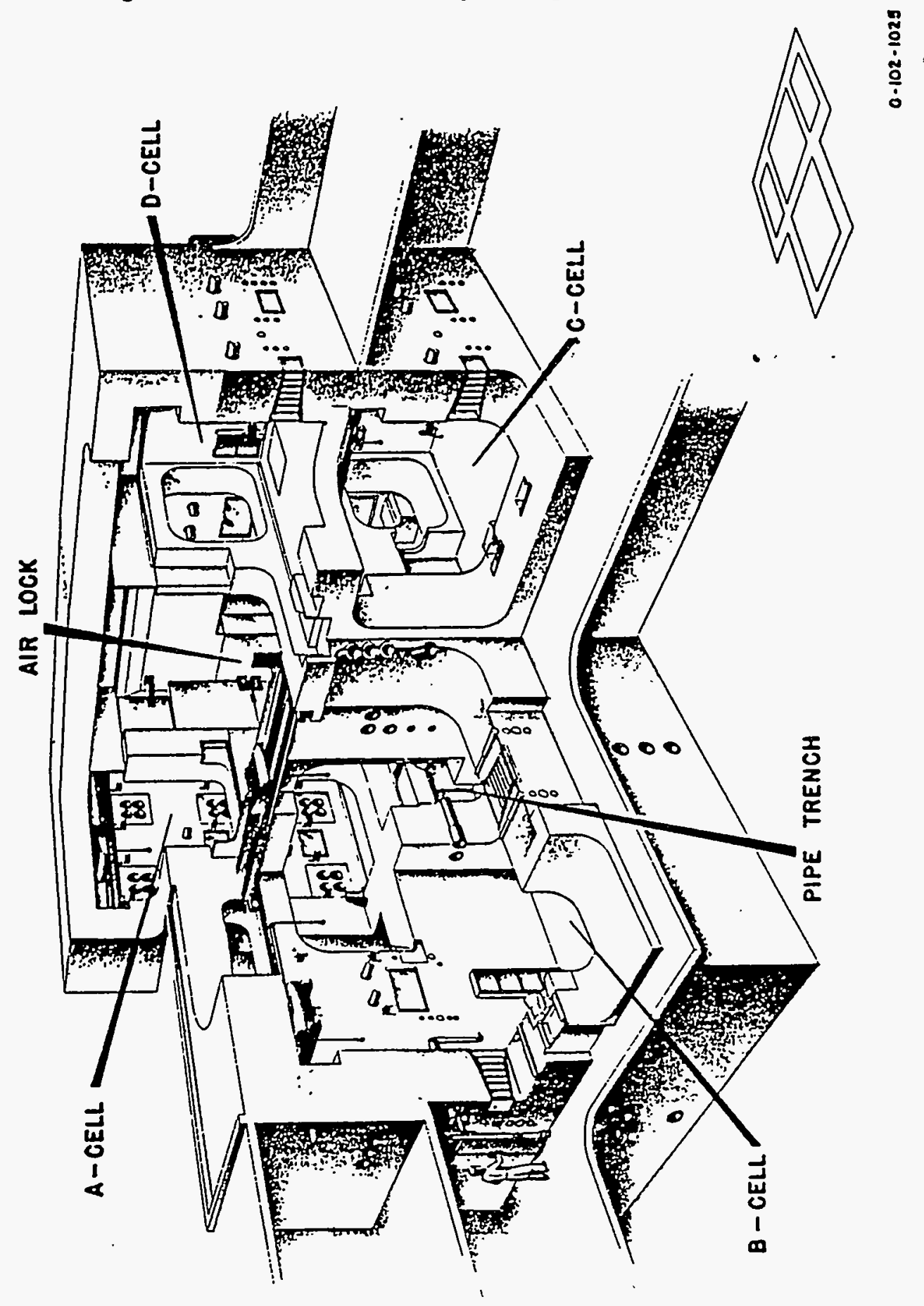


WHC-SD-SNF-TI-002, Rev. 0

Figure 6-3. Shielded Materials Facility Cells (324 Building).

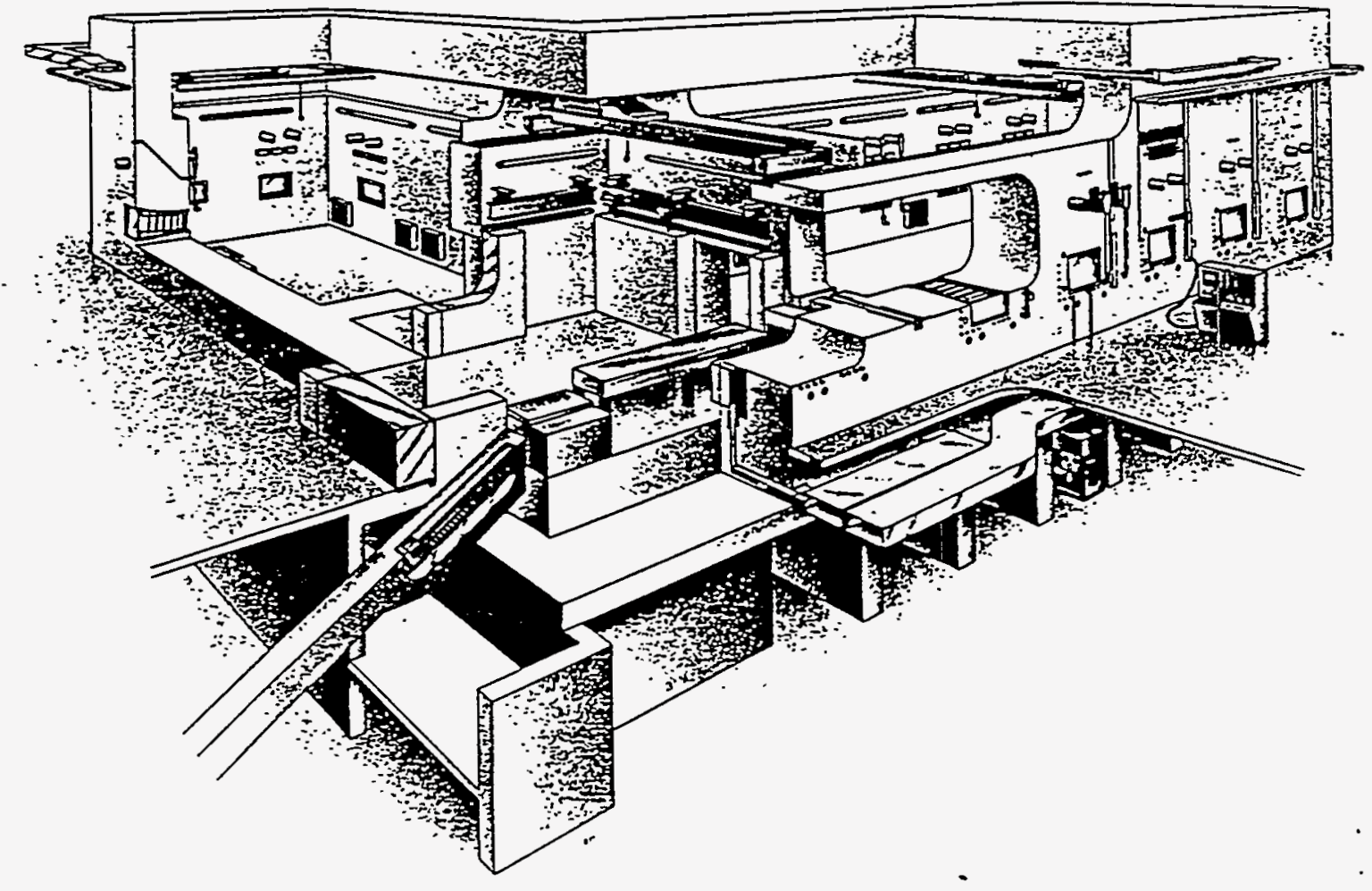


Figure 6-4. Fuel Storage in B Cell (324 Building).

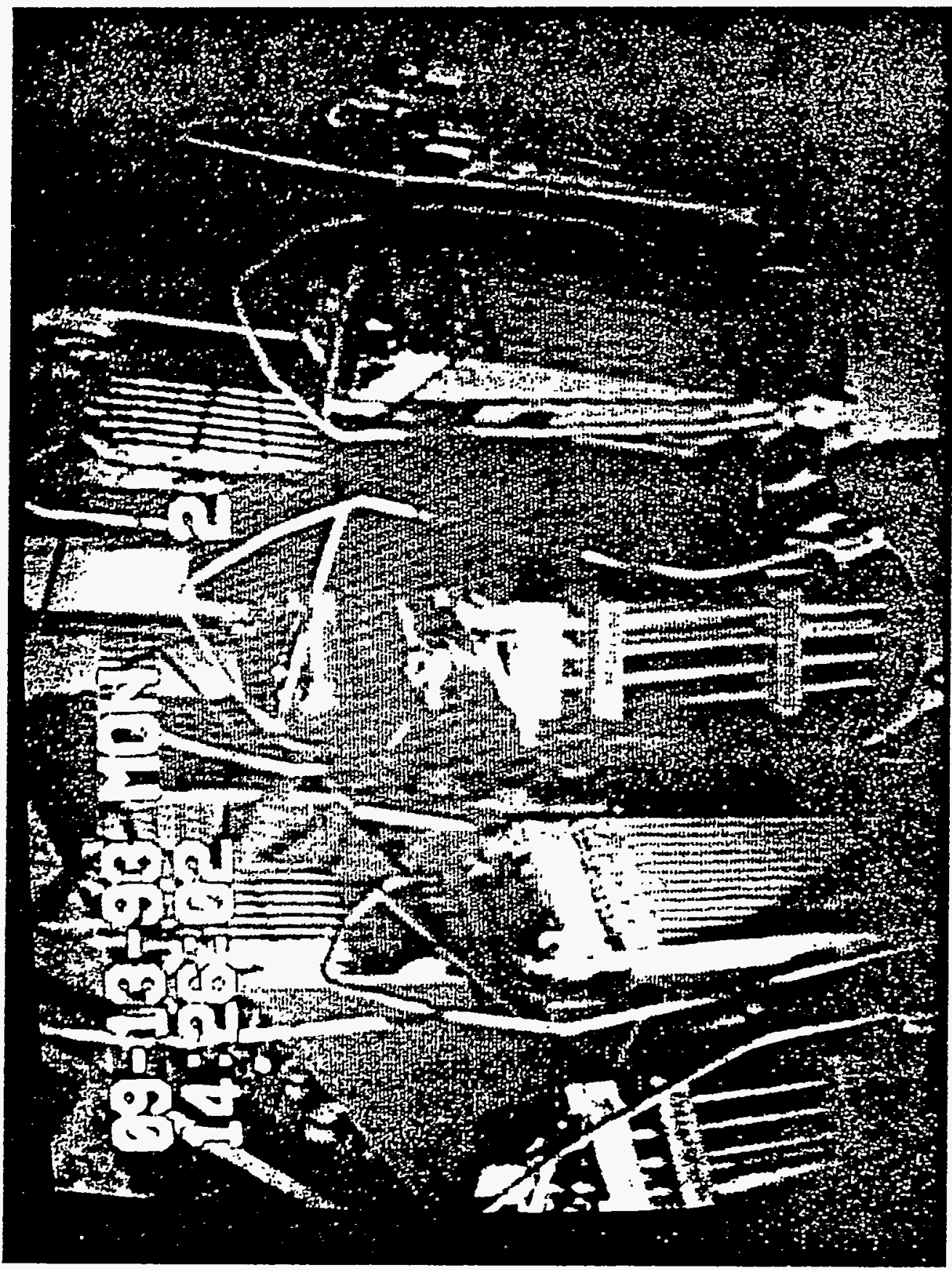


WHC-SD-SNF-TI-002, Rev. 0

various services including air, water, and electrical. The cells and vaults are designed to shield the workers from direct radiation and, with the ventilation system and its HEPA filters, to confine any radioactive particulate materials. The irradiated fuel stored at the 324 Building is located in cells B and D of the radiochemical engineering cells. A truck lock and cask handling area is located due east of the radiochemical engineering cells. A steel partition separates the truck lock from the cask handling area. All shipping of casks is done through these two areas.

\subsection{IRRADIATED FUEL STORAGE IN THE 324 BUILDING}

Irradiated reactor fuel storage in the 324 Building continues only because no location has been established to accept the fuel. The fuel does not support any current mission in the 324 Building.

The radiochemical engineering cells are located in the north portion of the 324 Building. The cell complex consists of an airlock cell, and A, B, C, and D cells. The airlock cell and $A, B, C$, and $D$ cells are joined forming a " $T$ " and are surrounded by an operating gallery. Cell shielding is constructed of normal- and high-density magnetite concrete. The airlock cell, B cell, and C cell have stainless steel floors and walls. A cell and $\mathrm{D}$ cell have stainless steel floors and mild steel walls with corrosion-resistant coatings.

The radiochemical engineering cells are used primarily for engineering development work with high levels of radioactivity. All normal operations in the cell complex are done remotely. Only in cases of major program changes or severe maintenance problems (and after cell decontamination) might personnel access to the cells through the airlock cell be considered.

Several major high-level radioactive test programs have been conducted in the radiochemical engineering cells since 1966: the Waste Solidification Engineering Prototypes from 1966 through 1972, the Nuclear Waste Vitrification Project from 1977 through 1979 , the Pilot-Scale Radioactive Liquid-Fed Ceramic Melter project from 1982 through 1987, and the Federal Republic of Germany Canister Fabrication project from 1988 through 1989.

Cleanout of all four hot cells was initiated in 1988 and is scheduled to be completed in fiscal year 2000 as part of the 324 Building and 325 Building hot cell cleanout program. Future work may involve vitrification of radioactive and hazardous materials, chemical and radiochemical process separations and process development, and work with fuels, defense component targets, and waste materials.

\subsubsection{Airlock Cell}

The airlock cell is used primarily as a transition zone for maintenance, decontamination, and transfer of materials and equipment into and out of the adjoining $A, B$, $C$, and $D$ cells. The airlock cell interior dimensions are approximately $6.7 \mathrm{~m}$ wide $\times 6.5 \mathrm{~m}$ 
long $\times 10.4 \mathrm{~m}$ high (22 ft $\times 21.5 \mathrm{ft} \times 34 \mathrm{ft})$. It is equipped with a $680-\mathrm{kg}(1,500-\mathrm{lb})$ remotely operated jib crane with a television camera mounted on the end of the boom, two master slave manipulator stations, one lead-glass and oil-filled viewing window in the wall, and one lead-glass and oil-filled viewing window in the door. The room is served by a 4,536-kg (5-ton) remotely operated bridge crane that also serves A and D cells. Below the A and D cell crane rails are crane rails that allow the B cell crane to enter the airlock cell.

Hinged shielded doors, operated by air cylinders, provide access for transfer of material, equipment, and cranes into and out of the airlock cell from A, B, C, and D cells. A material and equipment transfer system, consisting of a pneumatic tugger, dollies, and tracks is used for transferring large items between the airlock cell and the cask handling area.

The airlock cell also includes a pipe trench in the cell floor (covered by concrete blocks) and diagonal piping sleeves into the cells where semi-remote connections are made between hot-process lines from equipment in the cells and connections to the tank vaults (high- and low-level vaults).

\subsubsection{B Cell}

B cell is $6.7 \mathrm{~m}$ wide $\times 7.6 \mathrm{~m}$ long $\times 9.3 \mathrm{~m}$ high $(22 \mathrm{ft} \times 25 \mathrm{ft} \times 30.5 \mathrm{ft})$. The cell is

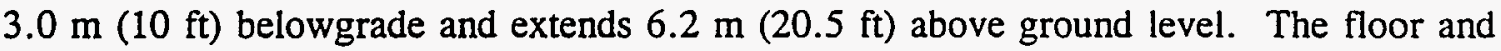

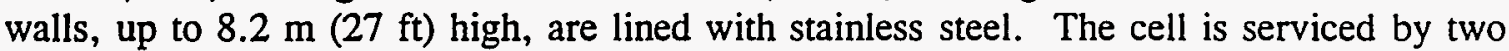
remotely operated cranes with capacities of 2,722 and $5,443 \mathrm{~kg}$ ( 3 and 6 tons), respectively. These cranes travel through a 5.2-m- (17-ft-) high doorway into the neighboring airlock cell. The cell is surrounded on three sides by operating galleries on the first and second floors and on two sides by a gallery at the basement level.

Shielding walls at the three operating faces of the first-floor operating gallery level are $1.2-\mathrm{m}$ - (4-ft-) thick, high-density concrete. Each of these walls has a large viewing -window, two master slave manipulators, and a number of sleeved holes for supplying services to the cell. The remaining cell-to-gallery shielding walls are $1.4-\mathrm{m}-(4.5-\mathrm{ft}-)$ and $1.2-\mathrm{m}-(4-\mathrm{ft}-)$ thick normal concrete at the first and second floors and basement, respectively. B cell "plug-in" modular groupings of process equipment are attached to the shielding walls with rack-mounted shield plugs containing process piping and wiring. Connections are made by contact maintenance on the "cold" side of the shielding walls. The walls contain 30.5-cm- (12-in.-) diameter sleeves through which major process services are run. The sleeves, terminating in the galleries and above the main floor level in the airlock, are for "cold" connections (i.e., steam, water, air, and electrical supplies) except for some heatexchanger steam condensate and cooling-water effluents that could become contaminated.

A fuel assembly storage rack that can hold nine spent fuel assemblies in a geometrically safe configuration for criticality is located in the northeast corner of B cell. All nine positions are currently filled by either fuel assemblies or nonfuel-bearing hardware. 
There are two cubicles on the west wall of B cell. The cubicles consist of steel castings $46 \mathrm{~cm}$ (18 in.) thick $\times 137 \mathrm{~cm}$ (54 in.) square, set flush with the inside wall of the cell to create a $91-\mathrm{cm}-(3-\mathrm{ft}-)$ deep cavity in the cell wall. Equipment inserted through the cubicle openings can be connected to required services without entering the cell, and the connections can be maintained by personnel without significant radiation exposure. The cubicles are sealed by 10.2 -cm- (4-in.-) thick, hinged steel doors on the operating gallery side. Service piping, including radioactive offgas and sewer connections and nonradioactive utility lines (air, water, and steam) extend into each cubicle. From the cell side, each cubicle casting is penetrated by four $22.9-\mathrm{cm}$ - (9-in.-) inside-diameter cylindrical openings.

A sample room is located in the corner formed between $A$ cell and $B$ cell. The room is $2.1 \mathrm{~m}$ wide $\times 3 \mathrm{~m}$ long $\times 3.4 \mathrm{~m}$ high $(7 \mathrm{ft} \times 10 \mathrm{ft} \times 11 \mathrm{ft}$ ). The room encloses the operating gallery side of the sample transfer mechanism. The transfer mechanism is used to transfer small items into or out of B cell through 61-cm (24-in.) access doors.

In 1986, During melter development work, approximately $1,000,000 \mathrm{Ci}$ of ${ }^{137} \mathrm{Cs}$ and $500,000 \mathrm{Ci}$ of ${ }^{90} \mathrm{Sr}$ were spilled to the floor of $\mathrm{B}$ cell. The spilled material was a nitrate solution. It was expected that the spilled liquid would drain to the cell sump; however, the floor of the cell was covered with a layer of dust. The spilled material is assumed to have been absorbed by the dust and, after liquid evaporation, remains held up on the cell floor in a potentially dispersible form. It is further assumed that the cesium and strontium holdup is powder mixed with dust. The holdup material is the single largest inventory of radionuclides in $\mathrm{B}$ cell.

B cell is nearly filled with equipment including tanks, glass melters, and other various miscellaneous process equipment from past and ongoing development activities. The total inventory of radionuclides in B cell (as of November 29, 1990) is approximately $1,900,000 \mathrm{Ci}$. This figure includes approximately $380,000 \mathrm{Ci}$ of mixed fission products in the stored fuel assemblies (PNL 1992b). The cell is currently being cleaned to remove the holdup from the floor and equipment that is currently unneeded. The cleanup is scheduled to be completed in 1997.

\subsubsection{Cell}

$\mathrm{D}$ cell is $4.0 \mathrm{~m}$ wide $\times 6.4 \mathrm{~m}$ long $\times 5.2 \mathrm{~m}$ high $(13 \mathrm{ft} \times 21 \mathrm{ft} \times 17 \mathrm{ft}$ ) and is located

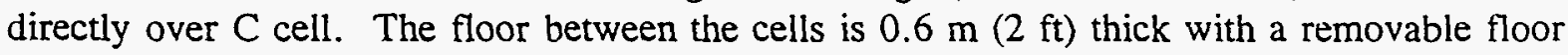
plug. The short east and west walls are $1.7-\mathrm{m}-(5.5-\mathrm{ft}-)$ thick normal concrete and border on the cask handling area and operating gallery, respectively. The long north wall is $1.1-\mathrm{m}-$ (3.5-ft-) thick normal concrete and borders the airlock cell. The long south wall is $1.2-\mathrm{m}-$ (4-ft-) thick high-density concrete and borders the operating gallery. 
D cell is similar to the other radiochemical engineering cells and has two shielding windows, two pairs of master slave manipulators, a remote viewing periscope, and closedcircuit television. The floor is lined with stainless steel; the walls are lined with mild steel with a corrosion-resistant coating.

D cell access is via the airlock cell or through a small transfer port communicating with a glovebox. This glovebox is used for experiments using microcuries of radioactive materials in encapsulated form and connects to the ventilation system. A small 10-cm (4-in.) pass-through port is available for one-way movement of materials into the cell.

D cell is serviced by the airlock cell crane as described in Section 6.2.1.

All normal operations in D cell are done remotely; all services and facilities are provided at the front face and connected through shielding plugs or offset piping.

D cell contains spent fuel as both complete pins and rods, and as cut pieces of pins and rods. The total inventory of radionuclides in D cell is approximately $642,000 \mathrm{Ci}$. Of this total inventory, approximately $33,000 \mathrm{Ci}$ is mixed fission products in the spent fuel. The remaining inventory of radionuclides in $\mathrm{D}$ cell is cesium capsules or borosilicate glass encapsulated mixed fission products.

\subsection{TRANSPORTATION}

Although there are rail spurs in the 300 Area, no direct rail access to the 324 facility is available. Any movement of materials to or from the facility would need to be done by truck. The facility has an overhead crane with a capacity of 27 metric tons (30 tons), which could be used to move the fuel inside the building. There are also some restrictions to movement of heavy or large objects within the facility; specifically, the floor loading capacity is limited to $978 \mathrm{~kg} / \mathrm{m}^{2}\left(200 \mathrm{lb} / \mathrm{ft}^{2}\right)$. The hot cell airlock height is also somewhat limited.

\subsection{ESTIMATED STAFF SIZE AND OPERATIONAL COST}

\subsubsection{Estimated Staff Size}

The 324 Building has approximately 275 occupants including scientists, technicians, managers, administrative professionals, operators, and craftspersons. There are no daily activities involving irradiated fuel. The fuel is inventoried semi-annually, and remains undisturbed in storage the remainder of the time. Less than one full time employee is required for direct support to fuel storage activities in the building. 


\subsubsection{Estimated Operational Cost ${ }^{1}$}

Total costs for operation and maintenance of the 324 Building are highly dependent on nonfuel storage program activities within the facility, and can change greatly from year to year. A rough estimate of the total operating and maintenance costs can be calculated by multiplying the number of occupants in the building by the estimated average cost per employee per year. The average cost per PNL employee is $\$ 150,000 /$ year (including salary, administration, and utility costs); thus, the estimated annual operation and maintenance cost for the 324 Building is estimated at $\$ 40$ million.

Surveillance and maintenance costs for the 324 Building hot cells are approximately $\$ 2.7$ million per year (1994 dollars). The actual fuel storage cost is estimated at less than $\$ 100,000$ per year. Most of the irradiated fuel currently in storage at the 324 Building is located in B cell. The current annual budget for B cell cleanout is $\$ 9.4$ million.

\subsection{ESTIMATED OPERATIONAL DOSE COMMITMENT} (PNL 1993a)

Dose information for the 324 Building is included in the overall dose measurements for all Hanford Site PNL facilities and is not tabulated separately. The dose rate for all Hanford Site PNL facilities includes the dose rate for the 324, 325 and 327 Buildings, among others and is only given as a total. Since the majority of PNL work with highly radioactive materials at the Hanford Site is performed in the 324, 325, and 327 Buildings, most of the dose rate occurs in these three facilities. The totals for PNL facilities are as follows: 68 man-rem in 1990; 52 man-rem in 1991, and 58 man-rem in 1992. The total dose rate in 1992 was shared among 693 workers as follows: 552 workers received from 1 to 99 mrem, 64 workers received from 100 to $250 \mathrm{mrem}, 43$ workers received from 250 to $500 \mathrm{mrem}$, 20 workers received from 500 to $750 \mathrm{mrem}, 8$ workers received from 750 to $1,000 \mathrm{mrem}$, and 6 workers received from 1,000 to $2,000 \mathrm{mrem}$.

Spent fuel storage in the 324,325 , and 327 Buildings is in hot cells, casks, or pools, which effectively limit worker exposure. The dose rate to workers resulting from spent fuel storage is only a small fraction of the total. In B cell, for example, spent fuel accounts for only about 10 percent of the total radionuclide inventory in the cell. Further, B cell only accounts for a fraction of the total dose received in the facility since the cell has 1.2- to $1.4-\mathrm{m}-(4-$ to $4.5-\mathrm{ft}-)$ thick shielding walls to reduce worker dose to under $1 \mathrm{mrem} / \mathrm{hr}$.

\footnotetext{
'Information obtained from the 324 Building B Cell Cleanout Project Manager.
} 


\subsection{ESTIMATED ROUTINE ENVIRONMENTAL RELEASES}

(DOE-RL 1993b and WHC 1993d)

The estimated environmental releases have been divided into four categories as follows:

- Radiological airborne emissions

- Nonradiological airborne emissions

- Radiological liquid effluents

- Nonradiological liquid effluents.

\subsubsection{Radiological Airborne Emissions}

Airborne radiological releases from the all activities and operations in the 324 Building for calendar years 1990, 1991, and 1992, are presented in Table 6-1. Releases from the facility only associated with irradiated fuel storage are not available. Radionuclide air emissions from EP-324-01-S follow. This stack exhausts filtered building air. The exhaust is sampled for particulate alpha and beta radioactivity, ${ }^{131} \mathrm{I}$, and tritium. At present, no source of ${ }^{131} \mathrm{I}$ exists in the building.

Table 6-1. Radionuclide Releases from 324 Building.

\begin{tabular}{|c|c|c|c|}
\hline Radionuclide & $\begin{array}{c}1992 \text { totals }(\mathrm{Ci}) \\
\text { (DOE-RL 1993b) }\end{array}$ & $\begin{array}{c}1991 \text { totals }(\mathrm{Ci}) \\
\text { (DOE-RL 1992) }\end{array}$ & $\begin{array}{c}1990 \text { totals (Ci) } \\
\text { (DOE-RL 1991) }\end{array}$ \\
\hline${ }^{3} \mathrm{H}\left(\right.$ as $\left.\mathrm{H}_{2} \mathrm{O}\right)$ & $9.6 \mathrm{E}+00$ & $4.1 \mathrm{E}-01$ & Not available \\
\hline${ }^{3} \mathrm{H}\left(\mathrm{as} \mathrm{H}_{2}\right)$ & $2.2 \mathrm{E}+00$ & $5.6 \mathrm{E}-01$ & Not available \\
\hline Total alpha $^{\mathrm{a}}$ & $3.9 \mathrm{E}-07$ & $1.2 \mathrm{E}-06$ & $6.9 \mathrm{E}-07$ \\
\hline Total beta $^{2}$ & $6.4 \mathrm{E}-07$ & $6.1 \mathrm{E}-05$ & $3.1 \mathrm{E}-05$ \\
\hline Total flow & $1.4 \mathrm{E}+09 \mathrm{~m}^{3}$ & $1.3 \mathrm{E}+09 \mathrm{~m}^{3}$ & Not available \\
\hline
\end{tabular}

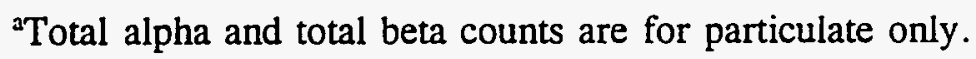

\subsubsection{Non-Radiological Airborne Emissions}

According to the, Safety Analysis Report for the 324 Building Waste Technology, Engineering Laboratory, nitrogen oxides $\left(\mathrm{NO}_{\mathrm{x}}\right)$ are released from the building to the atmosphere (PNL 1992b). However these $\mathrm{NO}_{\mathrm{x}}$ releases are not as a result of irradiated fuel storage. The measured $\mathrm{NO}_{x}$ stack concentrations are much below capacity limits regulated by the Tri-County Air Pollution Control Board. 
WHC-SD-SNF-TI-002, Rev. 0

\subsubsection{Building Stack Information}

(DOE-RL 1993b and PNL 1992b)

Stack Height: $48.4 \mathrm{~m}(160 \mathrm{ft})$

Flow rate: $2.5 \times 10^{6}$ to $2.8 \times 10^{6} \mathrm{~L} / \mathrm{min}\left(90,000\right.$ to $\left.100,000 \mathrm{ft}^{3} / \mathrm{min}\right)$

Diameter: $2.4 \mathrm{~m}(8 \mathrm{ft})$

Temperature: 13 to $24 \circ \mathrm{C}(55$ to $75 \circ \mathrm{F})$

\subsubsection{Radiological Liquid Effluents}

There are no routine liquid effluent streams resulting from irradiated fuel storage at the 324 Building.

\subsubsection{Non-Radiological Liquid Effluents}

There are no routine liquid effluent streams resulting from irradiated fuel storage at the 324 Building.

\subsection{BOUNDING ACCIDENT SCENARIO AND RELATED ENVIRONMENTAL RELEASES ${ }^{1}$}

\subsubsection{Airborne Radiological Releases}

The bounding accidental release of radioactivity results from a seismic event with process upsets. The seismic event analyzed for the 324 Building has a horizontal acceleration of $0.1 \mathrm{G}$ and a return period of 2,500 years. The seismic event damages the ventilation system and some of the external walls, providing a direct discharge route to the environment. The seismic event causes several significant process upsets. Three different process upsets were evaluated including (1) shielded materiais facility pin breach, (2) radiochemical engineering cell pin breach, and (3) high-level vault storage tank explosion. Additionally, highly mobile holdup material in B cell is released. Of the three process upsets only the radiochemical engineering cell pin breach is related to irradiated fuel storage in the facility. The impact from each of these four events is mitigated by emergency response actions.

\footnotetext{
'Information provided by 324 Building Safety Analysis.
} 
Of the three process upsets, the high-level vault storage tank explosion has the largest potential release. Solutions of ${ }^{137} \mathrm{Cs}$ and ${ }^{90} \mathrm{Sr}$ nitrate are stored in tanks in the high-level vault. Radiolytic effects from the decay of these cesium and strontium nitrate solutions produce hydrogen gas. Air sparging in the tanks removes the hydrogen and avoids buildup of potentially explosive concentrations of hydrogen. In the seismic event, it is postulated that sparge air is lost, hydrogen builds up to an explosive concentration, and the tank explodes releasing $390 \mathrm{Ci}$ of cesium and strontium to the environment.

The shielded material facility cell pin breach is the next most significant release. Cesium chloride powder is stored in pins in the shielded material facility cell. The process upset involves a spill of $800 \mathrm{~g}$ of the highly dispersible powder to the cell during a seismic event.

It is estimated that the floor of $\mathrm{B}$ cell in the 324 Building contains approximately $1,000,000 \mathrm{Ci}$ of ${ }^{137} \mathrm{Cs}$ and $500,000 \mathrm{Ci}$ of ${ }^{90} \mathrm{Sr}$ from past operational spills in $\mathrm{B}$ cell. The present form of the radioactive holdup is assumed to be a fine powder mixed with dust. (This is thought to be a conservative assumption because Facility Operations is having difficulty scraping the material off the floor.) The failure of the 324 Building exhaust ventilation system and wall damage in a $0.1 \mathrm{G}$ seismic event, along with shaking of the of the highly mobile holdup material, is postulated to cause a release of $100 \mathrm{Ci}$ of ${ }^{137} \mathrm{Cs}$ and $50 \mathrm{Ci}$ of ${ }^{9)} \mathrm{Sr}$ to the environment as nitrate salts mixed with dust.

Irradiated fuel is stored in B and D cells in the 324 Building. During a seismic event and remote handling of a fuel pin, the pin is assumed to be dropped and breached, releasing a fraction of the fission product gases from within the pin into the atmosphere of one of the cells. Although the release related to a pin breach in the radiochemical engineering cell during a seismic event is only a small fraction of the total release during the seismic event, this complete scenario is the worst-case accident scenario evaluated, associated with irradiated fuel storage. Cleanup activities are ongoing which will mitigate the accident scenario.

\subsubsection{Non-Radiological Airborne Releases}

A fire or explosion in a laboratory in which toxic chemicals are used could result in a release of a fraction of the chemicals. In this scenario, the assumption is made that some acetone spills onto a hot plate in a hood, flash vaporizes, and explodes. Three bottles of toxic chemicals are also assumed to be in the hood and impacted by the blast. The explosion leads to a fire that ignites combustibles in the hood and causes some of the toxic material spilled by the blast to become airborne.

The hood is assumed to contain a hot plate; $100 \mathrm{ml}(0.3 \mathrm{gal})$ of acetone in an open beaker; $900 \mathrm{ml}$ ( $2.7 \mathrm{gal})$ of acetone in a bottle; one-pound bottle each of hydrofluoric acid, arsenic trioxide, and nickel; and a small amount $(3.8 \mathrm{~kg}[8.4 \mathrm{lb}])$ of combustible materials such as wood, plastics, and paper. 
Some of the acetone is assumed to spill onto the hot plate, flash vaporize, and explode. The energy from the explosion is assumed to be great enough, and the three bottles of toxic chemicals are assumed to be close enough to the explosion to cause the bottles to shatter. About 6 percent of the contents of each of the bottles is assumed to be released as aerosol. The explosion is assumed to ignite the combustible material. The hydrofluoric acid is assumed to degrade the HEPA filters rendering them useless, and thus allowing the release of the toxic aerosols and gases. The estimated consequences of this release are listed in Table 6-2.

Table 6-2. 324 Building Non-Radiological Accident Consequence.

\begin{tabular}{|c|l|c|c|c|}
\hline \multirow{2}{*}{ Chemical } & \multirow{2}{*}{ Receptor } & $\begin{array}{c}\text { Concentration } \\
\left(\mathrm{mg} / \mathrm{m}^{3}\right)\end{array}$ & \multicolumn{2}{|c|}{$\begin{array}{c}\text { Exposure limits } \\
\left(\mathrm{mg} / \mathrm{m}^{3}\right)\end{array}$} \\
& & & TWA $^{\mathrm{a}}$ & $\mathrm{IDLH}^{\mathrm{b}}$ \\
\hline \multirow{2}{*}{$\mathrm{HF}$ (as F) } & Onsite MI & 2.2 & 2.60 & 24.9 \\
\cline { 2 - 3 } & Offsite MI & 0.41 & & \\
\hline \multirow{2}{*}{$\mathrm{As}_{2} \mathrm{O}_{3}$ (as) } & Onsite MI & 0.20 & 0.20 & 100 \\
\cline { 2 - 3 } & Offsite MI & 0.039 & & \\
\hline \multirow{2}{*}{$\mathrm{Ni}$} & Onsite MI & 0.27 & \multirow{2}{*}{1.0} & \multirow{2}{*}{ N/A } \\
\cline { 2 - 3 } & Offsite MI & 0.05 & & \\
\hline
\end{tabular}

${ }^{3}$ The time-weighted average (TWA) is the average concentration for a normal 8-hour workday and a 40-hour work week to which nearly all workers may be repeatedly exposed, day after day, without adverse effect.

${ }^{b}$ Immediately dangerous to life and health (IDLH) refers to the highest concentration to which an individual may be exposed for up to 30 minutes without experiencing escapeimpairing symptoms or irreversible health effects.

$\mathrm{N} / \mathrm{A}=$ Not applicable

\subsubsection{Radiological Liquid Releases}

No scenarios were identified for radiological liquid releases.

\subsubsection{Non-Radiological Liquid Releases}

No scenarios were identified for nonradiological liquid releases. 
WHC-SD-SNF-TI-002, Rev. 0

\subsection{BUILDING}

\subsection{GENERAL INFORMATION}

The 325 Building was designed to provide space for radiochemical research. The 325 Building, located in the 300 Area of the Hanford Site, houses the 325-A High-Level Radiochemistry Facility and the 325-B Shielded Analytical Laboratory. The 325 Building consists of (1) a central portion (completed in 1953) containing general-purpose laboratories modified for low-level radiochemical work by provision of special ventilation and work enclosures; (2) a south (front) wing containing office space, locker rooms, lunch room, and maintenance shops; and (3) east and west wings provided with shielded enclosures and remote manipulators for high-level radiochemical work. The 325 Building is shown schematically in Figures 7-1 through 7-4.

The building frame is welded steel. The parapeted roof has a slightly sloped steel deck with a tar and gravel finish. Exterior walls are industrial-insulated panels of fluted steel. The basement floor is painted concrete; the first and second floors are steel decks topped with concrete and finished with vinyl sheet or tile. The first floor is designed for a $970-\mathrm{kg} / \mathrm{m}^{3}\left(200-\mathrm{lb} / \mathrm{ft}^{2}\right)$ loading. Most original laboratory partitions are of a metal, movable type that is decontaminable in that the joints present minimum-sized cracks. All new construction, replacements, and modification of partitions are metal stud, dry-wall-type installations. Some second-floor and basement partitions are concrete or concrete block. Suspended ceilings are perforated metal pans backed with rock wool pads or acoustical fire resistant (A202) panels. Fixed windows protected by storm sashes and shade screens extend across the front of the south wing.

The central portion of the building is $59.1 \mathrm{~m} \times 59.8 \mathrm{~m}$ (194 ft $\times 196 \mathrm{ft}$ ) on three floors (basement, ground, and second) and contains over 100 laboratories and offices. The south wing is $22.6 \mathrm{~m} \mathrm{x} 40.5 \mathrm{~m}$ (74 ft $\times 133 \mathrm{ft}$ ) on two floors and contains offices, conference room, machine shop, lunch room, and rest rooms. The east wing of the 325 Building (325-A), known as the High-Level Radiochemistry Facility, is $14.6 \mathrm{~m} \mathrm{x} 39.6 \mathrm{~m} \mathrm{(48} \mathrm{ft} \mathrm{x}$

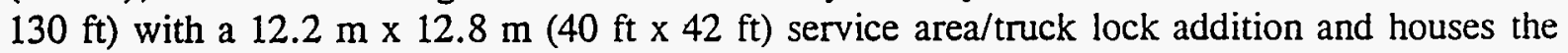
process research hot cells, truck lock, and manipulator repair. The west wing of the 325 Building (325-B), known as the Shielded Analytical Laboratory, is $16.2 \mathrm{~m} \times 16.5 \mathrm{~m}$ $(53 \mathrm{ft} \mathrm{x} 54 \mathrm{ft}$ ) and houses additional process research hot cells. Small-irradiated fuel pieces are stored in the hot cells in both the High-Level Radiochemistry Facility and the Shielded Analytical Laboratory. 
WHC-SD-SNF-TI-002, Rev. 0

Figure 7-1. 325 Building Floor Plan.

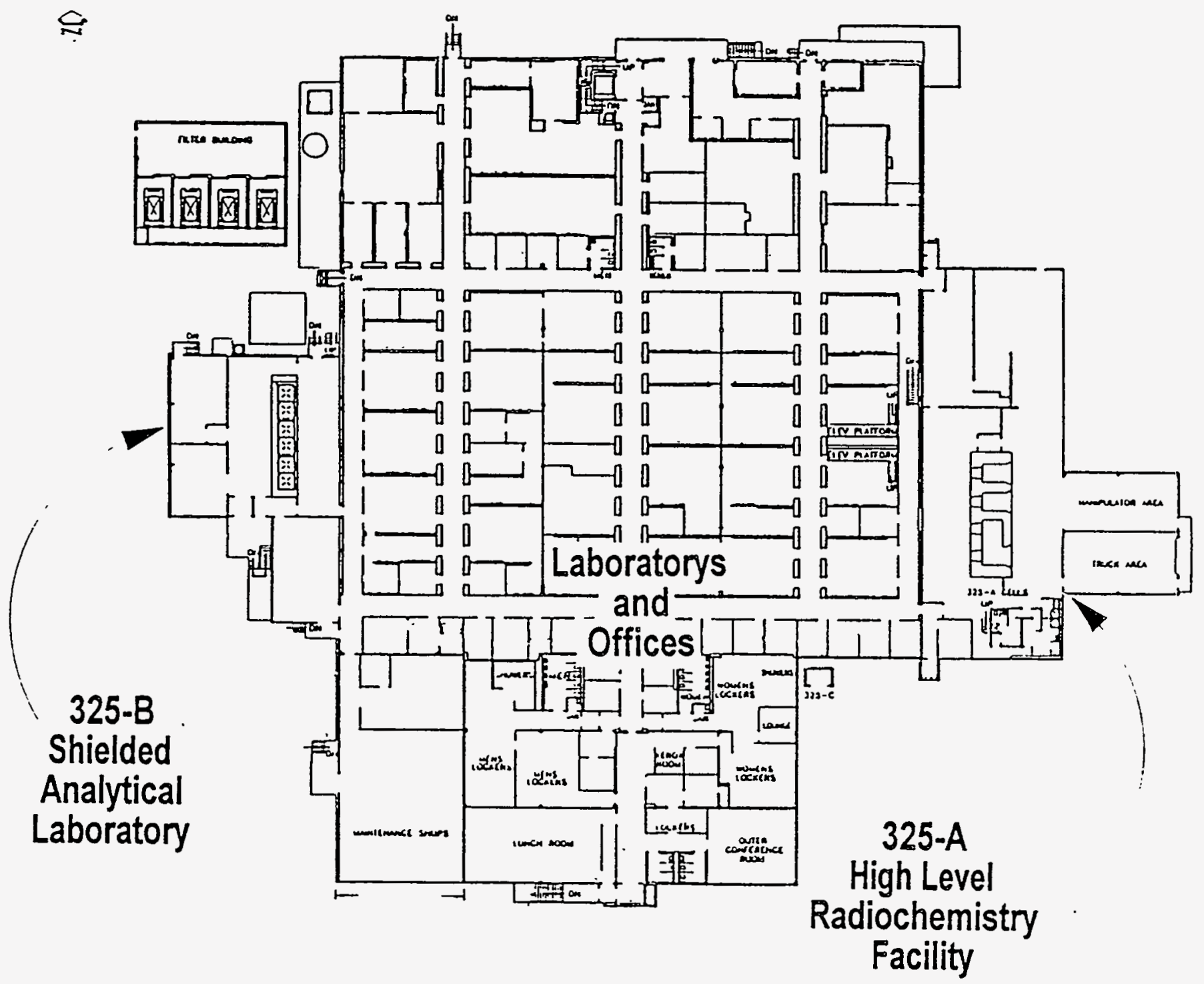


WHC-SD-SNF-TI-002, Rev. 0

Figure 7-2. 325-A High-Level Radiochemistry Facility Floor Plan.

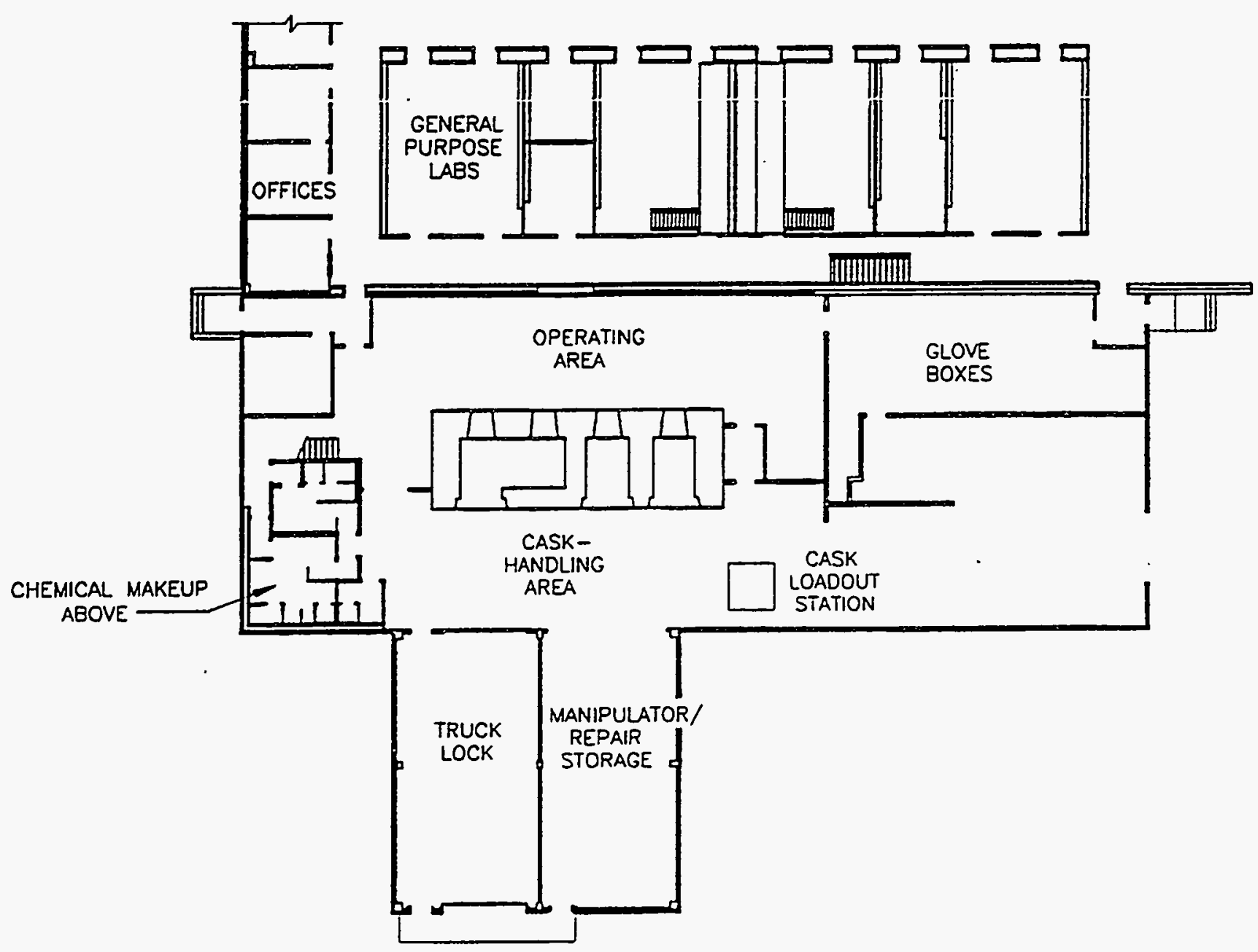


WHC-SD-SNF-TI-002, Rev. 0

Figure 7-3. High-Level Radiochemistry Facility Cutaway (325 Building).

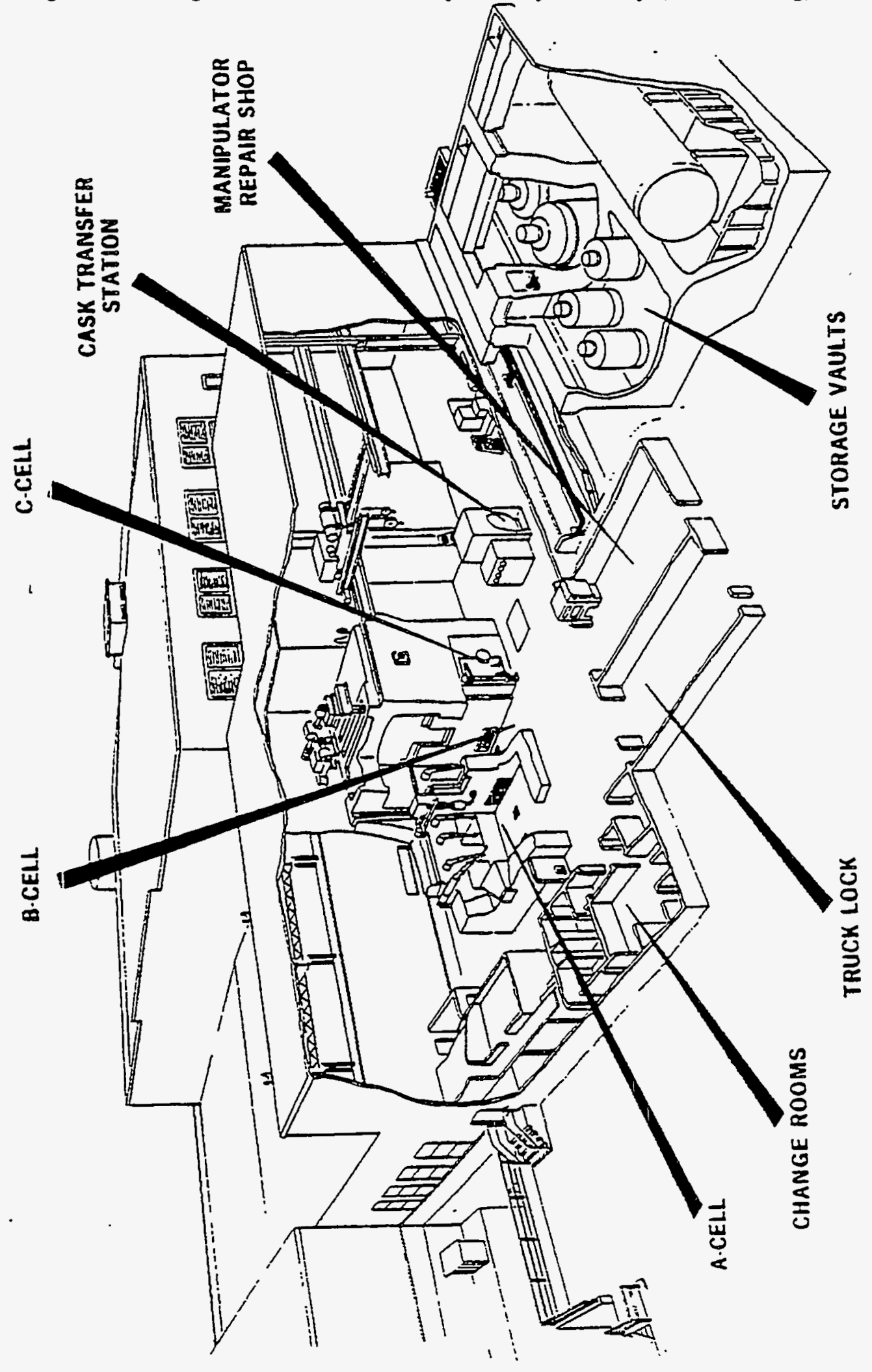


Figure 7-4. 325-B Shielded Analytical Laboratory Floor Plan.

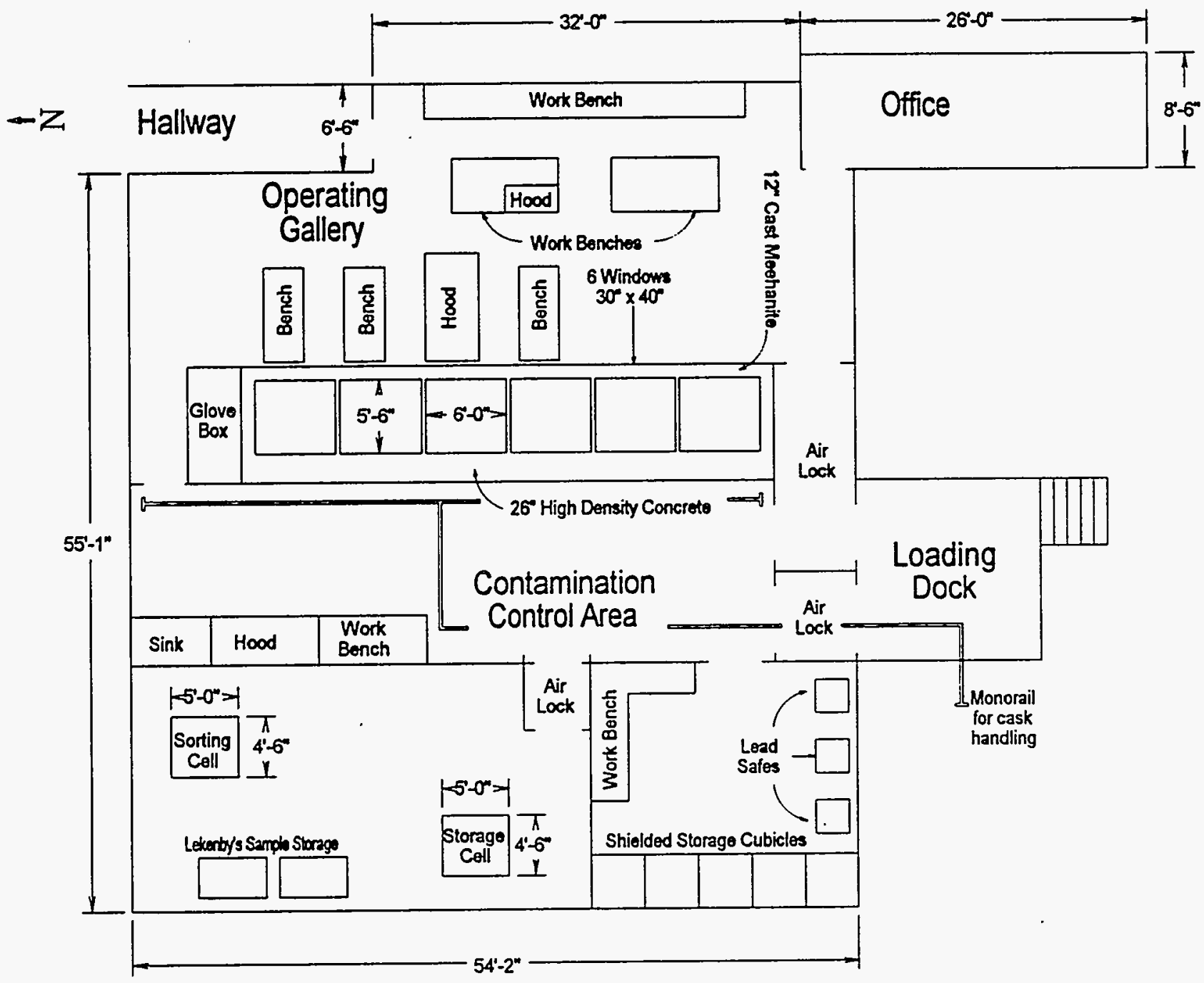




\subsection{5-A HIGH-LEVEL RADIOCHEMISTRY FACILITY}

The High-Level Radiochemistry Facility contains three interconnecting cells (A, B, and $C$ cells) and supporting facilities for work with megacuries of radionuclides. Two of the cells have inside dimensions of $1.8 \mathrm{~m}(6 \mathrm{ft})$ wide $\times 4.6 \mathrm{~m}(15 \mathrm{ft})$ high $\times 2.1 \mathrm{~m}(7 \mathrm{ft})$ deep; the third cell has inside dimensions of $4.6 \mathrm{~m}(15 \mathrm{ft})$ wide $\times 4.6 \mathrm{~m}(15 \mathrm{ft})$ high $\times 2.1 \mathrm{~m}(7 \mathrm{ft})$ deep. The three cells are enclosed in a $25-\mathrm{m} \times 14.6-\mathrm{m}$ (82-ft $\times 48-\mathrm{ft}$ ) steel-framed, reinforced-concrete structure. These cells are shielded with walls of $1.2-\mathrm{m}-(4-\mathrm{ft}-)$ thick, high-density concrete on the front and sides and $0.9-\mathrm{m}$ - (3-ft-) thick, high-density concrete on the back. Remote operation of the cell equipment is performed in the "front face" operating gallery; movement of materials takes place in the rear support gallery. The rear support gallery also provides access to the cells. The cells are ventilated by air drawn from the rear face gallery and exhausted through testable HEPA filters. The cells are constructed on the first-floor level and supported by heavy reinforced-concrete piers, columns, and pilasters. The basement level contains exhaust ducting, HEPA filters, and other miscellaneous services to the cells. The front side contains manipulators, service ports, and high-density lead-glass windows having equivalent shielding to that of the walls. Each cell has a $45.7-\mathrm{cm}$ - (18-in.-) thick Meehanite iron door shielding the main entrance and other smaller entry ports on the back.

B cell currently contains a core extruder and analytical measuring equipment used for the tank waste characterization program. A cell is currently being renovated, and when finished, will take the place of B cell (which will be used for characterization of single-shell tank waste). B cell is scheduled for renovation starting in fiscal year 1995. C-cell renovation is complete, and $\mathrm{C}$ cell is currently being used for characterization work.

\subsection{5-B SHIELDED ANALYTICAL LABORATORY}

The 325-B Shielded Analytical Laboratory contains six interconnecting "hot" cells and two separate hot cells. The interconnecting cells are $1.7-\mathrm{m} \times 1.7-\mathrm{m}(5.5-\mathrm{ft} \times 5.5-\mathrm{ft})$ compartments inside shielding walls. These compartments are divided into three groups of two compartments each, separated by hollow 10.2-cm- (4-in.-) thick sheet metal dividers. The shielding walls on the east and north sides of the cells are $30.5 \mathrm{~cm}$ (12 in.) of Meehanite iron. Shielding walls on the west and south sides are $66 \mathrm{~cm}$ (26 in.) of magnetite concrete. The east side of each compartment is equipped with two manipulators and with high-density, lead-glass viewing windows having the same shielding effect as the walls. These compartments are used for analytical chemistry operations on small amounts of highly radioactive materials such as samples of single-shell tank waste. Operations within the cells are by manipulator or other remote equipment. The other two hot cells are in a separate

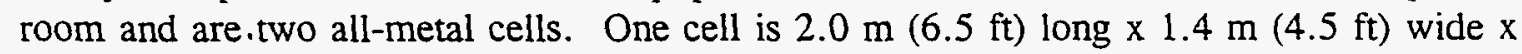
$2.5 \mathrm{~m}(8.2 \mathrm{ft})$ high inside dimensions, with $15-\mathrm{cm}$ - (6-in.-) thick walls and roof. The other cell is $1.7 \mathrm{~m}(5.6 \mathrm{ft})$ long $\times 1.5 \mathrm{~m}(5 \mathrm{ft})$ wide $\times 1.5 \mathrm{~m}(5 \mathrm{ft})$ high inside dimensions, with 
15-cm- (6-in.-) thick walls and roof. This cell sits on a pedestal that is $81 \mathrm{~cm}$ (32 in.) above the floor. Both cells have shielded viewing windows, two master slave manipulators, an access door, and a pass-through port.

\subsection{IRRADIATED FUEL STORAGE AT THE 325 BUILDING}

Irradiated fuel is stored in the 325 Building only because there is no currently approved process for moving the fuel and no location prepared to accept the fuel. The irradiated fuel does not support any current mission in the 325 Building.

Numerous small pieces of irradiated fuel are stored on shelves in the $B$ and $C$ hot cells of the 325-A High-Level Radiochemistry Facility and hot cells of the 325-B Shielded Analytical Laboratory. The B and C hot cells of the 325-A High-Level Radiochemistry Facility contain irradiated fuel having approximately $5.6 \mathrm{~kg}(12 \mathrm{lb})$ of uranium. The hot cells of the 325-B Shielded Analytical Laboratory contain irradiated fuel having approximately $4.9 \mathrm{~kg}(11 \mathrm{lb})$ of uranium.

\subsection{TRANSPORTATION}

Although there are rail spurs in the 300 Area, no direct rail access to the 325 Building is available. Any movement of materials to or from the facility would need to be done by truck. The $325-\mathrm{A}$ wing has an overhead crane with 27 metric tons (30 tons) capacity and the 325-B wing has an overhead crane with 2.7 metric tons ( 3 tons) capacity, which could be used to move the fuel inside the building.

\subsection{ESTIMATED STAFF SIZE AND OPERATIONAL COST}

\subsubsection{Estimated Staff Size}

There are approximately 150 people working in the 325 Building including scientists, technicians, managers, administrative professionals, operators, and craftspersons. There are no daily activities which involve the fuel. The fuel is inventoried semi-annually, and remains undisturbed in storage the remainder of the time. Less than one full time staff equivalent is required for direct support to irradiated fuel storage activities in the building.

\subsubsection{Estimated Operational Cost}

Operational costs are highly dependent on nonfuel storage program activities within the 325 Building facility. A rough estimate of the total operating cost is derived by multiplying the number of occupants in the building by the estimated average cost per 
employee per year. The average cost per PNL employee is $\$ 150,000 /$ year; thus, the estimated annual operation and maintenance cost for the 325 Building is $\$ 23$ million. The fuel storage costs are estimated to be less than $\$ 100,000 /$ year.

\subsection{ESTIMATED OPERATIONAL DOSE COMMITMENT (PNL 1993a)}

Dose information for the 325 Building is included in the overall dose measurements for all Hanford Site PNL facilities, and is not tabulated alone. The dose rate for all Hanford Site PNL facilities includes the dose rate for the 324, 325 and 327 Buildings, among others, and is only given as a total. Since the majority of PNL work with highly radioactive materials at the Hanford Site is performed in the 324, 325, and 327 Buildings, most of the dose rate occurs in these three facilities. The totals for PNL facilities are as follows: 68 man-rem in 1990; 52 man-rem in 1991; and 58 man-rem in 1992. The total dose rate in 1992 was shared among 693 workers as follows: 552 workers received from 1 to 99 mrem, 64 workers received from 100 to 250 mrem, 43 workers received from 250 to $500 \mathrm{mrem}$, 20 workers received from 500 to 750 mrem, 8 workers received from 750 to 1,000 mrem, and 6 workers received from 1,000 to 2,000 mrem.

Spent fuel storage in the 324,325 , and 327 Buildings is in hot cells, casks or pools, which effectively limit worker exposure. The dose rate to workers resulting from spent fuel storage is only a small fraction of the total.

\subsection{ESTIMATED ROUTINE ENVIRONMENTAL RELEASES}

The estimated environmental releases have been divided into four categories as follows:

- Radiological airborne emissions

- Nonradiological airborne emissions

- Radiological liquid effluents

- Nonradiological liquid effluents.

\subsubsection{Radiological Airborne Emissions}

Environmental releases from the operation of the 325 Building for calendar years 1990, 1991, and 1992 are presented in Table 7-1. Radionuclide air emissions for the 325 Building main stack are provided in Section 7.7.3. This stack exhausts filtered building air. The exhaust is sampled for particulate alpha and beta radioactivity, ${ }^{131} \mathrm{I}$, and tritium. At present, no source of ${ }^{131} \mathrm{I}$ exists in the building. 
Table 7-1. 325 Building Airborne Radionuclide Releases.

\begin{tabular}{|l|c|c|c|}
\hline \multicolumn{1}{|c|}{ Radionuclide } & $\begin{array}{c}1992 \text { totals (Ci) } \\
\text { (DOE-RL 1993b) }\end{array}$ & $\begin{array}{c}1991 \text { totals (Ci) } \\
\text { (DOE-RL 1992) }\end{array}$ & $\begin{array}{c}1990 \text { totals (Ci) } \\
\text { (DOE-RL 1991) }\end{array}$ \\
\hline${ }^{3} \mathrm{H}\left(\right.$ as H $\left.\mathrm{H}_{2} \mathrm{O}\right)$ & $2.5 \mathrm{E}+01 \mathrm{Ci}$ & $5.4 \mathrm{E}+01 \mathrm{Ci}$ & $4.3 \mathrm{E}-01 \mathrm{Ci}$ \\
\hline${ }^{3} \mathrm{H}\left(\right.$ as H $\left.\mathrm{H}_{2}\right)$ & $7.0 \mathrm{E}+00 \mathrm{Ci}$ & $2.9 \mathrm{E}+01 \mathrm{Ci}$ & $9.2 \mathrm{E}+00 \mathrm{Ci}$ \\
\hline Total alpha $^{\mathrm{a}}$ & $8.5 \mathrm{E}-07 \mathrm{Ci}$ & $1.6 \mathrm{E}-06 \mathrm{Ci}$ & $1.6 \mathrm{E}-06 \mathrm{Ci}$ \\
\hline Total beta & $2.4 \mathrm{E}-06 \mathrm{Ci}$ & $9.9 \mathrm{E}-05 \mathrm{Ci}$ & $4.1 \mathrm{E}-05 \mathrm{Ci}$ \\
\hline Total flow & $1.8 \mathrm{E}+09 \mathrm{~m}^{3}$ & $1.9 \mathrm{E}+09 \mathrm{~m}^{3}$ & Not available \\
\hline
\end{tabular}

${ }^{2}$ Total alpha and total beta counts are for particulate only.

\subsubsection{Non-Radiological Airborne Emissions}

There is no.routine monitoring of nonradioactive releases for the 325 Building. Any releases which might occur have not been considered to be significant, and therefore no constituents are measured.

\subsubsection{Building Stack Information (DOE-RL 1993b)}

Stack Height: $17.9 \mathrm{~m} \mathrm{(59 \textrm {ft } )}$

Flow rate: $3.46 \times 10^{6}$ to $3.68 \times 10^{6} \mathrm{~L} / \mathrm{min}\left(122,000\right.$ to $\left.130,000 \mathrm{ft}^{3} / \mathrm{min}\right)$

Diameter: $2.4 \mathrm{~m}(8 \mathrm{ft})$

Temperature: 13 to $24 \circ \mathrm{C}(55$ to $75 \circ \mathrm{F})$

\subsubsection{Radiological Liquid Effluents}

There are no routine liquid effluent streams resulting from irradiated fuel storage at the 325 Building.

\subsubsection{Non-Radiological Liquid Effluents}

There are no routine liquid effluent streams resulting from irradiated fuel storage at the 325 Building. 
WHC-SD-SNF-TI-002, Rev. 0

\subsection{BOUNDING ACCIDENT SCENARIO AND RELATED ENVIRONMENTAL RELEASES (PNL 1992a)}

A severe earthquake (without subsequent fire) is the bounding credible accident. It is postulated that an earthquake causes windows to break but does not cause general or local structural collapse. Doors may be jammed open after building evacuation; leaving additional openings for unfiltered releases. Building power and/or heating, ventilation, and airconditioning operation could be lost. Further damage would be caused to gloveboxes and the contents of shelves and cabinets. The expected effects are considered to be the most severe that could result from a $0.135 \mathrm{G}$ horizontal acceleration, corresponding to the $2 \times 10^{-4}$ per year seismic event for which protection is required by DOE design criteria for a new structure.

\subsubsection{Radiological Airborne Release}

The radiological consequences of an extreme seismic event have been estimated to be an effective dose equivalent of $0.24 \mathrm{rem}$ to the offsite individual (at $580 \mathrm{~m}$ ) and $2.3 \mathrm{rem}$ to the onsite individual (at $100 \mathrm{~m}$ ). The specific nuclides and activities are as follows:

Activity Released in the First 2 hours from the Earthquake Scenario

$\begin{array}{lll}\text { Radionuclide } & \text { Ci } \\ { }^{3} \mathrm{H} & & 0.0425 \\ { }^{85} \mathrm{Kr} & 66.2\end{array}$

$\underline{\text { Radionuclide }} \underline{\text { TRU as nitrate ( } \mathrm{Ci} \text { ) }} \quad \underline{\mathrm{TRU} \text { as oxide (Ci) }}$

$\begin{array}{lll}{ }^{232} \mathrm{Th} & 2.23 \mathrm{E}-10 & 2.32 \mathrm{E}-06 \\ { }^{238} \mathrm{U} & 1.04 \mathrm{E}-08 & 4.17 \mathrm{E}-05 \\ { }^{235} \mathrm{U} & 5.34 \mathrm{E}-10 & 1.16 \mathrm{E}-06 \\ { }^{233} \mathrm{U} & 1.36 \mathrm{E}-06 & 4.68 \mathrm{E}-07 \\ { }^{237} \mathrm{~Np} & 6.88 \mathrm{E}-07 & 2.36 \mathrm{E}-07 \\ { }^{238} \mathrm{Pu} & 0.002016 & 0.000772 \\ { }^{239} \mathrm{Pu} & 0.002047 & 0.001203 \\ { }^{240} \mathrm{Pu} & 0.001037 & 0.000609 \\ { }^{241} \mathrm{Pu} & 0.051751 & 0.030407 \\ { }^{241} \mathrm{Am} & 0.000877 & 0.000343 \\ { }^{242} \mathrm{Pu} & 2.88 \mathrm{E}-07 & 1.65 \mathrm{E}-07 \\ { }^{243} \mathrm{Am} & 2.09 \mathrm{E}-05 & 7.17 \mathrm{E}-06 \\ { }^{244} \mathrm{Cm} & 0.003130 & 0.001075\end{array}$


WHC-SD-SNF-TI-002, Rev. 0

Activity Released after the first 2 hours but within the first 4 days from the Earthquake scenario

$\underline{\text { Radionuclide }}$ TRU as nitrate (Ci) TRU as oxide (Ci)

$\begin{array}{lll}{ }^{232} \mathrm{Th} & 4.08 \mathrm{E}-10 & 2.01 \mathrm{E}-06 \\ { }^{238} \mathrm{U} & 1.91 \mathrm{E}-08 & 3.61 \mathrm{E}-05 \\ { }^{235} \mathrm{U} & 9.76 \mathrm{E}-10 & 1 \mathrm{E}-06 \\ { }^{233} \mathrm{U} & 7.08 \mathrm{E}-07 & 3.49 \mathrm{E}-07 \\ { }^{237} \mathrm{~Np} & 3.58 \mathrm{E}-07 & 1.76 \mathrm{E}-07 \\ { }^{238} \mathrm{Pu} & 0.002231 & 0.000614 \\ { }^{239} \mathrm{Pu} & 0.008545 & 0.001143 \\ { }^{240} \mathrm{Pu} & 0.004329 & 0.000579 \\ { }^{241} \mathrm{Pu} & 0.216022 & 0.028896 \\ { }^{241} \mathrm{Am} & 0.001077 & 0.000276 \\ { }^{242} \mathrm{Pu} & 1.41 \mathrm{E}-06 & 1.56 \mathrm{E}-07 \\ { }^{243} \mathrm{Am} & 1.08 \mathrm{E}-05 & 5.34 \mathrm{E}-06 \\ { }^{244} \mathrm{Cm} & 0.001626 & 0.000801\end{array}$

\subsubsection{Non-Radiological Airborne Release}

Toxicological consequences were also estimated for the bounding accident scenario. The toxicological consequences are derived from the onsite and offsite concentrations produced by the seismic event. The concentrations result from the spilling or evaporation of a substantial part of the 325 Building hazardous chemical inventory, and release of the inventory through openings in the building's skin. The onsite (100 m [330 ft]) and offsite (580 $\mathrm{m}[1,900 \mathrm{ft}]$ ) concentrations of each chemical were divided by the toxicological limit concentrations appropriate for the chemical for an unlikely event. The PNL approach for chemical hazards assessment is defined in PNL-MA-44 (PNL 1993b). These concentration ratios were summed to give a ratio representing how close the total was to exceeding the limit. This is a conservative procedure for estimating toxicological consequences, because not all of the chemicals act on the same organs and so are not necessarily additive. The sum over all the significant inventory of chemicals were 99 percent of the guidelines for the 15-minute onsite concentration and 26 percent for the 15 -minute offsite concentration, indicating that the limits are not exceeded.

It is important to note that the environmental releases associated with the earthquake scenario are from all sources in the 325 Building, but the irradiated fuel is only a small fraction of the total.

\subsubsection{Radiological and Non-Radiological Liquid Releases}

No estimates of radiological or nonradiological liquid releases were available. 
WHC-SD-SNF-TI-002, Rev. 0

This page intentionally left blank. 


\subsection{BUILDING}

\subsection{GENERAL INFORMATION}

The 327 Building is located in the 300 Area of the Hanford Site. The 327 Building, also known as the Postirradiation Testing Laboratory, provides shielded, ventilated, and specially equipped laboratories for physical and metallurgical examination and testing of irradiated fuels, concentrated fission products, and structural materials. The irradiated fuel examined consists primarily of fuel pins containing plutonium and uranium oxides. Other fuel forms such as metal, carbides, and nitrides are handled occasionally. The irradiated fuel is held in either shielded cells and two small water pools before testing and before shipment for recovery or retrievable storage. The 327 Building is shown schematically in Figures 8-1 through 8-4.

The 327 Building is a single-story structure with a partial basement. Maximum dimensions are $65.5 \mathrm{~m}(215 \mathrm{ft})$ long $\mathrm{x} 42.7 \mathrm{~m}(140 \mathrm{ft})$ wide $\mathrm{x} 9.8 \mathrm{~m}(32 \mathrm{ft})$ tall and the building is roughly cruciform in shape. The total work area is approximately $2,330 \mathrm{~m}^{2}$ $\left(25,000 \mathrm{ft}^{2}\right)$ with $929 \mathrm{~m}^{2}\left(10,000 \mathrm{ft}^{2}\right)$ of laboratory. and work areas; $195 \mathrm{~m}^{2}\left(2,110 \mathrm{ft}^{2}\right)$ of offices; $223 \mathrm{~m}^{2}\left(2,410 \mathrm{ft}^{2}\right)$ of storage areas; and $975 \mathrm{~m}^{2}\left(10,500 \mathrm{ft}^{2}\right)$ of common areas containing ventilation and auxiliary equipment. The building framework is welded steel. The exterior walls are fluted-steel insulated panels. The primary operating area is on the main floor and includes 11 hot cells, two small shielded cells, two small water pools, the area around the cells (the canyon), and the bays connected to the canyon in which auxiliary operations are performed.

A 13.5-metric-ton (15-ton) bridge crane and an 18-metric-ton (20-ton) bridge crane are used to transfer casks containing radioactive structural materials or fuel from the receiving area to the cells or between the cells, and for general lifting and transfer service in the canyon.

Materials unaffected by air are examined and tested in shielded cells with an air atmosphere. Cells A through I are shop-fabricated from high-density cast iron (Meehanite). The base, walls, and top cover are fitted together by a groove-dowel, lock-together design. The shielded cells rest on a reinforced-concrete floor. If direct access is required, a wall may be removed to permit maintenance or to make changes in process or handling equipment.

Most operations in the cells are performed with manipulators. Spaced symmetrically about the iron cell walls are interchangeable plugs that lock in place by expanding retaining rings. The interchangeable plugs are used to connect services and for viewing ports into the cell. 
Figure 8-1. Postirradiation Testing Laboratory Floor Plan (327 Building).

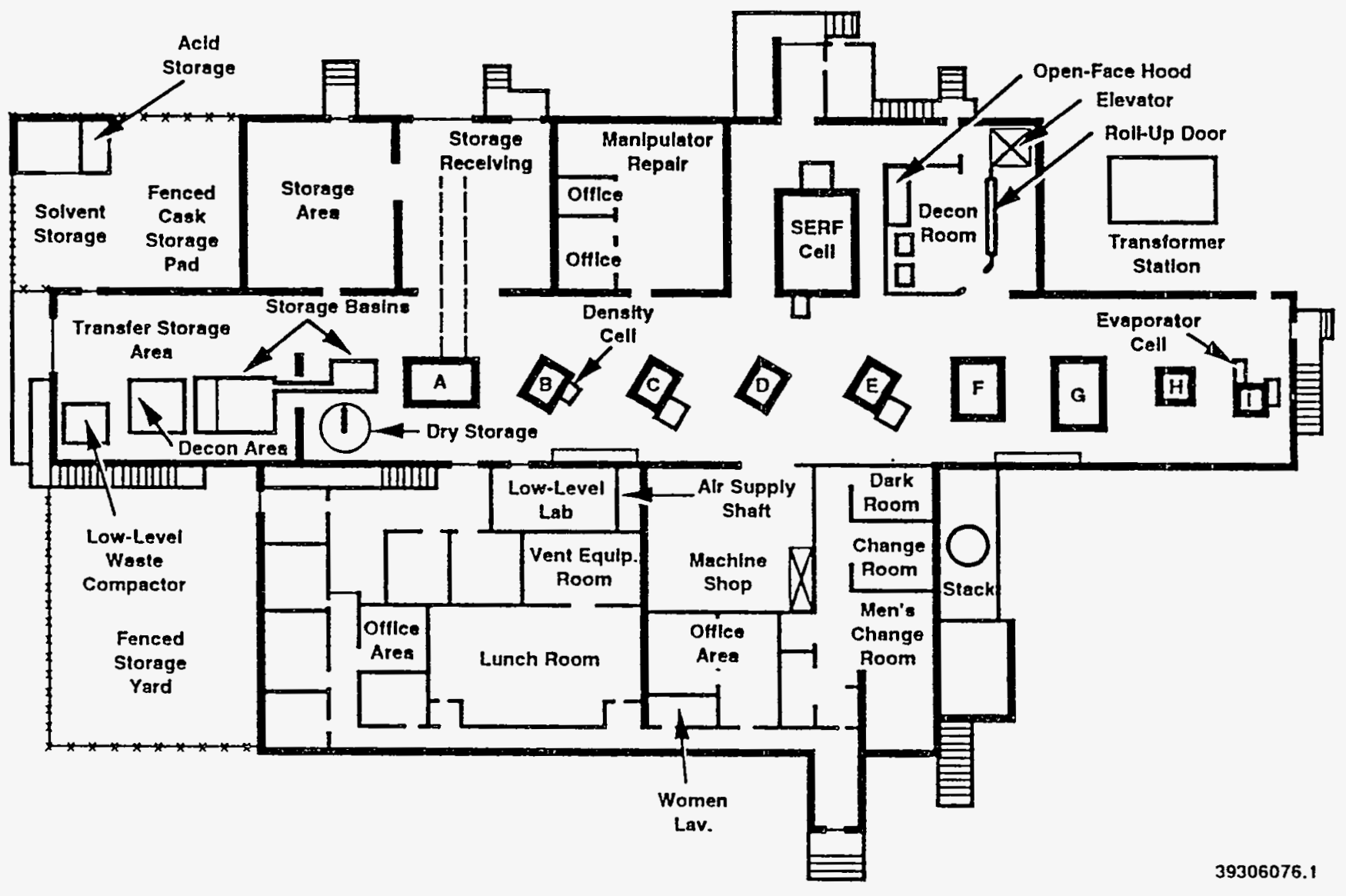


Figure 8-2. Postirradiation Testing Laboratory Hot Cells (327 Building).

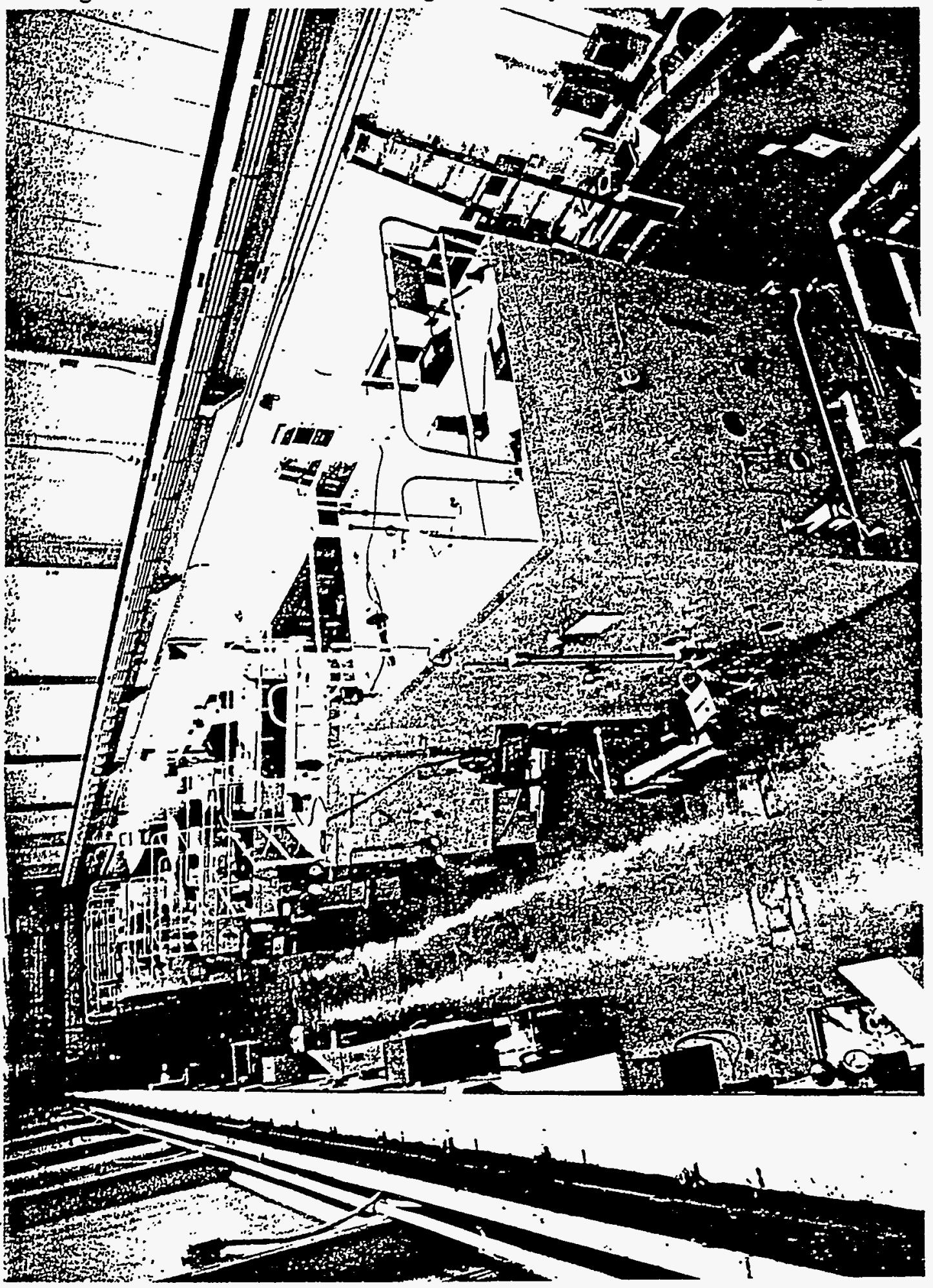


Figure 8-3. High-Level Utility Cell (327 Building).

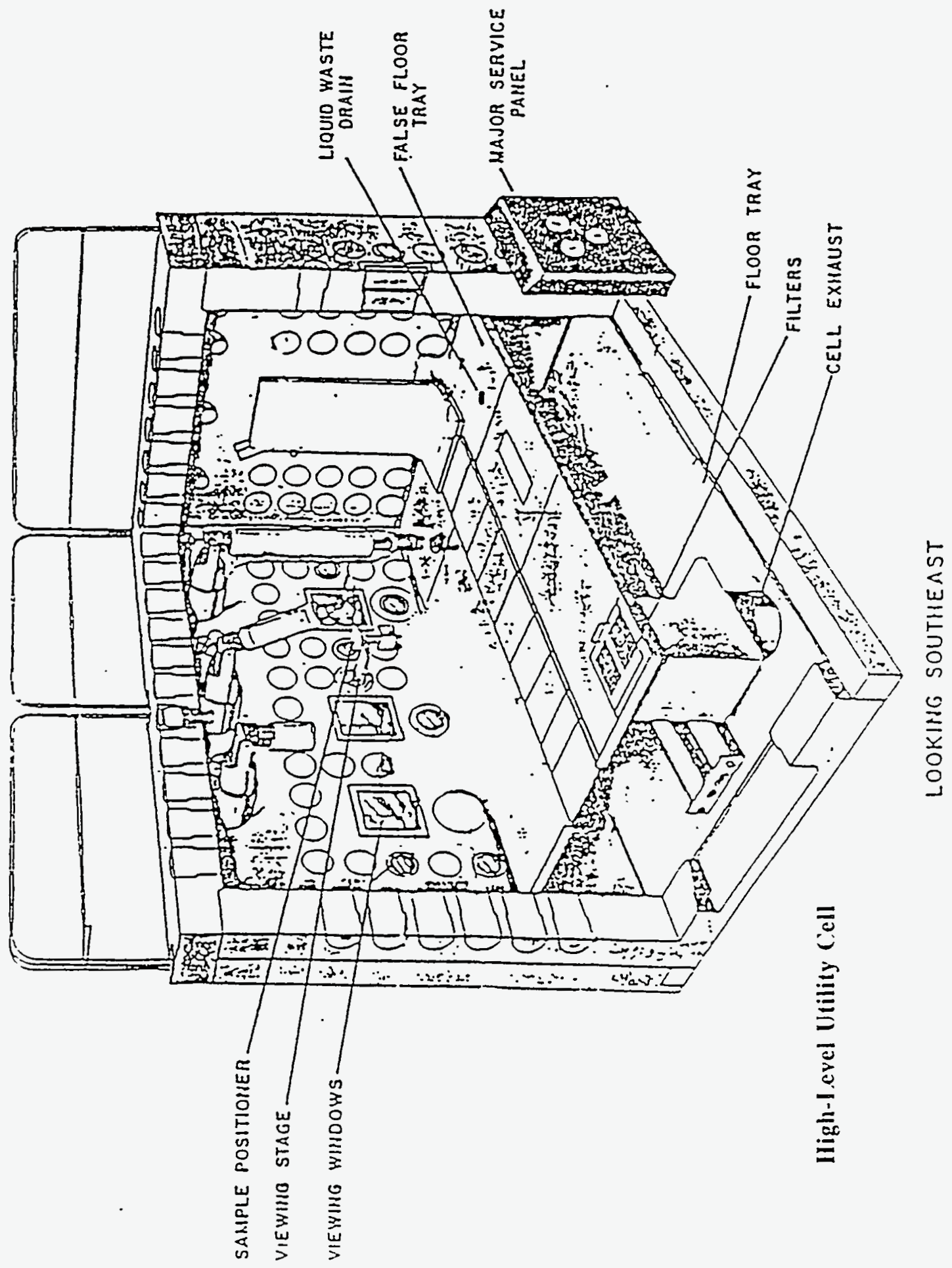


Figure 8-4. Special Environmental Radiometallurgy Facility Cell (327 Building).

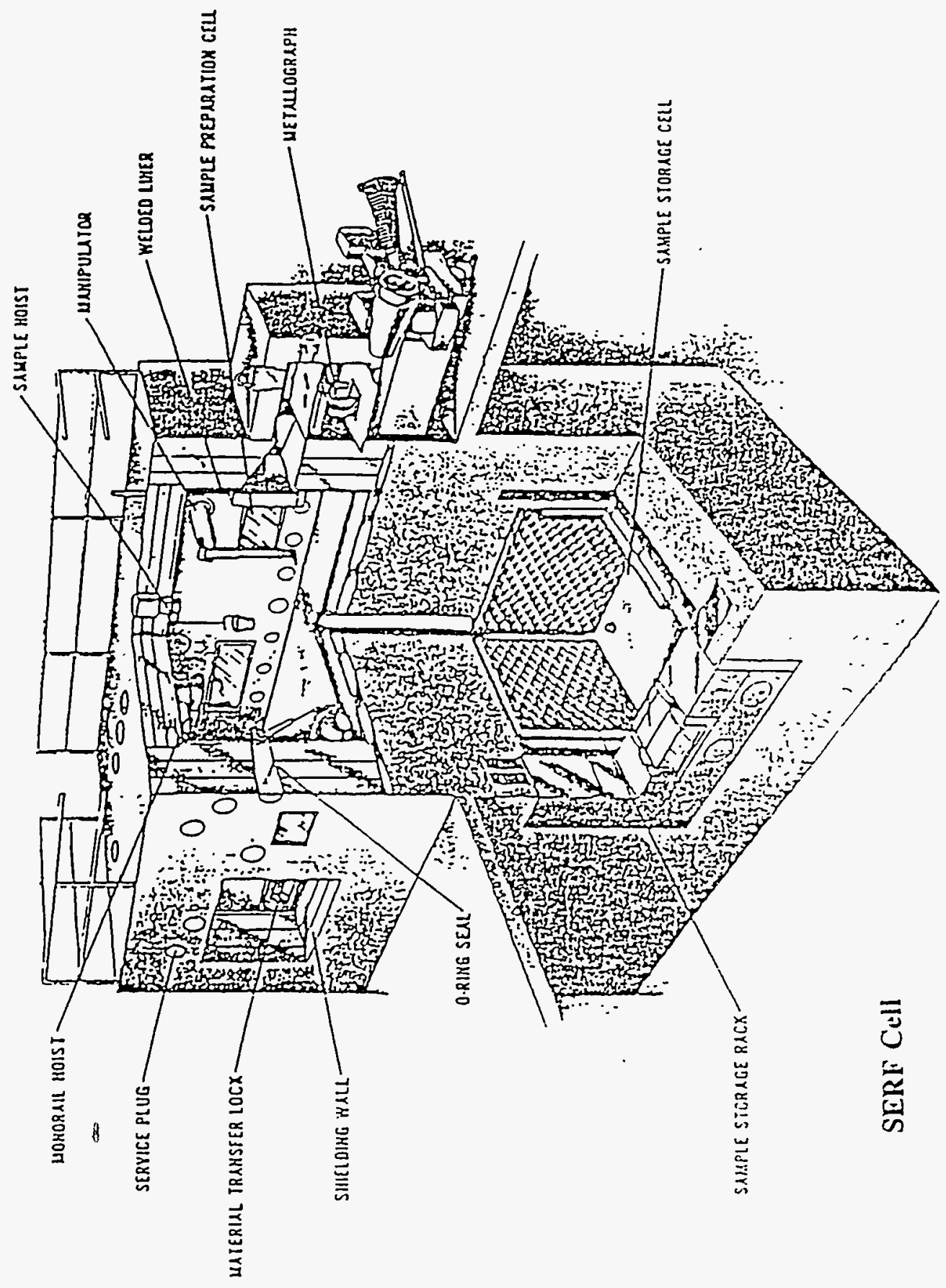


The two lead-brick shielded cells are used for density determination and for deposition of surface films for electron microprobe studies.

The Special Environmental Radiometallurgy Facility (SERF) cell provides an examination and storage facility with a nitrogen atmosphere for specimens that may be affected by air. The facility consists of an upper operating area and a small lower storage area. A detachable shielded enclosure at the north end, with access to the operating cell, houses a remote metallograph for photomicrography, microhardness testing, and sample viewing at high magnification. Two airlocks provide access for entry or removal of test materials, supplies, equipment, and waste without compromising the integrity of the cell atmosphere. Operating equipment is designed to be located entirely within the cell, and operations are performed with manipulators.

The SERF storage cell is located in the basement and is connected to the operating area by a transfer tube. There is $1.75-\mathrm{m}-(5.74-\mathrm{ft}-)$ thick concrete between the ceiling of the storage cell and the floor of the main cell above. Shielding consists of $0.6 \mathrm{~m}(2 \mathrm{ft})$ of concrete on all sides with $10 \mathrm{~cm}$ (4 in.) of lead shielding on the north and west sides and $27 \mathrm{~cm}$ (11 in.) of steel on the operating (east) face. The south side is inaccessible since it is adjacent to a building support wall. A manipulator is provided to permit positioning and retrieval of materials in the storage area. Three storage racks are located in the cell on the wall opposite and on the two walls adjacent to the operating face of the cell. The racks accommodate 6.4-cm- (2.5-in.-) diameter $\times 10.2$-cm- (4-in.-) long sample cans and other smaller containers. The three storage racks contain a total of 460 locations.

The size, wall thickness, and construction materials for each of the hot cells is listed in Table $8-1$.

The purpose of the wet storage basins is to store incoming material before examination and out-going material before shipment. The larger storage basin is $3 \mathrm{~m}$ (10 ft) wide $\times 4.6 \mathrm{~m}(15 \mathrm{ft})$ long $\times 5.2 \mathrm{~m}(17 \mathrm{ft})$ deep, with an 2.6-m- (8.5-ft-) deep underwater

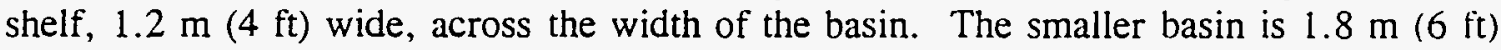
wide $\times 2.4 \mathrm{~m}(8 \mathrm{ft})$ long $\times 3 \mathrm{~m}(10 \mathrm{ft})$ deep. A canal, $0.5 \mathrm{~m}(1.5 \mathrm{ft})$ wide $\times 3 \mathrm{~m}(10 \mathrm{ft})$ deep, connects the large and smaller basins to facilitate movements of material from one storage basin to the other. Two 0.225 -metric-ton (500-lb) jib cranes, one serving each basin, are used to transfer materials in the basins. A transfer tube connects cell $A$ and the small basin. A mechanical sample carrier in the tube provides for sample transfers between cells and the basins. Water quality in the basins is maintained by molecular filters and mixed-bed deionizers.

Several racks in the larger basin are for storage of irradiated fuel and structural materials. There is one breeder reactor fuel pin storage rack, capable of holding up to 200 pins in a rigid array. The rack consists of 76-cm- (30-in-) long, $2.5-\mathrm{cm}-(1-$ in.-) diameter stainless steel tubes arranged in a $4 \times 50$ rectangular array. The tubes are welded into a box-like structure with a stainless steel frame and side panels. The rack sits on the 
Table 8-1. 327 Building Cells.

\begin{tabular}{|c|l|c|c|l|}
\hline Cell & \multicolumn{1}{|c|}{$\begin{array}{c}\text { Wall } \\
\text { material }\end{array}$} & $\begin{array}{c}\text { Wall } \\
\text { thickness } \\
(\mathrm{cm})\end{array}$ & $\begin{array}{c}\text { Inside dimensions } \\
(\mathrm{L} \times \mathrm{W} \times \mathrm{H}[\mathrm{cm}])\end{array}$ & Comments \\
\hline A & Cast iron & 46 & $290 \times 137 \times 249$ & $\begin{array}{c}\text { Connects with small } \\
\text { water storage basin }\end{array}$ \\
\hline B & Cast iron & 38 & $183 \times 132 \times 131$ & \\
\hline C & Cast iron & 27 & $183 \times 132 \times 131$ & \\
\hline D & Cast iron & 27 & $183 \times 132 \times 131$ & \\
\hline E & Cast iron & 27 & $183 \times 132 \times 131$ & \\
\hline F & Cast iron & 46 & $244 \times 152 \times 249$ & \\
\hline G & Cast iron & 27 & $312 \times 191 \times 253$ & \\
\hline H & Cast iron & 27 & $163 \times 140 \times 216$ & \\
\hline I & Cast iron & 27 & $132 \times 122 \times 157$ & \\
\hline Upper SERF & steel & 46 & $366 \times 183 \times 244$ & Nitrogen cover gas \\
\hline Lower SERF & $\begin{array}{l}\text { Concrete \& } \\
\text { lead or steel }\end{array}$ & $\begin{array}{c}61 \\
\text { L or } 27\end{array}$ & $122 \times 122 \times 152$ & Nitrogen cover gas \\
\hline Density & Lead brick & 15 & $91 \times 61 \times 61$ & Exhaust to cell B \\
\hline Evaporation & Lead brick & 15 & $76 \times 46 \times 46$ & Exhaust to cell I \\
\hline
\end{tabular}

basin floor with the storage tubes oriented vertically. A lifting ring is permanently attached to the top of the rack. The entire rack is $168 \mathrm{~cm}$ (66 in.) long, $61 \mathrm{~cm}$ ( 24 in.) wide, and $76 \mathrm{~cm}$ (30 in.) high. A wall rack for containers holding individual pins or structural specimens and a peg rack for holding tubing or duct material are located on the north wall of the large storage basin.

\subsection{IRRADIATED FUEL STORAGE AT THE 327 BUILDING}

Irradiated fuel is stored in the 327 Building only because there is no currently accepted process for moving the fuel and no location prepared to accept the irradiated fuel. The irradiated fuel does not support any current mission in the 327 Building.

There are $24.5 \mathrm{~kg}(54 \mathrm{lb})$ of irradiated fuel stored in the water basin and various hot cells of the Postirradiation Testing Laboratory. 
WHC-SD-SNF-TI-002, Rev. 0

\subsection{ESTIMATED STAFF SIZE AND OPERATIONAL COST}

\subsubsection{Estimated Staff Size}

There are approximately 21 full time staff located at the 327 building. This includes operating technicians, health physics technicians, craftspersons, engineering staff, management staff, receptionist/clerical staff, and a DOE representative. Although there are no daily activities that involve irradiated fuel, approximately one direct support staff is required for irradiated fuel storage incremental to the nonfuel storage activities.

\subsubsection{Estimated Operational Cost}

Costs are highly dependent on nonfuel storage program activities within the facility. Approximately $\$ 3.5$ million per year is required for maintenance and operation of the 327 Building. For fiscal year 1994, the budget is approximately $\$ 5.5$ million. The additional funds are to be used for special projects such as $\mathrm{N}$ Reactor fuel characterization.

\subsection{ESTIMATED OPERATIONAL DOSE COMMITMENT} (PNL 1993a)

Dose information for the 327 Building is included in the overall dose measurements for all Hanford Site PNL facilities, and is not tabulated alone. The dose rate for all Hanford Site PNL facilities includes the dose rate for the 324, 325 and 327 Buildings, among others, and is only given as a total. The majority of work with high dose rate materials at Hanford Site PNL facilities is performed in the 324,325 , and 327 Buildings. The totals for PNL facilities are as follows: 68 man-rem in 1990, 52 man-rem in 1991, and 58 man-rem in 1992. The total dose rate in 1992 was shared among 693 workers as follows: 552 workers received from 1 to $99 \mathrm{mrem}, 64$ workers received from 100 to $250 \mathrm{mrem}, 43$ workers received from 250 to $500 \mathrm{mrem}, 20$ workers received from 500 to $750 \mathrm{mrem}, 8$ workers received from 750 to $1,000 \mathrm{mrem}$, and 6 workers received from 1,000 to $2,000 \mathrm{mrem}$. The dose rate for 1992 for the 327 building was estimated at 4.7 man-rem². The average worker dose in the 327 Building is $260 \mathrm{mrem}$.

'Information obtained from Operations.

'Information obtained from the PNL ALARA Coordinator. 


\subsection{ESTIMATED ROUTINE ENVIRONMENTAL RELEASES}

The estimated environmental releases have been divided into four categories as follows:

- Radiological airborne emissions

- Nonradiological airborne emissions

- Radiological liquid effluents

- Nonradiological liquid effluents.

\subsubsection{Radiological Airborne Emissions}

Environmental releases from the operation of the 327 Building for calendar years 1990, 1991, and 1992 are given in Table 8-2. The 327 Building main stack exhausts filtered building air. The exhaust is sampled for particulate alpha and beta radioactivity and ${ }^{131} \mathrm{I}$. At present, no source of ${ }^{131} \mathrm{I}$ exists in the building.

Table 8-2. 327 Building Airborne Radionuclide Releases.

\begin{tabular}{|l|c|c|c|}
\hline Radionuclide & $\begin{array}{c}1992 \text { totals (Ci) } \\
\text { (DOE-RL 1993b) }\end{array}$ & $\begin{array}{c}1991 \text { totals (Ci) } \\
\text { (DOE-RL 1992) }\end{array}$ & $\begin{array}{c}1990 \text { totals (Ci) } \\
\text { (DOE-RL 1991) }\end{array}$ \\
\hline Total alpha $^{2}$ & $1.1 \mathrm{E}-07 \mathrm{Ci}$ & $4.7 \mathrm{E}-07 \mathrm{Ci}$ & $6.3 \mathrm{E}-07 \mathrm{Ci}$ \\
\hline Total beta $^{3}$ & $9.3 \mathrm{E}-07 \mathrm{Ci}$ & $1.3 \mathrm{E}-05 \mathrm{Ci}$ & $1.4 \mathrm{E}-05 \mathrm{Ci}$ \\
\hline Total flow & $7.7 \mathrm{E}+08 \mathrm{~m}^{3}$ & $7.9 \mathrm{E}+08 \mathrm{~m}^{3}$ & Not available \\
\hline
\end{tabular}

${ }^{2}$ Total alpha and total beta counts are for particulate only.

\subsubsection{Non-Radiological Airborne Emissions}

There is no routine monitoring of nonradioactive releases for the 327 Building. Any releases which might occur have not been considered to be significant, and therefore no constituents are measured.

\subsubsection{Building Stack Information (DOE-RL 1993b)}

Stack Height: $17.9 \mathrm{~m}(59 \mathrm{ft})$

Flow rate: $1,479,100 \mathrm{~L} / \mathrm{min}\left(52,228 \mathrm{ft}^{3} / \mathrm{min}\right)$

Diameter: $1.5 \mathrm{~m}(5 \mathrm{ft})$

Temperature: Room temperature, between 16 and $29 \circ \mathrm{C}(60$ and $85 \circ \mathrm{F})$. 
WHC-SD-SNF-TI-002, Rev. 0

\subsubsection{Radiological Liquid Effluents}

There are no routine liquid effluent streams resulting from irradiated fuel storage at the 327 Building.

\subsubsection{Non-Radiological Liquid Effluents}

There are no routine liquid effluent streams resulting from irradiated fuel storage at the 327 Building.

\subsection{BOUNDING ACCIDENT SCENARIO AND RELATED ENVIRONMENTAL RELEASES (HEDL 1985)}

\subsubsection{Radiological Airborne Release}

The postulated bounding accident for irradiated fuel storage is that of mechanical damage and subsequent fire of fuel pins of reactive fuel within a hot cell. Because of the variety of activities which can occur in the hot cells, specific details of the accident were not postulated. The mechanical damage would breach the pin cladding and immediately release the gaseous fission products in the fuel-cladding gap. The subsequent fire would cause total reaction of reactive fuel forms. Fission products would be released from the irradiated fuel through the ventilation system which includes HEPA and activated charcoal filtration. The cell inventory and the fraction of the inventory released is shown in Table 8-3. The calculated individual receptor doses at $100 \mathrm{~m}(330 \mathrm{ft})$ and $549 \mathrm{~m}(1,800 \mathrm{ft})$ are as follows:

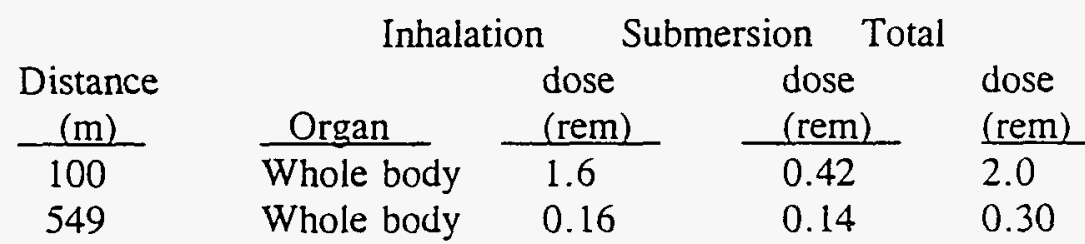

\subsubsection{Non-Radiological Airborne Releases}

None were evaluated in the SAR. 
Table 8-3. 327 Building Radionuclide Inventory and Release Fraction.

\begin{tabular}{|c|c|c|c|c|c|}
\hline Specie & $\begin{array}{l}\text { Source inventory } \\
\text { (Ci) }\end{array}$ & Specie & $\begin{array}{l}\text { Source inventory } \\
\text { (Ci) }\end{array}$ & Specie & $\begin{array}{l}\text { Source inventory } \\
\text { (Ci) }\end{array}$ \\
\hline \multicolumn{6}{|c|}{ Halogens: Release Fraction 0.005} \\
\hline${ }^{129} I$ & $3.16 \mathrm{E}-03$ & & & & \\
\hline \multicolumn{6}{|c|}{ Noble Gases: Release Fraction 1} \\
\hline${ }^{85} \mathrm{Kr}$ & $4.63 \mathrm{E}+02$ & ${ }^{131} \mathrm{mXe}$ & $6.25 E+02$ & ${ }^{133} \mathrm{mXe}$ & $8.55 \mathrm{E}+00$ \\
\hline${ }^{133 \mathrm{Xe}}$ & $1.03 \mathrm{E}+04$ & & & & \\
\hline \multicolumn{6}{|c|}{ Volatile Solids: Release Fraction 2.5 E-04 } \\
\hline${ }^{79} \mathrm{Se}$ & 2.17 E-02 & ${ }^{87} \mathrm{Rb}$ & $9.15 \mathrm{E}-07$ & ${ }^{113} \mathrm{mCd}$ & $9.02 \mathrm{E}+00$ \\
\hline${ }^{115} \mathrm{mCd}$ & $9.96 \mathrm{E}-06$ & ${ }^{134} \mathrm{Cs}$ & $1.37 \mathrm{E}+03^{\circ}$ & ${ }^{135} \mathrm{Cs}$ & $1.17 \mathrm{E}-01$ \\
\hline${ }^{137} \mathrm{Cs}$ & $7.27 \mathrm{E}+03$ & & & & \\
\hline \multicolumn{6}{|c|}{ Nonvolatile Solids: Release Fraction 5.0 E-06 } \\
\hline${ }^{89} \mathrm{Sr}$ & $4.41 \mathrm{E}-02$ & ${ }^{90} \mathrm{Sr}$ & $2.74 \mathrm{E}+03$ & ${ }^{9)} \mathrm{Y}$ & $2.74 \mathrm{E}+03$ \\
\hline${ }^{91} \mathrm{Y}$ & $3.03 \mathrm{E}-01$ & ${ }^{93} \mathrm{Zr}$ & $1.52 \mathrm{E}-01$ & ${ }^{95} \mathrm{Zr}$ & $2.11 \mathrm{E}+00$ \\
\hline${ }^{95} \mathrm{mNb}$ & $2.68 \mathrm{E}-02$ & ${ }^{95} \mathrm{Nb}$ & $4.55 \mathrm{E}+00$ & ${ }^{1103} \mathrm{Ru}$ & $1.72 \mathrm{E}-03$ \\
\hline${ }^{106} \mathrm{Ru}$ & $1.34 \mathrm{E}+04$ & ${ }^{103} \mathrm{mRh}$ & $1.72 \mathrm{E}-03$ & ${ }^{1116} \mathrm{Rh}$ & $1.34 \mathrm{E}+04$ \\
\hline${ }^{107} \mathrm{Pd}$ & $1.60 \mathrm{E}-02$ & ${ }^{110} \mathrm{Ag}$ & $1.94 \mathrm{E}+02$ & ${ }^{114} \mathrm{mIn}$ & $2.82 \mathrm{E}-08$ \\
\hline${ }^{114} \mathrm{In}$ & $2.72 \mathrm{E}-08$ & ${ }^{119} \mathrm{mSn}$ & $2.58 \mathrm{E}+00$ & ${ }^{121} \mathrm{mSn}$ & $9.13 \mathrm{E}-02$ \\
\hline${ }^{123} \mathrm{Sn}$ & $6.13 E+00$ & ${ }^{126} \mathrm{Sn}$ & $9.3 \mathrm{E}-03$ & ${ }^{124} \mathrm{Sb}$ & $5.96 E-04$ \\
\hline${ }^{125} \mathrm{Sb}$ & $9.51 E+02$ & ${ }^{126} \mathrm{mSb}$ & $9.30 \mathrm{E}-03$ & ${ }^{126} \mathrm{Sb}$ & $1.30 \mathrm{E}-03$ \\
\hline${ }^{123} \mathrm{mTe}$ & $2.29 \mathrm{E}-03$ & ${ }^{125} \mathrm{mTe}$ & $2.32 \mathrm{E}+02$ & ${ }^{127} \mathrm{mTe}$ & $3.31 \mathrm{E}+00$ \\
\hline${ }^{127} \mathrm{Te}$ & $3.24 \mathrm{E}+00$ & ${ }^{129} \mathrm{mTe}$ & $2.55 \mathrm{E}-06$ & ${ }^{129} \mathrm{Te}$ & 1.62 E-06 \\
\hline${ }^{137} \mathrm{mBa}$ & $6.88 \mathrm{E}+03$ & ${ }^{141} \mathrm{Ce}$ & $2.23 \mathrm{E}-05$ & ${ }^{1+4} \mathrm{Ce}$ & $7.36 \mathrm{E}+03$ \\
\hline${ }^{144} \mathrm{Pr}$ & $7.36 \mathrm{E}+03$ & ${ }^{147} \mathrm{Pm}$ & $1.11 \mathrm{E}+04$ & ${ }^{148} \mathrm{mPm}$ & $6.21 \mathrm{E}-05$ \\
\hline${ }^{148} \mathrm{Pm}$ & $4.28 \mathrm{E}-06$ & ${ }^{151} \mathrm{Sm}$ & $3.04 E+02$ & ${ }^{152} \mathrm{Eu}$ & $1.05 E+00$ \\
\hline${ }^{154} \mathrm{Eu}$ & $1.35 E+02$ & ${ }^{155} \mathrm{Eu}$ & $8.83 \mathrm{E}+02$ & ${ }^{153} \mathrm{Gd}$ & $1.24 \mathrm{E}-02$ \\
\hline${ }^{160} \mathrm{~Tb}$ & $8.24 \mathrm{E}-03$ & ${ }^{166} \mathrm{mHo}$ & $1.52 \mathrm{E}-03$ & & \\
\hline \multicolumn{6}{|c|}{ Heavy Metals: Release Fraction 5.0 E-06 } \\
\hline${ }^{239} \mathrm{Pu}$ & $2.24 \mathrm{E}+00$ & ${ }^{240} \mathrm{Pu}$ & $2.21 E+00$ & ${ }^{241} \mathrm{Pu}$ & $3.46 E+02$ \\
\hline
\end{tabular}


WHC-SD-SNF-TI-002, Rev. 0

\subsubsection{Radiological Liquid Releases}

No accidents have been postulated in the 327 Building SAR (HEDL 1985) which result in storage pool failure or other liquid releases. The storage pool has not been seismically analyzed. The water quality of the 327 facility storage pool, which is analyzed quarterly, is listed in Table 8-4.

Table 8-4. 327 Building Storage Pool Water Quality.

\begin{tabular}{|l|c|c|c|}
\hline \multicolumn{1}{|c|}{ Isotope } & $\begin{array}{c}\text { 1st quarter } \\
1993 \text { data } \\
\text { (pCi/g) }\end{array}$ & $\begin{array}{c}\text { 2nd quarter } \\
1993 \text { data } \\
\text { (Pci/g) }\end{array}$ & $\begin{array}{c}\text { 3rd quarter } \\
\text { 1993 data } \\
\text { (Pci/g) }\end{array}$ \\
\hline${ }^{54} \mathrm{Mn}$ & 0.14 & -- & 0.026 \\
\hline${ }^{134} \mathrm{Cs}$ & .05 & -- & 0.027 \\
\hline${ }^{137} \mathrm{Cs}$ & 2.39 & 2.21 & 3.22 \\
\hline${ }^{60} \mathrm{Co}$ & 0.98 & 0.38 & 0.90 \\
\hline
\end{tabular}

\subsubsection{Non-Radiological Liquid Releases}

None were evaluated in the SAR. 
WHC-SD-SNF-TI-002, Rev. 0

\subsection{BULLDING}

\subsection{GENERAL INFORMATION}

The 308 Building, located in the 300 Area of the Hanford Site, is a two-story structure constructed of reinforced concrete, concrete block, and steel siding, with the interior finished in painted plaster. The interior support columns are reinforced concrete. The floors are reinforced concrete with a painted or vinyl surface. The roofs are constructed with a steel decking covered with insulating concrete and topped with a built-up tar and gravel coating. The interior of the building consists of office space, laboratory facilities, gloveboxes, fuel element assembly and storage areas, X-ray facilities, the Neutron Radiography Facility (NRF), and maintenance areas. The 308 Building and NRF are shown schematically in Figures 9-1 through 9-4.

The building was designed as a multipurpose nuclear facility for the development and fabrication of nuclear reactor fuels containing plutonium. Originally constructed in 1961, the building has been expanded several times to reach the current $6,600 \mathrm{~m}^{2}\left(71,000 \mathrm{ft}^{2}\right)$ of floor space. Of this area, the first floor laboratories comprise $2,249 \mathrm{~m}^{2}\left(24,000 \mathrm{ft}^{2}\right)$; second floor laboratories and personnel corridor comprise $950 \mathrm{~m}^{2}\left(10,000 \mathrm{ft}^{2}\right)$; the maintenance shops. service areas, and ventilation equipment comprise $1,480 \mathrm{~m}^{2}\left(16,000 \mathrm{ft}^{2}\right)$; the 308 Annex comprises $870 \mathrm{~m}^{2}\left(9,400 \mathrm{ft}^{2}\right)$; and an attached office building comprises $1,050 \mathrm{~m}^{2}$ $\left(11,300 \mathrm{ft}^{2}\right)$.

A large fuel assembly area was added in 1970 . Over 2,000 fuel configurations were produced in the 308 Building before 1976, many for a variety of offsite reactors. Between 1975 and 1979, the 308 Building was expanded with the addition of the 308 Annex and the Test, Research, Isotope, General Atomics (TRIGA) reactor. From 1976 until 1992, the main mission of the 308 Building was preparation and quality assurance verification and testing of all FFTF fuel assemblies.

Because the 308 Building is a plutonium facility (FFTF fuel manufacture) in close proximity to the City of Richland, and with the shutdown of the FFTF reactor, the facility no longer has a fuel production mission. Maintaining the safety envelope for the facility is too costly with no identified mission. Therefore, the main process building and the office wing were deactivated on March 31,1994. The annex remains as a storage facility for the TRIGA fuel.

The NRF consists of that portion of the 308 Building Annex which houses the TRIGA reactor and associated neutron radiography equipment. The NRF consists of the reactor hall, control room, and irradiated fuel cask handling room. The main feature of the facility is the TRIGA Mark I reactor, which is housed in a cylindrical reinforced-concrete, aluminum-lined water pool, $2.8 \mathrm{~m}(9.2 \mathrm{ft})$ in diameter and $6 \mathrm{~m}(20 \mathrm{ft})$ deep. Although connected to the 
Figure 9-1. 308 Building Floor Plan.

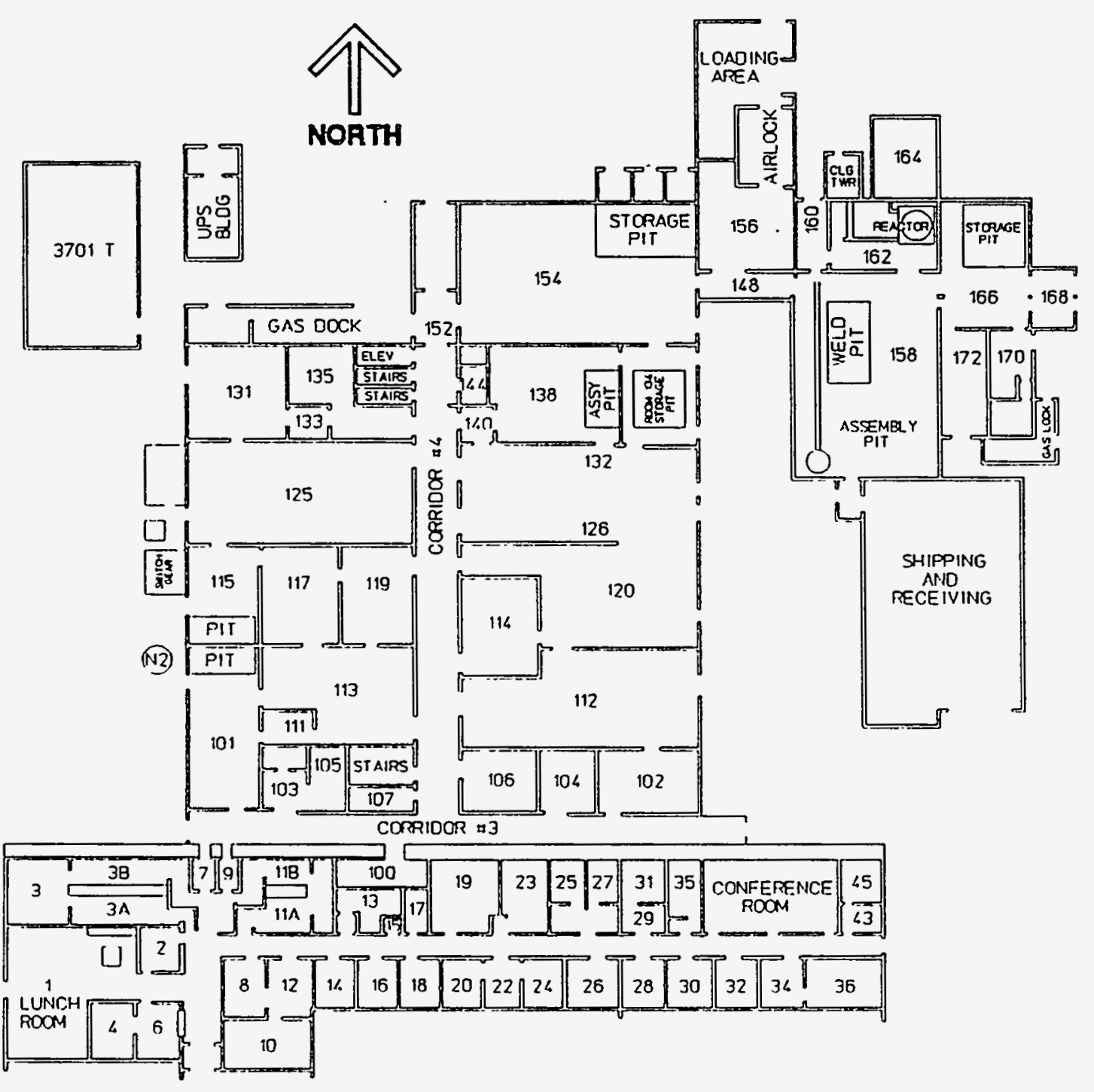


Figure 9-2. Neutron Radiography Facility and TRIGA Reactor (308 Building).

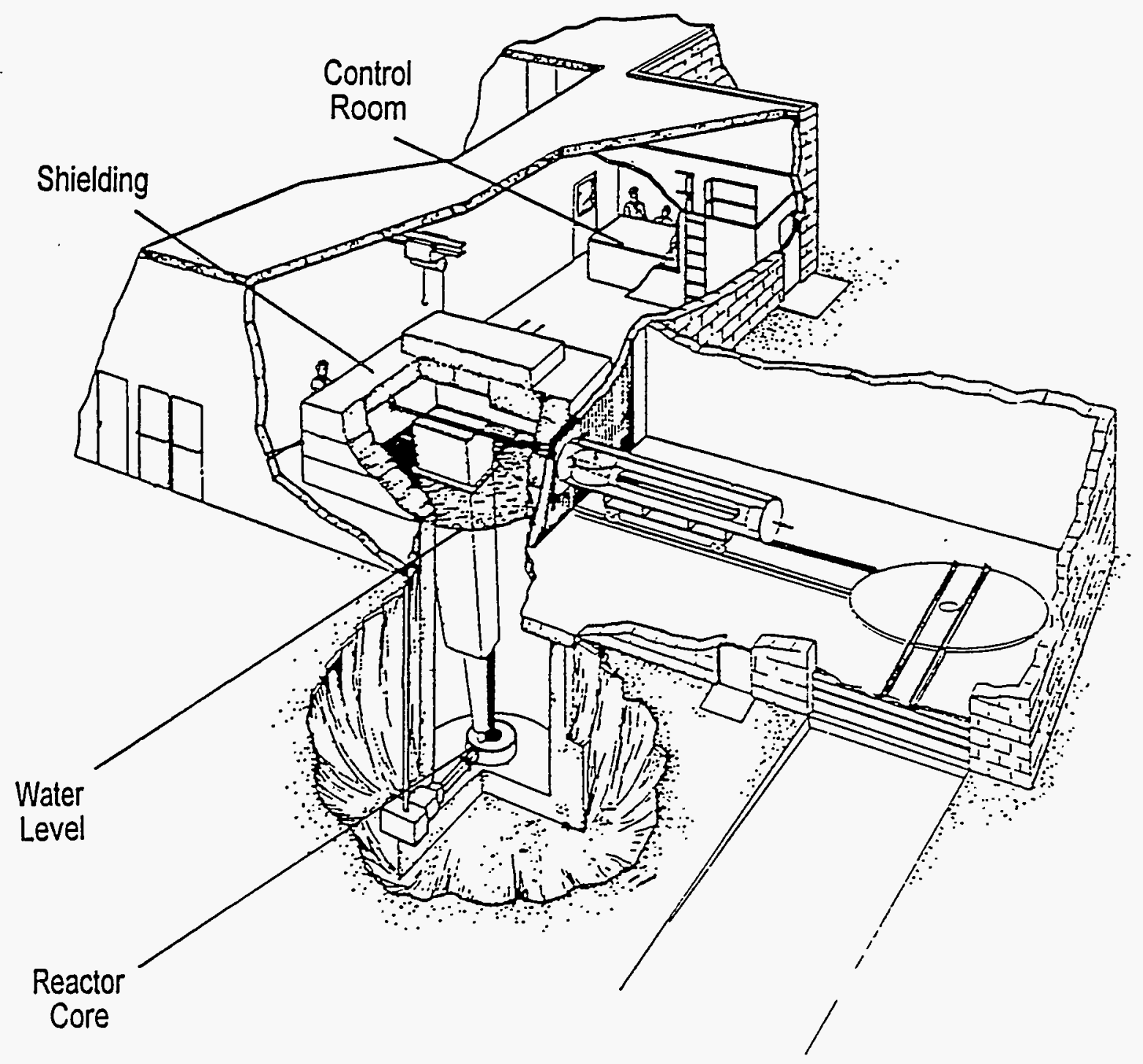


Figure 9-3. NRF TRIGA Core (308 Building).

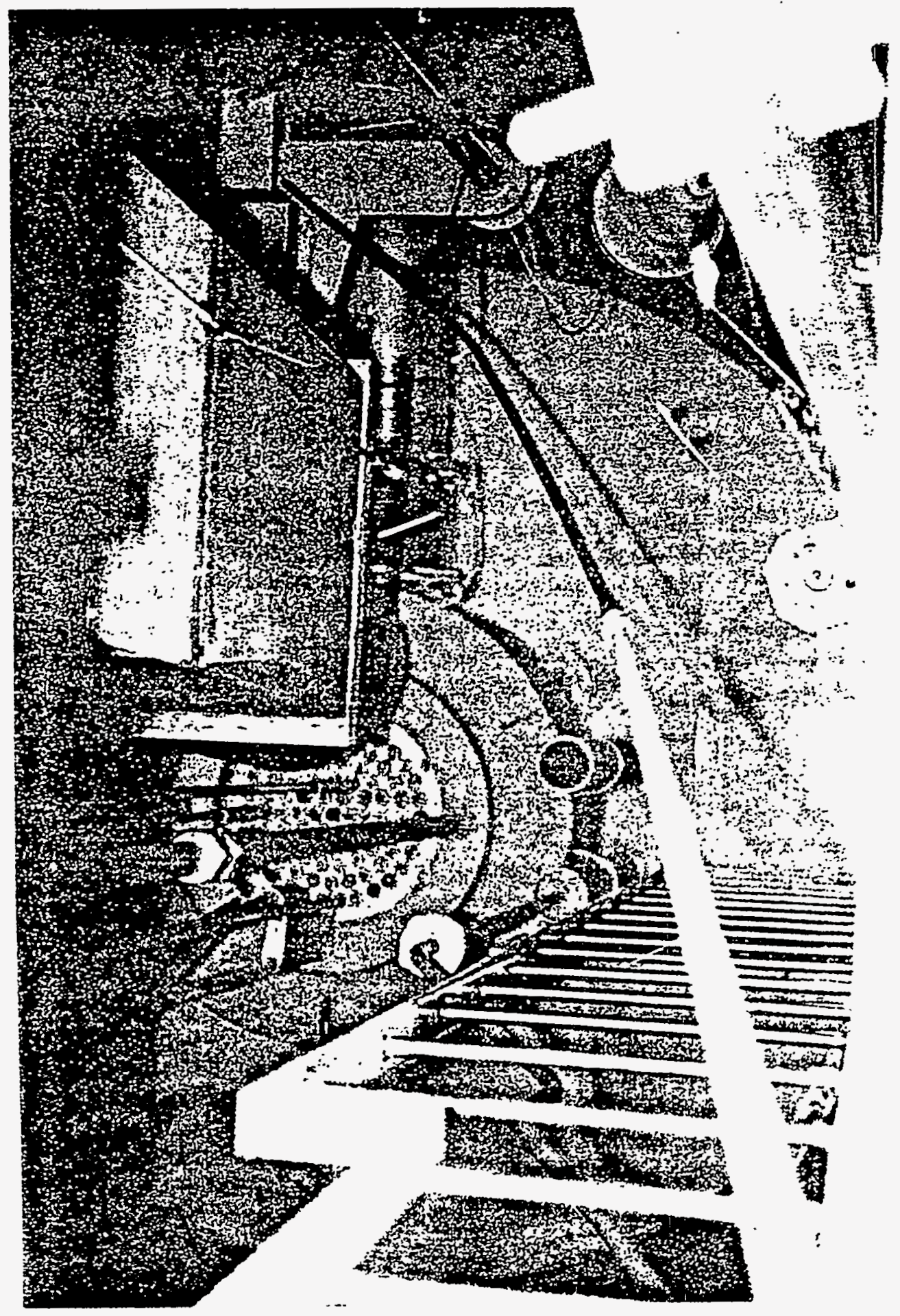




\section{WHC-SD-SNF-TI-002, Rev. 0}

Figure 9-4. NRF TRIGA Core Map and Storage Locations (308 Building).

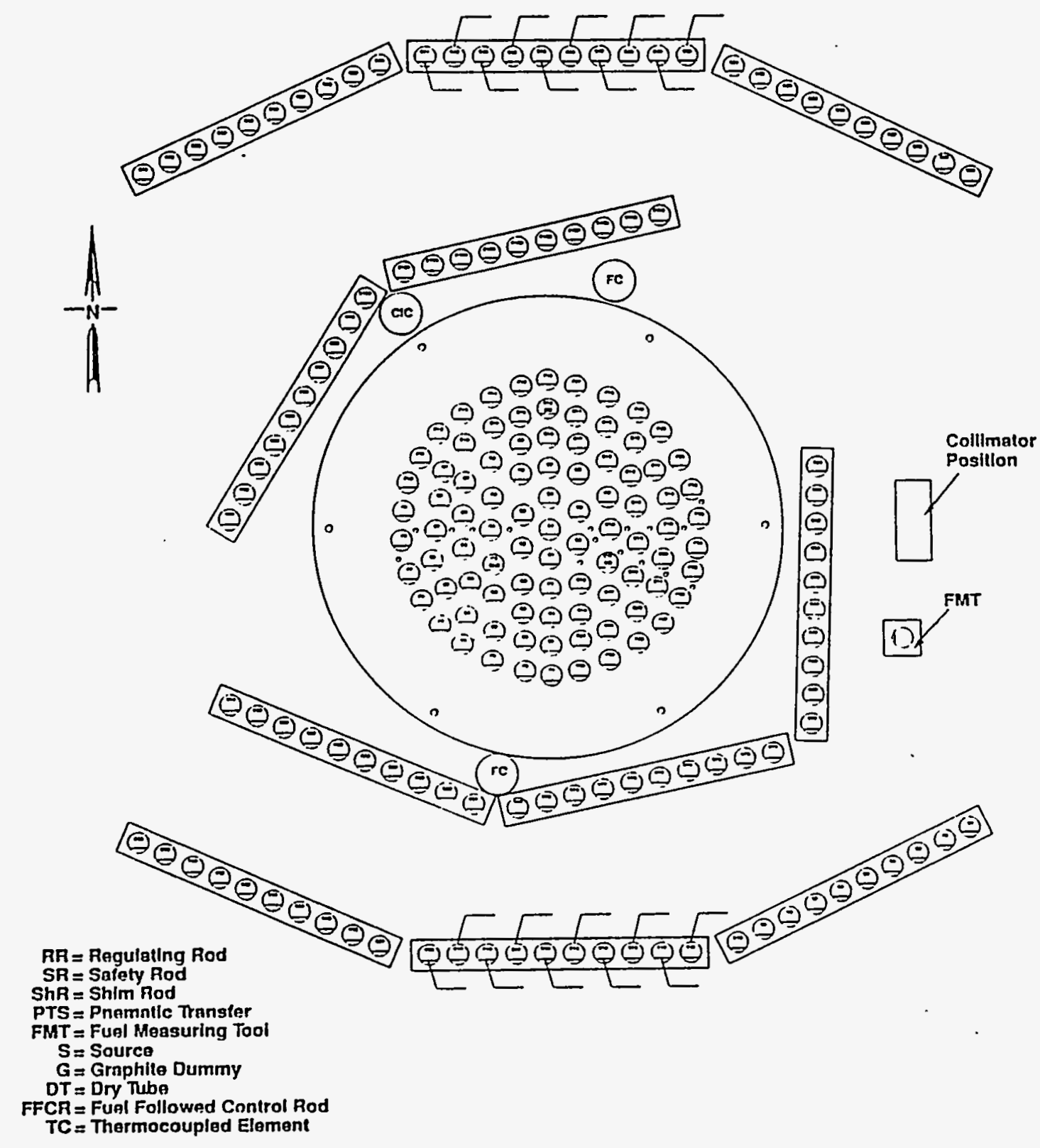


308 Building by a 7.6-m- (25-ft-) long airlock, the building and annex do not share a common wall. The annex walls are constructed of steel-reinforced-concrete block, and the roof is a weather-sealed steel deck.

The TRIGA reactor in the NRF was used primarily as a source of neutrons for the NRF to generate radiographs of fabricated fuel pins. It was used to a lesser extent in neutron activation analysis and as a training platform for other reactors. The TRIGA reactor was installed in the NRF in the late 1970's and operated intermittently for 13 years. Currently, there are no plans to use the 308 Building or the NRF for nuclear fuel development or fabrication. The facility is being placed in long term shutdown configuration and the NRF is no longer needed. The TRIGA reactor has been shut down since May 1989.

\subsection{IRRADIATED TRIGA FUEL STORAGE AT THE 308 BUILDING}

The final disposition of the 104 TRIGA fuel elements (101 have been irradiated) has not been determined. In the interim, the fuel elements are being stored in subcritical racks around the periphery of the reactor pool. Following the transfer of all fuel elements from the reactor core to the storage racks, the status of the reactor was changed to that of a fuel storage basin in accordance with the DOE-approved shutdown plan for the TRIGA reactor. The reactor pool is now referred to as the TRIGA fuel storage basin.

With the shutdown of the 308 Building, current planning calls for the removal of the fuel from the TRIGA fuel storage basin and dry storage of the fuel in casks at either the 200 West Area Central Waste Complex, or on a storage pad with the FFTF fuel in the 400 Area.

\subsection{TRANSPORTATION}

Although there are rail spurs in the 300 Area, no direct rail access to the 308 facility is available. Any movement of materials to or from the facility would need to be done by truck. The 308 Building TRIGA fuel storage basin room has an overhead crane with a 4.5-metric ton (5-ton) capacity, which could be used to move the fuel inside the building. Numerous other cranes exist in the 308 Building adjacent to the TRIGA fuel storage basin which could also be used, if required, for fuel movement. 


\subsection{ESTIMATED STAFF SIZE AND OPERATIONAL COST}

\subsubsection{Estimated Staff Size}

As of October 1, 1994 the staff size at the 308 Building is 12.5 full time staff equivalents. The fractional number results from staff who split time between more than one facility. Of the 12.5 full time staff equivalents, 3.4 are directly involved in surveillance and maintenance of the NRF and TRIGA fuel. Both the 12.5 and the 3.4 full time staff equivalents are operators, craftspersons, health physics technicians, engineers, and supervisors. Any movement of fuel will require additional staff.

\subsubsection{Estimated Operational Cost ${ }^{1}$}

The total operational cost for the 308 Building is approximately $\$ 1.2$ million/year. Approximately $\$ 750,000$ of the total is for surveillance and maintenance of the NRF and TRIGA fuel.

\subsection{ESTIMATED OPERATIONAL DOSE COMMITMENT}

The low irradiation of the fuel and the shielding provided by the water in the reactor vessel has resulted in the dose being very low (less than 0.5 man-rem per year associated with storage of the fuel).

\subsection{ESTIMATED ROUTINE ENVIRONMENTAL RELEASES}

The estimated environmental releases have been divided into four categories as follows:

- Radiological airborne emissions

- Nonradiological airborne emissions

- Radiological liquid effluents

- Nonradiological liquid effluents.

\subsubsection{Radiological Airborne Emissions}

Environmental releases from the operation of the NRF for calendar years 1990, 1991, . and 1992 are presented in Table 9-1. This stack discharges filtered air from the reactor hall housing the TRIGA reactor. The reactor is permanently shut down and the fuel has been

\footnotetext{
'Information obtained from Operations.
} 
WHC-SD-SNF-TI-002, Rev. 0

Table 9-1. 308 Building Airborne TRIGA Storage Basin Radionuclide Releases.

\begin{tabular}{|l|c|c|c|}
\hline \multicolumn{1}{|c|}{ Radionuclide } & $\begin{array}{c}1992 \text { totals (Ci) } \\
\text { (DOE-RL 1993b) }\end{array}$ & $\begin{array}{c}1991 \text { totals (Ci) } \\
\text { (DOE-RL 1992) }\end{array}$ & $\begin{array}{c}1990 \text { totals (Ci) } \\
\text { (DOE-RL 1991) }\end{array}$ \\
\hline${ }^{90} \mathrm{Sr}$ & Not measured & Not measured & 1.0 E-07 \\
\hline${ }^{239} \mathrm{Pu}^{\mathrm{a}}$ & Not measured & $4.0 \mathrm{E}-08$ & $3.9 \mathrm{E}-08$ \\
\hline Total alpha & $3.0 \mathrm{E}-08$ & Not available & Not available \\
\hline Total beta ${ }^{\mathrm{b}}$ & $1.1 \mathrm{E}-07$ & Not available & Not available \\
\hline Total flow & $3.0 \mathrm{E}+07 \mathrm{~m}^{3}$ & $4.5 \mathrm{E}+07 \mathrm{~m}^{3}$ & Not available \\
\hline
\end{tabular}

${ }^{a}$ The small amount of Pu released from the TRIGA stack was not associated with operation of the reactor.

${ }^{\mathrm{b}}$ Total alpha and total beta counts are for particulate only.

downloaded to fuel storage racks within the pool. During facility operation, releases from the TRIGA fuel were negligible as compared with other sources in the 308 Building. Emission monitoring in the past consisted of a record sampler and an alpha continuous air monitor.

An interim safety basis (WHC 1994d) has been approved for the 308 Building (including the TRIGA fuel storage basin) and all continuous air monitors and stack monitoring have been discontinued and taken out of service. Before the monitoring systems could be removed from service, all of the sources in the building were either removed or isolated.

\subsubsection{Non-Radiological Airborne Emissions}

There is no routine monitoring of nonradioactive releases for the 308 Building. Any releases which might occur have not been considered to be significant, and therefore no constituents are measured.

\subsubsection{Building Stack Information (DOE-RL 1993b and WHC 1993d)}

Stack Height: $11.3 \mathrm{~m}(37 \mathrm{ft})$

Flow rate': 57,000 to $71,000 \mathrm{~L} / \mathrm{min}\left(2,010\right.$ to $\left.2,508 \mathrm{ft}^{3} / \mathrm{min}\right)$; usually $57,000 \mathrm{~L} / \mathrm{min}$ Diameter: $31 \mathrm{~cm}$ (12 in.)

Temperature: 18 to $26 \circ \mathrm{C}(65 \cdot$ to $78 \circ \mathrm{F})$; usually $22 \circ \mathrm{C}(72 \circ \mathrm{F})$.

\footnotetext{
'These flow rates represent an operating facility. Since shutdown the tlow rates have been lowered to approximately $45,000 \mathrm{~L} / \mathrm{min}\left(1,600 \mathrm{ft}^{3} / \mathrm{min}\right)$.
} 
WHC-SD-SNF-TI-002, Rev. 0

\subsubsection{Radiological and Non-Radiological Liquid Effluents}

There are no routine liquid effluent streams resulting from irradiated fuel storage at the 308 Building.

\subsection{BOUNDING ACCIDENT SCENARIO AND RELATED ENVIRONMENTAL RELEASES}

\subsubsection{Radiological Airborne Releases}

The bounding accident for airborne releases related to irradiated fuel storage is the dropping of the transfer basket while removing fuel from the storage pool to the shipping/storage cask (WHC 1994d). It was conservatively estimated that 15 elements would have their cladding damaged, resulting in the release of 100 percent of the ${ }^{85} \mathrm{Kr}$, approximately $2.6 \mathrm{Ci}$, to the environment. The resulting dose was estimated at $12.9 \mathrm{mrem}$ to the worker, $0.86 \mathrm{mrem}$ to the onsite individual, and $0.086 \mathrm{mrem}$ at the site boundary.

\subsubsection{Non-Radiological Airborne Releases}

None were identified in the interim safety basis (WHC 1994d) or safety assessment document (WHC 1993c).

\subsubsection{Radiological Liquid Releases}

A total loss of pool water accident was evaluated in the SAR (WHC 1990) and referenced in the interim safety basis (WHC 1994d). No onsite or offsite consequences were found because of the lack of contamination in the TRIGA fuel storage basin.

The water quality of the TRIGA fuel storage basin is analyzed monthly. Results for three months in 1994, shown in Table 9-2, are below detection limits for nearly all nuclides tested. The TRIGA fuel storage basin has never contained a breached fuel element.

Additional analysis has indicated that the $\mathrm{Ph}$ of the storage pool has ranged between 7.0 and 8.0 , with a conductivity ranging between 0.1 and $4.5 \mu \mathrm{mho} / \mathrm{cm}$.

\subsubsection{Non-Radiological Liquid Releases}

No nonradiological liquid releases were identified in the interim safery basis (WHC 1994d) or SAR (WHC 1990). 
WHC-SD-SNF-TI-002, Rev. 0

Table 9-2. 308 Building TRIGA Fuel Storage

Basin Analysis.

\begin{tabular}{|l|l|l|l|}
\hline Isotope & $\begin{array}{c}\text { April 1994 } \\
\text { data } \\
(\mathrm{pCi} / \mathrm{ml})\end{array}$ & $\begin{array}{c}\text { May 1994 } \\
\text { data } \\
(\mathrm{pCi} / \mathrm{ml})\end{array}$ & $\begin{array}{c}\text { June 1994 } \\
\text { data } \\
(\mathrm{pCi} / \mathrm{ml})\end{array}$ \\
\hline${ }^{40} \mathrm{~K}$ & $<13.1$ & $<1.48$ & $<4.9$ \\
\hline${ }^{54} \mathrm{Mn}$ & $<0.33$ & $<0.035$ & $<0.4$ \\
\hline${ }^{60} \mathrm{Co}$ & $<0.36$ & 0.0882 & $<0.6$ \\
\hline${ }^{137} \mathrm{Cs}$ & 10.8 & $<0.012$ & $<2.0$ \\
\hline${ }^{154} \mathrm{Eu}$ & $<1.05$ & $<.105$ & $<1.1$ \\
\hline${ }^{241} \mathrm{Am}$ & $<0.69$ & $<0.207$ & $<0.6$ \\
\hline
\end{tabular}




\subsection{WEST AREA BURIAL GROUNDS REACTOR IRRADIATED NUCLEAR MATERIALS STORAGE FACILITIES}

\subsection{GENERAL INFORMATION}

Located in the 200 Area of the Hanford reservation, the 200 West Area burial ground provides for disposal and retrievable storage of solid waste. This includes retrievable storage of materials identified by the DOE Headquarters-appointed Spent Fuel Working Group as "Reactor Irradiated Nuclear Materials (RINM)". The Spent Fuel Working Group defined RINM as "... spent nuclear fuel (in any condition) and irradiated nuclear targets from production and research reactors. These materials have been withdrawn from nuclear reactors following irradiation or; in a few cases, still reside within inactive reactors. Their constituent elements have not been separated by processing." (Spent Fuel Working Group Report on Inventory and Storage of the Department's Spent Nuclear Fuel and Other Reactor Irradiated Nuclear Materials and their Environmental, Safety, and Health Vulnerabilities [DOE 1993]).

The RINM stored in the burial ground are retrievably stored in casks and containers. These materials were received into the burial ground as, and are currently managed as contact-handled and remote-handled TRU waste. The categorization of these materials as RINM, spent fuel, or TRU has been identified as a potential vulnerability by the Spent Fuel Working Group. Actions are underway to resolve the vulnerability, resolution is still pending. For the purpose of consistency with the Spent Fuel Working Group's assessment, these materials will continue to be referred to as RINM. Of the six burial grounds within the 200 West Area, covering a total of approximately 117 hectares (289 acres), two burial grounds (see Figures 10.1 and 10.2) are used for storage of RINM. Burial Ground 218-W$3 \mathrm{~A}$, which began receiving waste in 1970, consists of 61 trenches covering approximately 20 hectares ( 50 acres). Burial Ground $218-\mathrm{W}-4 \mathrm{C}$, which began receiving waste in 1978, consists of 69 trenches covering approximately 21 hectares $(52$ acres). The two burial grounds utilized two basic types of trenches for storage of RINM, V trenches and below grade asphalt pads.

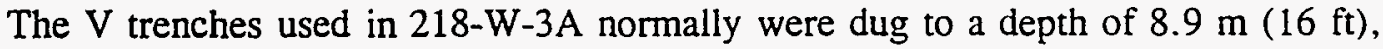
with the bottom ranging from 0 to $8.9 \mathrm{~m}$ (0 to $16 \mathrm{ft}$ ) wide. Trench slopes ranged from $1 \mathrm{H}: 1 \mathrm{~V}$ to $1.5 \mathrm{H}: 1 \mathrm{~V}$ (where $\mathrm{H}=$ horizontal and $\mathrm{V}=$ vertical). RINM was placed in storage modules within two $\mathrm{V}$ trenches, and the trenches were backfilled with a minimum of $1.2 \mathrm{~m}$ $(4 \mathrm{ft})$ of soil. Storage trenches constructed in the $218-\mathrm{W}-4 \mathrm{C}$ burial ground were built with asphalt working surfaces. The $218-\mathrm{W}-4 \mathrm{C}$ trenches are approximately $182.8 \mathrm{~m}(600 \mathrm{ft})$ long, $7.6 \mathrm{~m}(25 \mathrm{ft})$ wide and about $1.8 \mathrm{~m}(6 \mathrm{ft})$ below grade. This depth varies from the front to the rear of the trench. Most containers were stacked into modules, typically 12 drums wide, 
WHC-SD-SNF-TI-002, Rev. 0

Figure 10-1. Burial Ground 218-W-3A.

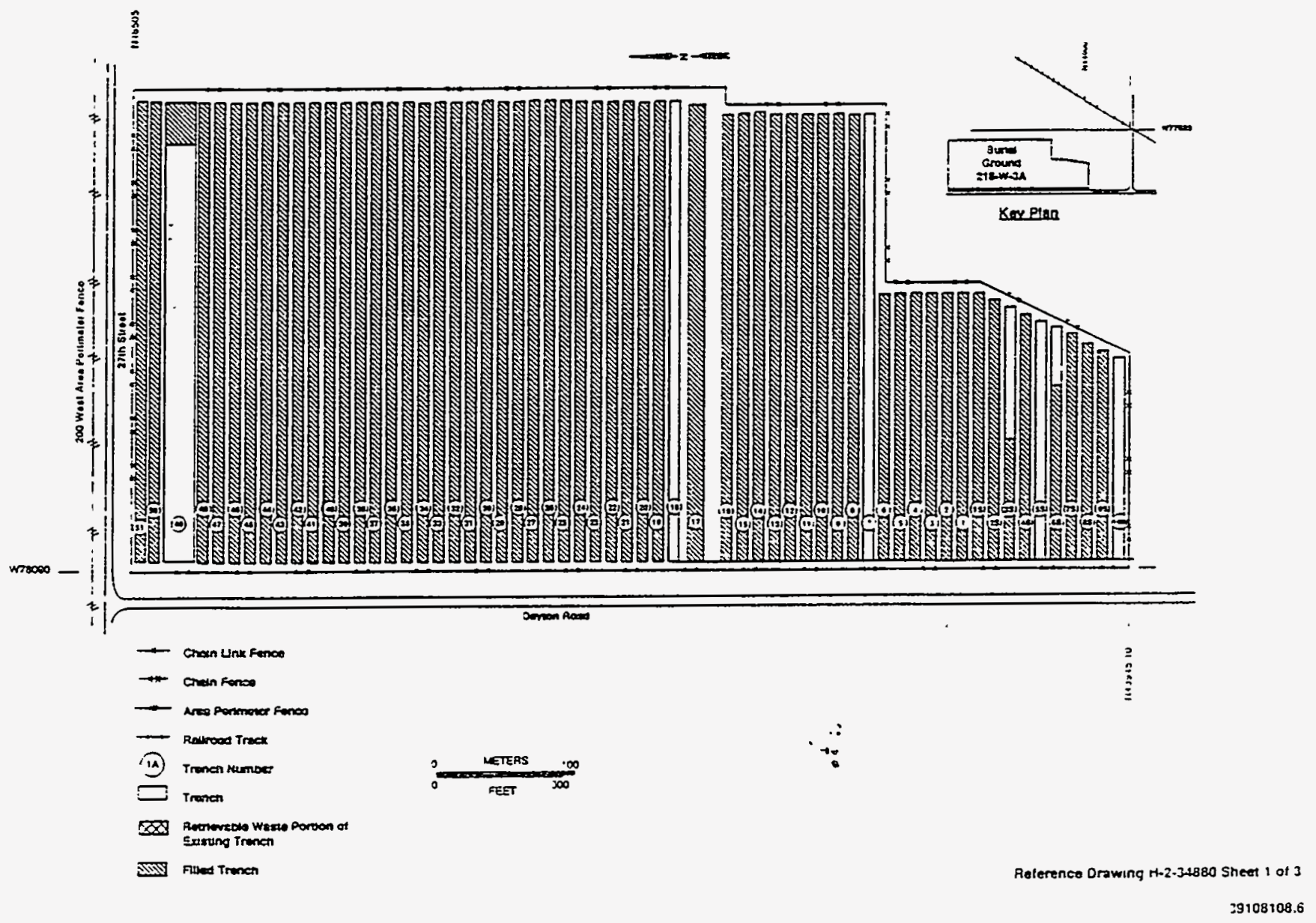


Figure 10-2. Burial Ground 218-W-4C.

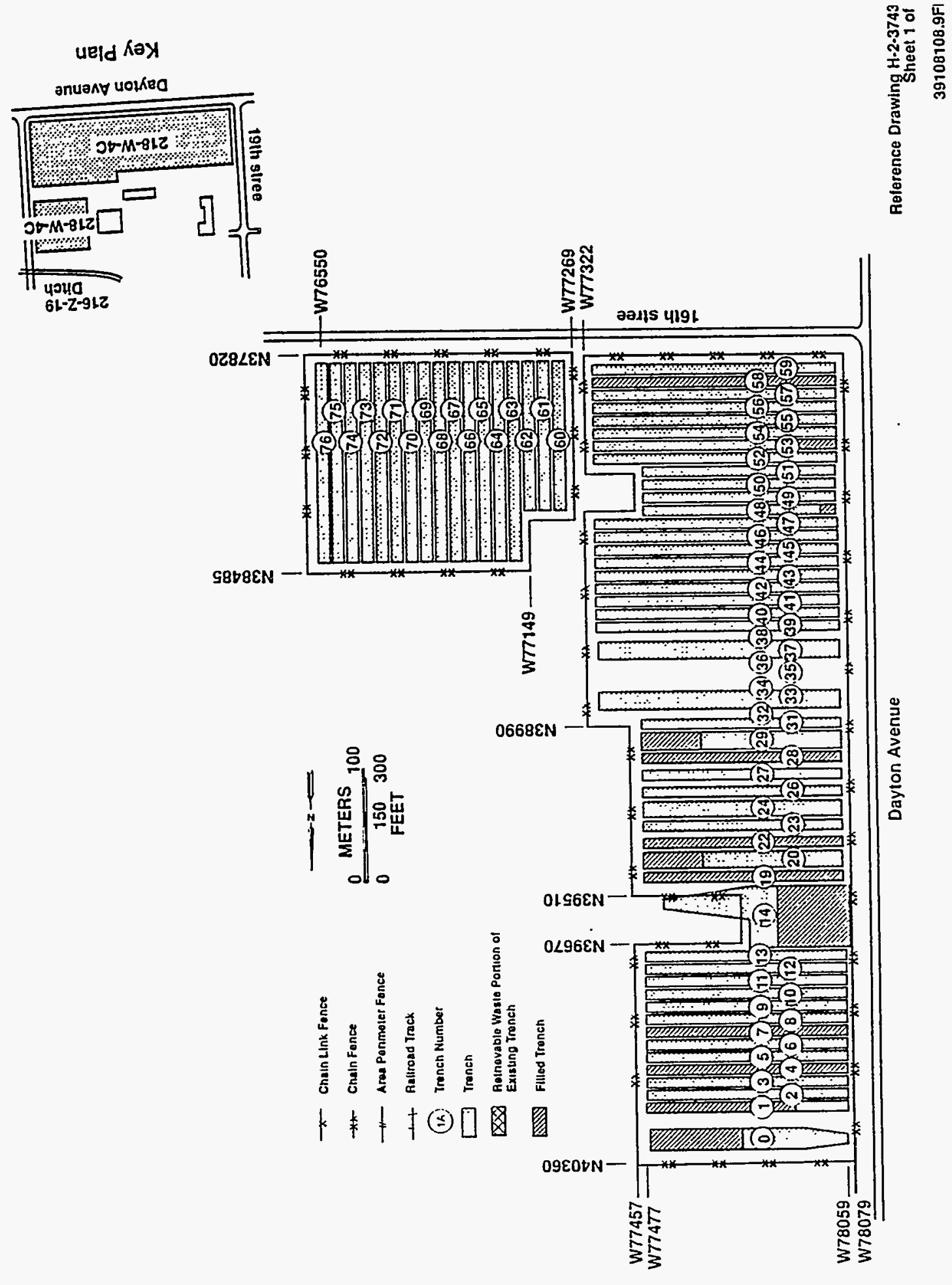

10-3 
WHC-SD-SNF-TI-002, Rev. 0

Figure 10-3. EBR-II Cask.

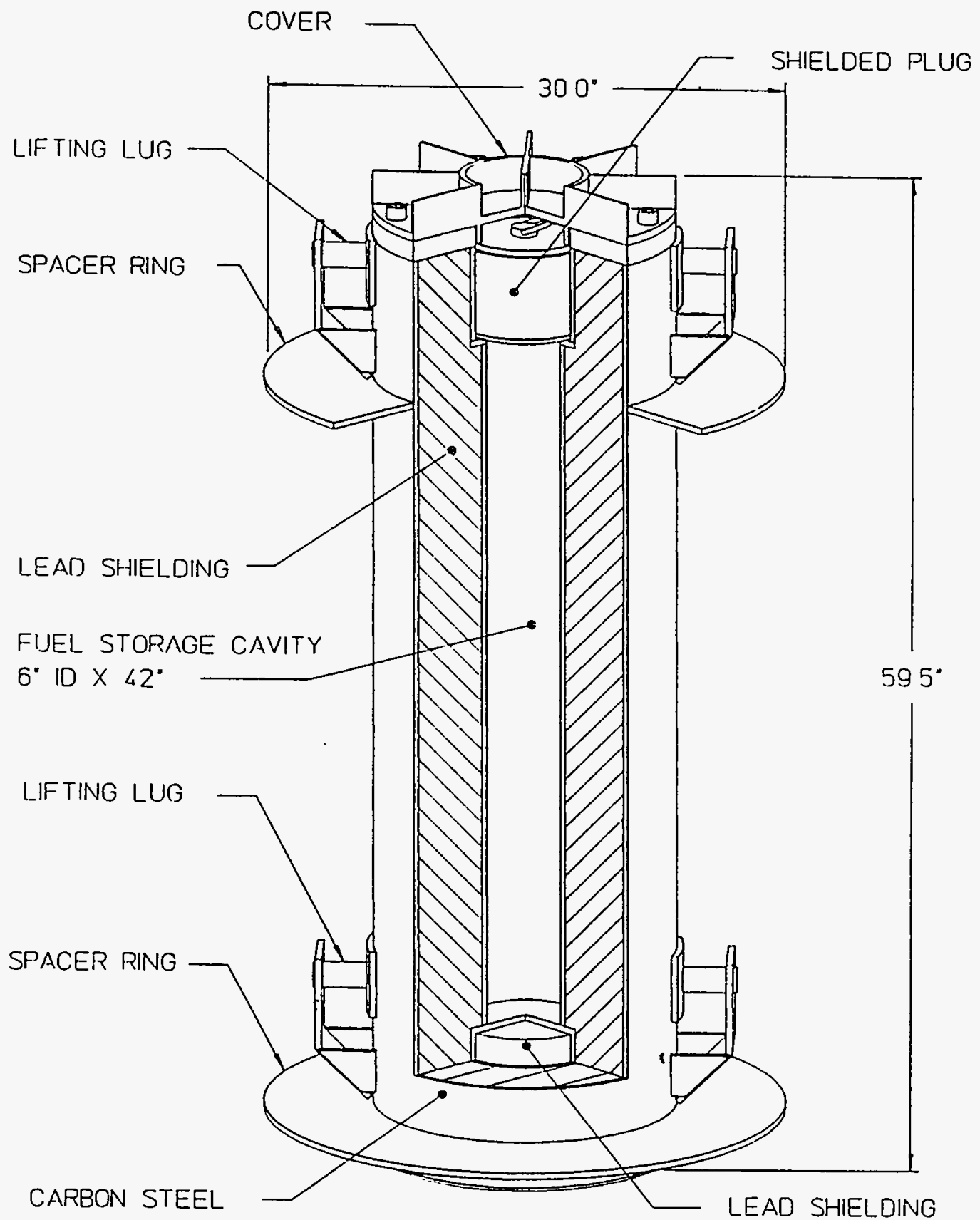


12 drums deep, and 4 drums high. The waste packages were then covered with plywood and

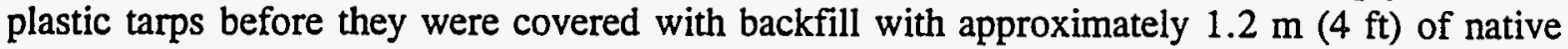
materials. This general storage configuration was used for drummed RINM.

Backfilling of RINM was suspended in the late 1980's, and EBR-II containers (see Figure 10-3) placed in 218-W-4C, trench number one, are stored exposed to the elements. The RINM waste containers are located in separate storage modules within the individual trenches. The RINM containers also are segregated from non-RINM containers. Burial ground operations has suspended the receipt of RINM for storage. However, efforts are being negotiated with the State to continue this dry storage mode of operation.

\subsection{RINM STORED AS REMOTE-HANDLED TRU WASTE IN THE 200 WEST AREA BURIAL GROUNDS}

Since $1974, .75$ containers of experimental RINM have been placed in retrievable storage units within 218-W-3A and 218-W-4C low-level burial grounds in compliance with the applicable DOE regulations and normal operating practices. These materials are managed as remote-handled TRU waste. Burial ground $218-\mathrm{W}-3 \mathrm{~A}$, trench 8 , has 22 concrete-shielded casks each holding 4 General Electric waste liners. Trench S6 has 5 EBR-II lead-lined carbon steel casks. Burial ground 218-W-4C, trench 1, contains stored RINM in 34 lead-lined carbon steel EBR-II casks and one zircaloy-hull container similar to the EBR-II cask (there are two zircaloy hull casks in the trench, but only one contains RINM). Thirteen lead-lined concrete-filled 208-L (55-gal) drums of irradiated TRIGA material are stored in trench 7.

\subsection{ESTIMATED STAFF SIZE AND OPERATIONAL COST}

\subsubsection{Estimated Staff Size}

The only routine activity involving the RINM stored containers involves those that are exposed in burial ground $218-\mathrm{W}-4 \mathrm{C}$, trench 1 . This activity involves burial ground staff who perform weekly visual surveillance of the outside of the RINM shielded storage casks. This surveillance activity requires less than 1 hour per week ${ }^{1}$ or approximately $1 / 40$ th of a full time equivalent.

\subsubsection{Estimated Operational Cost}

Based on the staff requirement above, the operational cost is approximately $\$ 4,000 /$ year.

\footnotetext{
'Information obtained from Low-Level Burial Ground Operations.
} 


\subsection{ESTIMATED OPERATIONAL DOSE COMMITMENT}

Exact dose rates have not been calculated; however, all of the RINM is stored in shielded casks and the visual surveillance does not require physical contact with the casks. The dose rate at the surface of the casks is less than $100 \mathrm{mrem} / \mathrm{hour}$.

\subsection{ESTIMATED ENVIRONMENTAL RELEASES} follows:

The estimated environmental releases have been divided into four categories as

- Radiological airborne emissions

- Nonradiological airborne emissions

- Radiological liquid effluents

- Nonradiological liquid effluents.

\subsubsection{Radiological Airborne Emissions}

All of the materials at the 200 West Area burial ground are contained within sealed packagings; therefore, there are no routine emissions from the burial grounds. Air monitors are placed around the burial grounds as a part of the overall air monitoring system in the 200 West Area. Any emissions from the burial grounds would be detected by 200 Area air monitoring activities.

\subsubsection{Non-Radiological Airborne emissions}

There is no routine monitoring of nonradioactive releases from the 200 West Area burial ground. Potential releases have been considered to be insignificant; therefore, no constituents are measured.

\subsubsection{West Area Burial Ground Stack Information}

There are no stacks in the 200 West Area burial ground.

\subsubsection{Radiological Liquid Effluents}

There are no liquid effluent streams resulting from RINM stored at the 200 West Area burial ground. 


\subsubsection{Non-Radiological Liquid Effluents}

There are no liquid effluent streams resulting from RINM stored at the 200 West burial grounds.

\subsection{BOUNDING ACCIDENT SCENARIO AND RELATED ENVIRONMENTAL RELEASES}

The only accident postulated to have any significant radiological releases in the Retrievable Storage of Irradiated Fuels in the Solid Waste Burial Grounds (WHC 1992b) is briefly described as a vehicle impact on one or more EBR-II cask(s) followed by a fire. Two vehicle impact scenarios were evaluated:

1. Severe impact or collision followed by a short-duration fire caused by a vehicular accident in the trench

2. Extremely severe impact or collision followed by a long-duration fire.

The consequences calculated are well within the risk acceptance criteria used by Westinghouse Hanford Company. The consequences were conservatively calculated for an onsite receptor at $100 \mathrm{~m}$ from the accident in the direction of maximum dose consequence. This individual is assumed to remain at this location for the entire duration of the fire and radionuclide release from the accident with a 50-year dose commitment calculated for inhalation. The maximum offsite receptor is located $16 \mathrm{~km}$ east-northeast at the Hanford Site boundary. To. estimate the ingestion and ground-contamination pathways for the total longterm dose, the individual (hypothetical) is assumed to continue residing at this location for 50 years. $10-4$.

The postulated results of these accidents are included in Tables 10-1, 10-2,10-3, and

Table 10-1. Release Fractions for Low-

Level Waste Burial Ground Accident Scenarios.

\begin{tabular}{|l|c|c|}
\hline \multirow{2}{*}{ Material } & \multicolumn{2}{|c|}{ Release fraction } \\
\cline { 2 - 3 } & Scenario 1 & Scenario 2 \\
\hline${ }^{85} \mathrm{Kr}$ gas & $3.3 \times 10^{-2}$ & $3.9 \times 10^{-1}$ \\
\hline Cesium & $2.0 \times 10^{-5}$ & $2.0 \times 10^{-4}$ \\
\hline Ruthenium & $2.7 \times 10^{-6}$ & $4.8 \times 10^{-5}$ \\
\hline Particulates & $2.0 \times 10^{-7}$ & $2.0 \times 10^{-6}$ \\
\hline
\end{tabular}


WHC-SD-SNF-TI-002, Rev. 0

Table 10-2. Low-Level Burial Ground EBR-II Cask Inventories and Release Quantities.

\begin{tabular}{|c|c|c|c|c|c|c|c|c|}
\hline \multirow{2}{*}{\multicolumn{3}{|c|}{ Per-cask inventories (Ci) }} & \multicolumn{3}{|c|}{ Accident Scenario 1} & \multicolumn{3}{|c|}{ Accident Scenario 2} \\
\hline & & & \multirow{2}{*}{$\begin{array}{l}\text { Release } \\
\text { fraction }\end{array}$} & \multicolumn{2}{|c|}{ Release quantities $(\mathrm{Ci})$} & \multirow{2}{*}{$\begin{array}{l}\text { Release } \\
\text { fraction }\end{array}$} & \multicolumn{2}{|c|}{ Release quantities $(\mathrm{C} \mathrm{i})$} \\
\hline Isotope & Max TRU & Max FP & & Max TRU & Max FP & & Max TRU & Max FP \\
\hline${ }^{90} \mathrm{Sr}$ & $2.82 \mathrm{E}+01$ & $3.13 E+03$ & $2.0 \mathrm{E}-07$ & 5.64 E-06 & $6.26 \mathrm{E}-04$ & $2.0 \mathrm{E}-06$ & 5.64 E-05 & $6.26 \mathrm{E}-03$ \\
\hline${ }^{90} \mathrm{Y}$ & $2.82 \mathrm{E}+01$ & $3.13 E+03$ & $2.0 \mathrm{E}-07$ & 5.64 E-06 & $6.26 \mathrm{E}-04$ & $2.0 \mathrm{E}-06$ & 5.64 E-05 & $6.26 E-03$ \\
\hline${ }^{106} \mathrm{Ru}$ & $1.07 \mathrm{E}+01$ & $1.38 E+03$ & $2.7 \mathrm{E}-06$ & $2.88 E-05$ & $3.72 \mathrm{E}-03$ & $4.8 \mathrm{E}-05$ & 5.13 E-04 & $6.62 \mathrm{E}-02$ \\
\hline${ }^{106} \mathrm{Rh}$ & $1.07 E+01$ & $1.38 \mathrm{E}+03$ & $2.0 \mathrm{E}-07$ & 2.14 E-06 & $2.76 \mathrm{E}-04$ & 2.0 E-06 & 2.14 E-05 & $2.76 \mathrm{E}-03$ \\
\hline${ }^{137} \mathrm{Cs}$ & $3.59 \mathrm{E}+01$ & $3.46 E+03$ & $2.0 \mathrm{E}-05$ & $7.18 \mathrm{E}-04$ & $6.92 E-02$ & 2.0 E-04 & $7.18 \mathrm{E}-03$ & 6.92 E-01 \\
\hline${ }^{137} \mathrm{Ba}$ & $3.41 E+01$ & $3.29 E+03$ & $2.0 \mathrm{E}-07$ & 6.82 E-06 & $6.58 \mathrm{E}-04$ & $2.0 \mathrm{E}-06$ & 6.82 E-05 & $6.58 E-03$ \\
\hline${ }^{144} \mathrm{Ce}$ & $9.33 E+01$ & $9.62 E+03$ & 2.0 E-07 & 1.86 E-05 & 1.92 E-03 & $2.0 \mathrm{E}-06$ & $1.86 E-04$ & 1.92 E-02 \\
\hline${ }^{1 * 4} \mathrm{Pr}$ & $9.33 E+0 L$ & $9.62 E+03$ & $2.0 \mathrm{E}-07$ & 1.86 E-05 & 1.92 E-03 & 2.0 E-06 & 1.86 E-04 & 1.92 E-02 \\
\hline${ }^{147} \mathrm{Pm}$ & $6.90 \mathrm{E}+01$ & $7.69 E+03$ & $2.0 \mathrm{E}-07$ & $1.38 \mathrm{E}-05$ & $1.53 \mathrm{E}-03$ & 2.0 E-06 & $1.38 \mathrm{E}-04$ & 1.53 E-02 \\
\hline${ }^{60} \mathrm{Co}$ & $7.24 E+01$ & $4.28 E \div 02$ & 2.0 E-07 & 1.44 E-05 & 8.56 E-05 & $2.0 \mathrm{E}-06$ & 1.44 E-04 & 8.56 E-04 \\
\hline${ }^{85} \mathrm{Kr}^{-}$ & $0.00 E+00$ & $6.28 E+02$ & $3.3 \mathrm{E}-02$ & $0.00 E+00$ & $2.07 \mathrm{E}+01$ & 3.9 E-01 & $0.00 \mathrm{E}+00$ & $2.40 E+02$ \\
\hline${ }^{15 s} \mathrm{Eu}$ & $5.60 E+00$ & $6.40 E+01$ & $2.0 \mathrm{E}-07$ & 1.12 E-06 & $1.28 \mathrm{E}-05$ & 2.0 E-06 & $1.12 \mathrm{E}-05$ & $1.28 \mathrm{E}-04$ \\
\hline${ }^{238} \mathrm{Pu}$ & $3.77 E+01$ & $7.54 E+00$ & 2.0 E-07 & 7.54 E-06 & 1.50 E-06 & $2.0 \mathrm{E}-06$ & 7.54 E-05 & $1.50 \mathrm{E}-05$ \\
\hline${ }^{239} \mathrm{Pu}$ & $6.94 E+01$ & $1.38 E+01$ & 2.0 E-07 & $1.38 \mathrm{E}-05$ & 2.76 E-06 & $2.0 \mathrm{E}-06$ & 1.38 E-04 & 2.76 E-05 \\
\hline${ }^{240} \mathrm{Pu}$ & $1.99 E+02$ & $3.97 E+01$ & 2.0 E-07 & 3.98 E-05 & 7.94 E-06 & 2.0 E-06 & 3.98 E-04 & 7.94 E-05 \\
\hline${ }^{241} \mathrm{Pu}$ & $1.13 E+04$ & $2.27 E+02$ & 2.0 E-07 & $2.26 \mathrm{E}-03$ & 4.54 E-05 & 2.0 E-06 & $2.26 \mathrm{E}-02$ & 4.54 E-04 \\
\hline${ }^{242} \mathrm{Pu}$ & $6.92 E+01$ & 7.08 E-03 & $2.0 \mathrm{E}-07$ & 1.38 E-07 & 1.41 E-09 & 2.0 E-06 & $1.38 E-06$ & 1.41 E-08 \\
\hline${ }^{233} \mathrm{U}$ & $0.00 E+00$ & 1.25 E-01 & 2.0 E -07 & $0.00 E+00$ & $2.50 \mathrm{E}-08$ & 2.0 E-06 & $0.00 E+00$ & 2.50 E-07 \\
\hline${ }^{234} \mathrm{U}$ & $2.07 E+01$ & $1.74 E+00$ & 2.0 E-07 & 4.14 E-06 & 3.48 E-07 & $2.0 \mathrm{E}-06$ & 4.14 E-05 & 3.48 E-06 \\
\hline${ }^{235} \mathrm{U}$ & 2.81 E-04 & $2.64 E-02$ & 2.0 E-07 & 5.62 E-11 & 5.28 E-09 & $2.0 \mathrm{E}-06$ & 5.62 E-10 & 5.28 E-(08 \\
\hline${ }^{236} \mathrm{U}$ & $0.00 E+00$ & 8.42 E-04 & $2.0 \mathrm{E}-07$ & $0.00 E+00$ & $1.68 E-10$ & 2.0 E-06 & $0.00 E+00$ & $1.68 \mathrm{E}-09$ \\
\hline${ }^{238} \mathrm{U}$ & 1.03 E-03 & 3.31 E-04 & $2.0 \mathrm{E}-07$ & 2.06 E-10 & 6.62 E-11 & 2.0 E-06 & 2.06 E-09 & $6.62 \mathrm{E}-10$ \\
\hline
\end{tabular}

FP $=$ Fission product 
Table 10-3. Results of GENII Calculations for Maximum TRU Inventory Case for Accident Scenarios 1 and 2.

\begin{tabular}{|c|c|c|c|c|c|}
\hline $\begin{array}{l}\text { Accident } \\
\text { scenario }\end{array}$ & Receptor & $\begin{array}{l}\text { Exposure } \\
\text { pathway }\end{array}$ & $\begin{array}{l}\text { Effective } \\
\text { dose } \\
\text { equivalent } \\
\text { (rem) }\end{array}$ & $\begin{array}{l}\text { Maximum } \\
\text { exposed } \\
\text { organ }\end{array}$ & $\begin{array}{l}\text { Organ dose } \\
\text { equivalent } \\
\text { (rem) }\end{array}$ \\
\hline \multirow[t]{2}{*}{1} & \multirow[t]{2}{*}{ Onsite } & $\begin{array}{l}\text { Inhalation } \\
\text { Submersion } \\
\text { Subtotal } \\
\text { Plume } \\
\text { meander }\end{array}$ & $\begin{array}{c}3.3 \text { E-01 } \\
3.0 \text { E-06 } \\
3.3 \text { E-01 } \\
4\end{array}$ & \multirow[t]{2}{*}{$\begin{array}{c}\text { Bone } \\
\text { surfaces }\end{array}$} & $\begin{array}{c}3.7 E+00 \\
3.0 E-06 \\
3.7 E+00 \\
4\end{array}$ \\
\hline & & Total & $8.3 E-02$ & & $9.3 \mathrm{E}-01$ \\
\hline \multirow[t]{2}{*}{1} & \multirow[t]{2}{*}{ Offsite } & $\begin{array}{l}\text { Inhalation } \\
\text { Submersion } \\
\text { Ingestion } \\
\text { Deposition } \\
\text { Subtotal } \\
\text { Plume meander }\end{array}$ & $\begin{array}{c}9.4 \mathrm{E}-05 \\
8.8 \mathrm{E}-10 \\
4.3 \mathrm{E}-05 \\
1.4 \mathrm{E}-06 \\
1.4 \mathrm{E}-04 \\
1.2\end{array}$ & \multirow[t]{2}{*}{$\begin{array}{c}\text { Bone } \\
\text { surfaces }\end{array}$} & $\begin{array}{l}1.1 \mathrm{E}-03 \\
8.8 \mathrm{E}-10 \\
1.0 \mathrm{E}-04 \\
1.4 \mathrm{E}-06 \\
1.2 \mathrm{E}-03 \\
1.2\end{array}$ \\
\hline & & Total & $1.1 \mathrm{E}-04$ & & $1.0 \mathrm{E}-03$ \\
\hline \multirow[t]{2}{*}{2} & \multirow[t]{2}{*}{ Onsite } & $\begin{array}{l}\text { Inhalation } \\
\text { Submersion } \\
\text { Subtotal } \\
\text { Plume meander }\end{array}$ & $\begin{array}{c}3.4 E+00 \\
3.1 E-05 \\
3.4 E+00 \\
4\end{array}$ & \multirow[t]{2}{*}{$\begin{array}{c}\text { Bone } \\
\text { surfaces }\end{array}$} & $\begin{array}{c}3.8 E+01 \\
3.1 E-05 \\
3.8 E+01 \\
4 \\
\end{array}$ \\
\hline & & Total & 8.5 E-01 & & $9.5 E+00$ \\
\hline \multirow[t]{2}{*}{2} & \multirow[t]{2}{*}{ Offsite } & $\begin{array}{l}\text { Inhalation } \\
\text { Submersion } \\
\text { Ingestion } \\
\text { Deposition } \\
\text { Subtotal } \\
\text { Plume meander }\end{array}$ & $\begin{array}{c}9.4 \text { E-04 } \\
8.8 \text { E-09 } \\
4.3 \text { E-04 } \\
1.4 \text { E-05 } \\
1.4 \text { E-03 } \\
1.2\end{array}$ & \multirow[t]{2}{*}{$\begin{array}{c}\text { Bone } \\
\text { surfaces }\end{array}$} & $\begin{array}{cc}1.1 & \mathrm{E}-02 \\
8.8 & \mathrm{E}-09 \\
1.0 & \mathrm{E}-03 \\
1.4 & \mathrm{E}-05 \\
1.2 & \mathrm{E}-02 \\
1.2 & \end{array}$ \\
\hline & & Total & $1.2 \mathrm{E}-03$ & & 1.0 E-02 \\
\hline
\end{tabular}

aPlume meander is a correction applied to obtain reported total rem and is calculated using the method described in NRC Regulatory Guide 1.145 (NRC 1982). 
Table 10-4. Results of GENII Calculations for Maximum Fission Product Inventory Case for Accident Scenarios 1 and 2.

\begin{tabular}{|c|c|c|c|c|c|}
\hline $\begin{array}{l}\text { Accident } \\
\text { Scenario }\end{array}$ & Receptor & Exposure pathway & $\begin{array}{l}\text { Effective dose } \\
\text { equivalent (rem) }\end{array}$ & $\begin{array}{c}\text { Maximum } \\
\text { exposed organ }\end{array}$ & $\begin{array}{c}\text { Organ dose } \\
\text { equivalent (rem) }\end{array}$ \\
\hline \multirow[t]{2}{*}{1} & \multirow[t]{2}{*}{ Onsite } & $\begin{array}{l}\text { Inhalation } \\
\text { Submersion } \\
\text { Subtotal } \\
\text { Plume meander }\end{array}$ & $\begin{array}{c}9.4 \text { E-02 } \\
6.6 \text { E-04 } \\
9.5 \text { E-02 } \\
4\end{array}$ & $\begin{array}{l}\text { Bone surfaces } \\
\text { Submersion } \\
\text { Subtotal } \\
\text { Plume meander }\end{array}$ & $\begin{array}{c}4.8 \text { E-01 } \\
6.6 \text { E-04 } \\
4.8 \text { E-01 } \\
4\end{array}$ \\
\hline & & Total & 2.4 E-02 & & $1.2 \mathrm{E}-01$ \\
\hline \multirow[t]{2}{*}{1} & \multirow[t]{2}{*}{ Offsite } & $\begin{array}{l}\text { Inhalation } \\
\text { Submersion } \\
\text { Ingestion } \\
\text { Deposition } \\
\text { Subtotal } \\
\text { Plume meander }\end{array}$ & $\begin{array}{c}2.7 \text { E-05 } \\
1.8 \text { E-07 } \\
3.8 \text { E-03 } \\
1.3 \text { E-04 } \\
4.0 \text { E-03 } \\
1.2 \\
\end{array}$ & $\begin{array}{l}\text { Bone surfaces } \\
\text { LLI } \\
\text { Submersion } \\
\text { Bone surfaces } \\
\text { LLI } \\
\text { Deposition } \\
\text { LLI } \\
\text { Plume meander }\end{array}$ & $\begin{array}{c}1.4 \text { E-04 } \\
9.4 \text { E-06 } \\
1.9 \text { E-07 } \\
4.3 \text { E-03 } \\
4.5 \text { E-03 } \\
1.3 \text { E-04 } \\
4.6 \text { E-03 } \\
1.2\end{array}$ \\
\hline & & Total & 3.3 E-03 & & 3.9 E-03 \\
\hline \multirow[t]{2}{*}{2} & \multirow[t]{2}{*}{ Onsite } & $\begin{array}{l}\text { Inhalation } \\
\text { Submersion } \\
\text { Subtotal } \\
\text { Plume meander }\end{array}$ & $\begin{array}{c}1.1 E+00 \\
7.4 E-03 \\
1.1 E+00 \\
4\end{array}$ & $\begin{array}{l}\text { Lung } \\
\text { Submersion } \\
\text { Subtotal } \\
\text { Plume meander }\end{array}$ & $\begin{array}{c}5.3 E+00 \\
7.4 E-03 \\
5.3 E+00 \\
4\end{array}$ \\
\hline & & Total & $2.8 E-01$ & & \\
\hline \multirow[t]{2}{*}{2} & \multirow[t]{2}{*}{ Offsite } & $\begin{array}{l}\text { Inhalation } \\
\text { Submersion } \\
\text { Ingestion } \\
\text { Deposition } \\
\text { Subtotal } \\
\text { Plume meander }\end{array}$ & $\begin{array}{c}3.1 \mathrm{E}-04 \\
2.1 \mathrm{E}-06 \\
3.8 \mathrm{E}-02 \\
1.3 \mathrm{E}-03 \\
4.0 \mathrm{E}-02 \\
1.2\end{array}$ & $\begin{array}{l}\text { Lung } \\
\text { LLI } \\
\text { Submersion } \\
\text { Lung } \\
\text { LLI } \\
\text { Deposition } \\
\text { LLI } \\
\text { Plume meander }\end{array}$ & 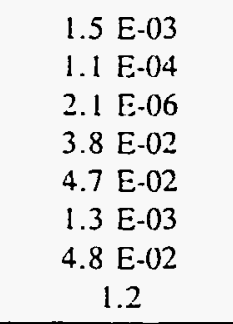 \\
\hline & & Total & 3.3 E-02 & & 4.0 E-02 \\
\hline
\end{tabular}

sPlume meander is a correction applied to obtain the reported total rem and is calculated using the method described in NRC Regulatory Guide 1.145 (NRC 1982). Total equals the greater of the sums of the bone surtace or lung doses for accident scenario 1, and the greater of the sums of the lung or large lower intestine (LLI) dose for scenario 2 (corrected for plume meander). 


\subsection{REFERENCES}

Atherton, R., E. J. Kikta, and J. Sherman, 1968, PWR Core 2 Design Description Report, WARD-296, Bettis Atomic Power Laboratory, West Mifflin, Pennsylvania.

Conway, 1994, Defense Nuclear Facility Safety Board Recommendation 94-1, (letter to H. R. O'Leary, U.S. Secretary of Energy, dated May 26), Defense Nuclear Facility Safety Board, Washington, D.C.

DOE, 1993, Spent Fuel Working Group Report on Inventory and Storage of the Department's Spent Nuclear Fuel and Other Reactor Irradiated Nuclear Materials and Their Environmental, Safety, and Health Vulnerabilities, Vol. 1, U.S. Department of Energy, Washington, D.C.

DOE-RL, 1983, Operation of PUREX and Uranium Oxide Plant Facilities Environmental Impact Statement, DOE-EIS-0089, U.S. Department of Energy Richland Operations, Richland, Washington.

DOE-RL, 1991, Calendar Year 1990 Air Emissions Report for the Hanford Site, DOE/RL-91-10, U.S. Department of Energy Richland Operations, Richland, Washington.

DOE-RL, 1992, Radionuclide Air Emissions Report for the Hanford Site Calendar Year 1991, DOE/RL-92-30, U.S. Department of Energy Richland Operations. Richland, Washington.

DOE-RL, 1993a, Application for Approval of Modification for the 105-KE Basin Encapsulation Activity, DOE/RL-93-14, U.S. Department of Energy Richland Operations, Richland, Washington.

DOE-RL, 1993b, Radionuclide Air Emissions Report for the Hanford Site Calendar Year 1992, DOE/RL-93-36, U.S. Department of Energy Richland Operations, Richland, Washington.

Ecology, EPA, and DOE, 1994, Hanford Federal Facility Agreement and Consent Order, as amended, Washington State Department of Ecology, U.S. Environmental Protection Agency, and U.S. Department of Energy, Olympia, Washington. 
HEDL, 1985, Postirradiation Testing Laboratory (327 Building) Safety Analysis Report, HEDL-TC-1009, Westinghouse Hanford Company, Richland, Washington.

Hunter, J. R., 1993, Termination of the Plutonium-Uranium Extraction (PUREX) Plant and Guidance to Proceed with Shutdown Planning and Terminal Cleanout Activities, (Letter to T. M. Anderson, Westinghouse Hanford Company, dated January 11), U.S. Department of Energy Richland Operations, Richland, Washington.

Gydesen, C. H., 1975; Functional Design Criteria Supplemental N-Reactor Fuel Storage 105-KW, UNI-410, Rev. 0, United Nuclear Industries, Inc., Richland, Washington.

Gydesen, C.H., 1977, Functional Design Criteria Supplemental N-Reactor Irradiated Fuel Storage, 105-KE, UNI-108, Rev. 3, United Nuclear Industries, Inc., Richland, Washington.

Lanning, D. D., 1992, Discussion and Requirements on T-Plant Chiller-Off Test, (Letter to D. C. Hedengren, Westinghouse Hanford Company, November 9), Pacific Northwest Laboratory, Richland, Washington.

NRC, 1982, Atmospheric Dispersion Models for Potential Accident Consequences at Nuclear Power Plants, Regulatory Guide 1.145, U.S. Nuclear Regulatory Commission. Washington, D.C.

PNL, 1992a, Safety Analysis Report for the 325 Building, PNL-7748 Draft, Pacific Northwest Laboratory, Richland, Washington.

PNL, 1992b, Safety Analysis Report for 324 Building Waste Technology, Engineering Laboratory, PNL-7989, Pacific Northwest Laboratory, Richland, Washington.

PNL, 1993a, Pacific Northwest Laboratory ALARA Report for CY 1992, PNL-8849. Pacific Northwest Laboratory, Richland, Washington.

PNL, 1993b, Safety Analysis, PNL-MA-44, Pacific Northwest Laboratory, Richland, Washington.

RHO, 1978a, PWR Core 2 Project Accident Analysis, RHO-CD-296, Rockwell Hanford Operations, Richland, Washington.

RHO, 1978b, Safety Assessment Document - PWR Core II Project, RHO-CD-365 Rev. 0, Rockwell Hanford Operations, Richland, Washington. 
Smith, G. L., 1991, Consequence Analyses of Hypothetical K-Basin Accident Scenarios, (Internal Memorandum to J. P. Schmidt, August 14), Westinghouse Hanford Company, Richland, Washington.

Van Keuren, J., 1994, FSF Source Term for Spent Fuel EIS (Internal memorandum to K. H. Bergsman), Westinghouse Hanford Company, Richland, Washington.

WHC, 1989, Fuel Storage Facility Final Safety Analysis Report, WHC-EP-0132, Westinghouse Hanford Company, Richland, Washington.

WHC, 1990, 308 Building Final Safety Analysis Report, WHC-SD-FL-SAR-002, Westinghouse Hanford Company, Richland, Washington.

WHC, 1991a, ALARA Plan for Repackaging and Fuel Encapsulation at 105-KE Basin, WHC-SD-NR-PLN-007, Rev. 0, Westinghouse Hanford Company, Richland, Washington.

WHC, 1991b, An Assessment of Potential Radiological Doses from Overflow at a $100 \mathrm{~K}$ Fuel Storage Basin, WHC-SD-NR-TA-011, Rev. 0, Westinghouse Hanford Company, Richland, Washington.

WHC, 1991c, Facility Effluent Monitoring Plan Determinations for the 100 Area Facilities, WHC-EP-0439, Westinghouse Hantord Company, Richland, Washington.

WHC, 1992a, Engineering Study Sludge Handling System 100-K Water Supply and Distribution, WHC-SD-N027-ER-001, Rev. 0, Kaiser Engineers Hanford Company for Westinghouse Hanford Company, Richland, Washington.

WHC, 1992b, Retrievable Storage of Irradiated Fuels in the Solid Waste Burial Grounds, WHC-SD-WM-SAR-047, Westinghouse Hanford Company, Richland, Washington.

WHC, 1992c, Safety Evaluation of Fuel Encapsulation in the 105-KE Storage Basin, WHC-SD-NR-TA-020, Rev. 0, Westinghouse Hanford Company, Richland, Washington.

WHC, 1993a, Engineering Study of the Transfer of Irradiated Fuels on the Hanford Site, WHC-SD-TP-ES-001, Rev. 0, Westinghouse Hanford Company, Richland, Washington.

WHC, 1993b, Environmental Releases for Calendar Year 1992, WHC-EP-0527-2, Westinghouse Hanford Company, Richland, Washington. 
WHC, 1993c, Hanford Site Stored Spent Nuclear Fuel Vulnerability Assessments, WHC-SD-WM-ANAL-025, Westinghouse Hanford Company, Richland, Washington.

WHC, 1993d, Safety Analysis Irradiated N Reactor Fuel, WHC-SD-WM-SAR-062, Rev. 0, Westinghouse Hanford Company, Richland, Washington.

WHC, 1993e, T Plant Safety Analysis Report, WHC-SD-CP-SAR-007, Rev. 1, Westinghouse Hanford Company, Richland, Washington.

WHC, 1993f, Transport Mechanism of Radionuclides in 105-KE Fuel Storage Basin to Airborne Effluent Release, WHC-SD-NR-ES-016, Columbia Energy and Environmental Services, Inc. for Westinghouse Hanford Company, Richland, Washington.

WHC, 1994a, Evaluation of the Option of Dry Storage of Shippingport Core II Spent Blanket Assemblies in T-Plant, WHC-SD-WM-ES-289, Westinghouse Hanford Company, Richland, Washington.

WHC, 1994b, FFTF Shutdown Program Plan, WHC-SD-FF-SSP-004, Rev. 0, Westinghouse Hanford Company, Richland, Washington.

WHC, 1994c, Hanford Irradiated Fuel Inventory Baseline, WHC-SD-SNF-TI-001, Rev. 0, Westinghouse Hanford Company, Richland, Washington.

WHC, 1994d, Interim Safety Basis for the 308 Building, WHC-SD-FL-ISB-001, Rev. 0, Westinghouse Hanford Company, Richland, Washington.

WHC, 1994e, Post Seismic Leakage, UO RL-WHC-KBASINS-1994-007, Westinghouse Hanford Company, Richland, Washington.

WHC, 1994f, Test Report-100 K Airflow Effluent Volume Test, 1993 , WHC-SD-NR-TRP-019, Westinghouse Hanford Company, Richland, Washington.

WHC-CM-1-6, WHC Radiological Control Manual, Westinghouse Hanford Company, Richland, Washington.

WHC-CM-7-5, WHC Environmental Compliance Manual, Westinghouse Hanford Company, Richland, Washington. 